\author{
UNIVERSIDADE DE BRASÍLIA \\ CIÊNCIAS E TECNOLOGIAS EM SAÚDE \\ FACULDADE DE CEILÂNDIA
}

\title{
ESTUDO DA INFLUÊNCIA DA MORFOLOGIA DE NANOPARTÍCULAS DE SÍLICA MESOPOROSA NA LIBERAÇÃO DO ANTICANCERÍGENO INDOL-3-CARBINOL.
}

\author{
VICTOR BRAGA COELHO VIEIRA
}

ORIENTADOR: DR. JULIANO ALEXANDRE CHAKER

BRASÍLIA-DF 


\author{
UNIVERSIDADE DE BRASÍLIA \\ CIÊNCIAS E TECNOLOGIAS EM SAÚDE \\ FACULDADE DE CEILÂNDIA
}

\title{
ESTUDO DA INFLUÊNCIA DA MORFOLOGIA DE NANOPARTÍCULAS MESOPOROSAS DE SILICATOS NA LIBERAÇÃO DO ANTICANCERÍGENO INDOL-3-CARBINOL.
}

VICTOR BRAGA COELHO VIEIRA

\begin{abstract}
Dissertação apresentada à Faculdade de Ceilândia da Universidade de Brasília como requisito parcial para obtenção do título de Mestre em Ciências e Tecnologias em Saúde.
\end{abstract}

ORIENTADOR: DR. JULIANO ALEXANDRE CHAKER

BRASÍLIA-DF 


\title{
MEMBROS DA BANCA
}

A presente dissertação, intitulada "ESTUDO DA INFLUÊNCIA DA MORFOLOGIA DE NANOPARTÍCULAS MESOPOROSAS DE SILICATOS NA LIBERAÇÃO DO ANTICANCERÍGENO INDOL-3-CARBINOL", com autoria de Victor Braga Coelho Viera, foi apresentada no dia 24 de julho de 2015 como requisito parcial para obtenção do título de Mestre em Ciências e Tecnologia em Saúde. A banca avaliadora foi formada por:

\author{
Prof. Dr. Juliano Alexandre Chaker. (presidente) \\ Faculdade de Ceilândia da Universidade de Brasília- UNB \\ Programa de Pós-Graduação em Ciências e Tecnologias em Saúde
}
Prof. Dr. José Antonio Huamani Coaquira
Universidade de Brasília - UNB
Avaliador Externo

Prof. Dr. Marcelo Henrique Sousa

Faculdade de Ceilândia da Universidade de Brasília - UNB

Programa de Pós-Graduação em Ciências e Tecnologias em Saúde

Prof. Dr. Graziella Anselmo Joanitti

Faculdade de Ceilândia da Universidade de Brasília- UNB

Programa de Pós-Graduação em Ciências e Tecnologias em Saúde Avaliador Suplente 


\section{AGRADECIMENTOS}

Agradeço principalmente a minha família, ao meu pai Jorge Vieira e minha mãe Maria Isabel Braga Coelho que sempre apoioram nos meus objetivos, através do amor e educação que me dedicaram.

A minha filha Ana Clara A. Coelho pelo carinho, compreensão e por me fazer lembrar o quanto sua existência torna minha vida especial.

Aos meus irmãos e sobrinhos (as) pela inspiração e exemplo de vida que me proporcionam.

Ao professor, amigo e orientador Juliano Alexandre Chaker pela oportunidade, orientação, paciência e empenho para esclarecer dúvidas e auxiliar na elaboração deste trabalho.

Ao Professor Marcelo Henrique pela colaboração e contribuições para a realização deste trabalho.

Ao professor José Antonio Coaquira pela colaboração e por me disponibilizar o uso de equipamentos do laboratório de Física para a execução da metodologia deste trabalho.

Ao professor José Dias pela colaboração e prontidão em esclarecer dúvidas e da execução das medidas de BET.

Ao professor Jorlândio por toda ajuda e auxilio na execução de técnicas de EPR e raios $X$ rasante, medidas fundamentais para $O$ esclarecimento dos matérias obtidos nesse trabalho.

Ao amigo e companheiro de mestrado Mac Kedson por estar sempre prestativo e pela ajuda na execução deste trabalho.

Aos técnicos de laboratório pela assistência com os experimentos realizados.

A todos os meus amigos que sempre me incentivaram desde o início dessa caminhada.

A CAPES pelo apoio financeiro através da bolsa de Mestrado que me foi comtemplada. 
Dedico este trabalho a força criadora do universo, a minha familia e a todos que me apoiaram de forma direta ou indireta. 
"Quem vence alguém é vencedor, e quem vence a si mesmo é invencível" 


\section{SUMÁRIO}

\section{Sumário}

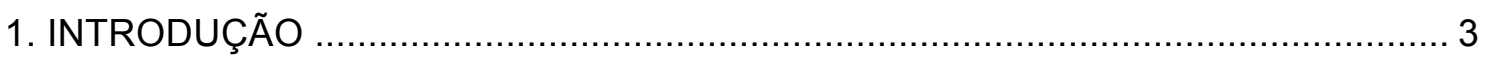

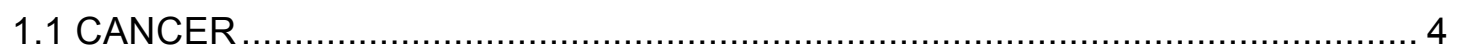

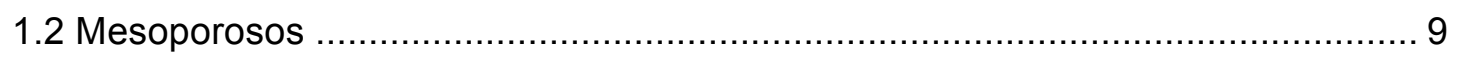

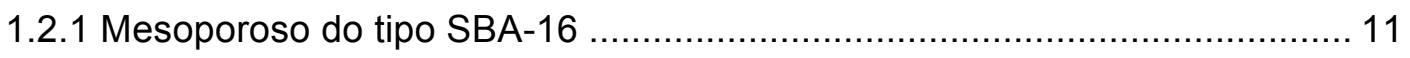

1.2.2 Métodos de Síntese (o processo sol-gel) ......................................... 12

1.2.3 Mecanismos de síntese do SBA-16 .................................................. 14

1.2.4 O agente direcionador de estrutura Pluronic F-127 ............................. 15

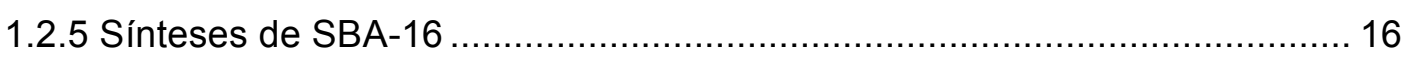

1.2.6 Remoção do surfactante .............................................................. 17

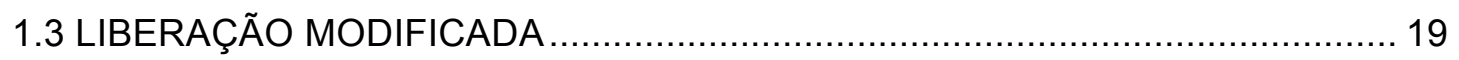

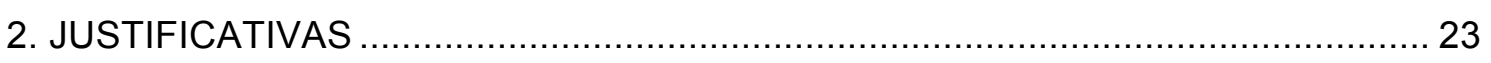

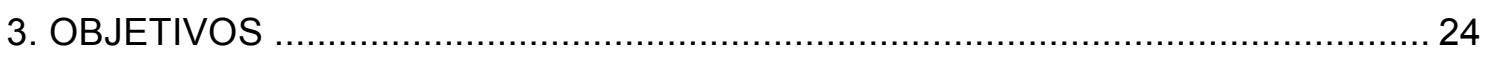

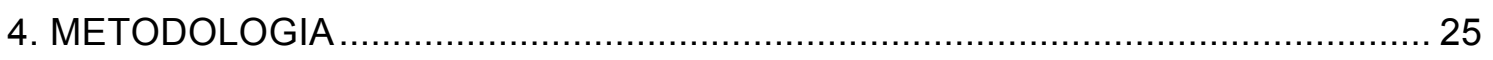

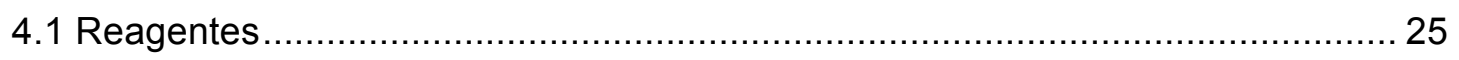

4.2 Preparação das partículas mesoporosas ....................................................... 26

4.4 Estudo da remoção do surfactante .......................................................... 27

4.3 Impregnação das partículas mesoporosas com Indol-3-carbinol ........................ 28

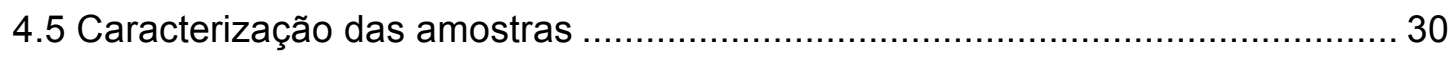

4.5.1 Espectroscopia de Absorção na Região do Infravermelho por transformada

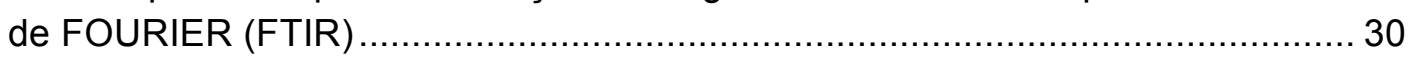

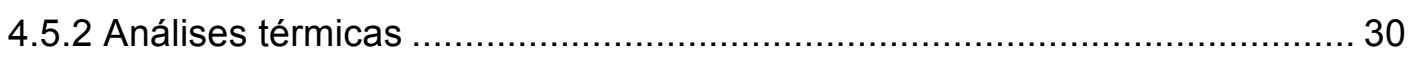

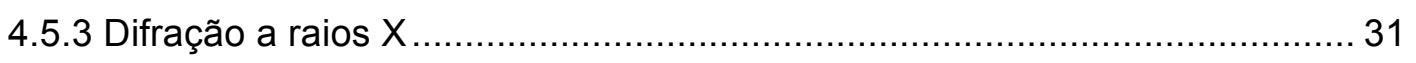

4.5.4 Adsorção e Dessorção de Nitrogênio...................................................... 32

4.5.5 Microscopia Eletrônica de Varredura (MEV) ........................................... 34

4.5.6 Microscopia eletrônica de transmissão (MET) …..................................... 34

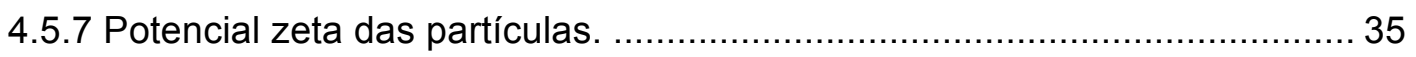

4.5.8 Espectroscopia de ressonância paramagnética eletrônica (EPR) …............ 35

4.5.9 Espectroscopia no ultravioleta visível (UV/Vis) ...................................... 35

5. Apresentação do resultados e discussões segue a seguinte forma: ........................ 36

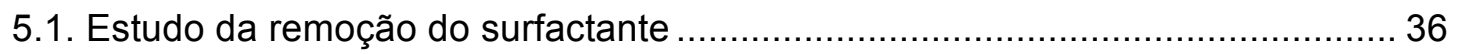

5.2 Do ordenamento, morfologia e carga de superfície dos poros. ........................ 49 


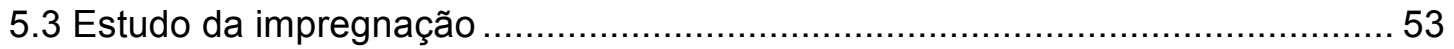

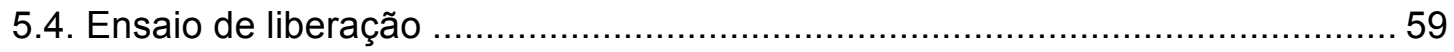

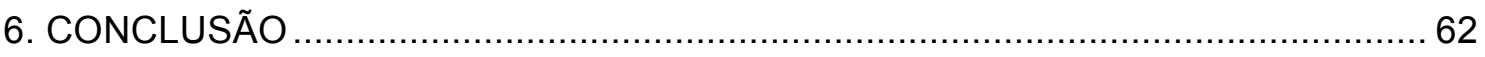

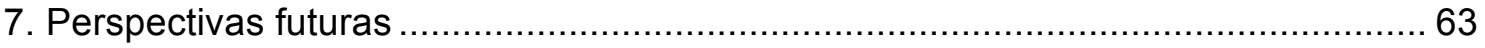

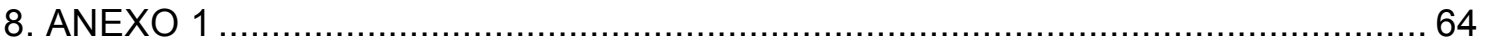

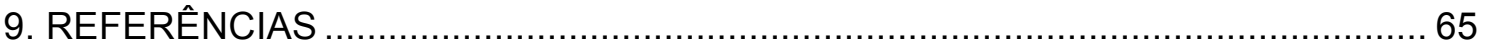




\section{LISTA DE ABREVIAÇÕES E SÍMBOLOS}

a0 - Parâmetro de Célula Unitária para a Rede Cúbica

APTES - 3-aminopropiltrietoxisilano

ADEs -agentes direcionadores de estrutura

A -Angstrom

BET - Brunauer-Emmet-Teller

BJH - Barrett-Joyner-Halenda

CDK6 cyclin-dependent kinase 6

CTMABr Brometo de cetiltrimetilamônio

d(110) Espaçamento Interlunar entre os Planos 110

DMSO dimetilsulfóxido

Dp- Diâmetro de Poros Calculado

DNA ácido desoxirribonucleico

Era Receptores de estrogênio

EO106-PO70-EO106 Formula do pluronic 127

FTIR - Fourier Transform Infrared Spectroscopy (Espectroscopia na Região do Infravermelho com Transformada de Fourier)

HRTEM high -resolution transmission electron microscopy (microscópica de transmissão eletrônica de alta resolução).

hTERT human telomerase reverse transcriptase

I3C Indole-3-carbinol

IGF1R Insulin-like growth factor 1 receptor)

IRS1 Insulin receptor substrate 1

(I+) representa os precursores inorgânicos catiônicos

(I-) representa os precursores inorgânicos aniônicos

IC50 - concentração do composto que produziu 50\% de morte celular

IUPAC - International Union of Pure and Applied Chemistry

$\mathrm{KBr}$ - Brometo de sódio

LCT - Liquid Crystal Templating (Mecanismo de Direcionamento por Cristal Líquido) 
I3C - Indol-3-carbinol

MCF-7 - Adenocarcinoma mamário humano

MCM-41 - Mobil Composition of Matter Number 41

MCM-48 - Mobil Composition of Matter Number 48

M41S Família de materiais mesoporosos que agrega a MCM-41, MCM-48 e MCM-50 Mobil Composition of Matter Number 50

MET - Microscopia Eletrônica de Transmissão

MEV - Microscopia Eletrônica de Varredura

NaAc-HAc Solução tampão

P/P0 - Pressão Relativa

P123 - Pluronic 123 - poli(óxido de etileno)20-poli(óxido de propileno)70poli(óxido de etileno)20

P127 - Pluronic 127 - poli(óxido de etileno)106-poli(óxido de propileno)70poli(óxido de etileno)106

PEO - Poli(óxido de etileno)

PPO - Poli(óxido de propileno)

$(\mathrm{S}+)$ representa o surfactante catiônico

(S-) representa o surfactante aniônico 10

SBA Santa Barbara

SBA-1 - Santa Barbara Amorphous Number 1

SBA-11 - Santa Barbara Amorphous Number 11

SBA-12 - Santa Barbara Amorphous Number 12

SBA-14 - Santa Barbara Amorphous Number 14

SBA-15 - Santa Barbara Amorphous Number 15

SBA-16 - Santa Barbara Amorphous Number 16

SBET - Área Superficial Específica Calculada pelo Método

SDS Dodecil sulfonato surfactante de sódio

St - Área Superficial Total

TEOS - Tetraetilortossilicato

TG - Termogravimetria ou Análise Termogravimétrica

UV-VIS - Ultravioleta - Visível

Vmeso1 - Volume de Mesoporos Primários

$(\mathrm{X}+)$ representa os contra-íons catiônicos 
(X-) representa os contra-íons aniônicos

DRX Difratometria de raios $X$ 


\section{LISTA DE FIGURAS}

Figura 1 Processo de desenvolvimento das células cancerígenas...................4

Figura 2 Estrutura molecular do indole-3-carbinol......................................

Figura 3 Mecanismo de formação de materiais mesoporosos por um

surfactante: 1) fase cristal líquido inicial 2) Interação do silicato com o

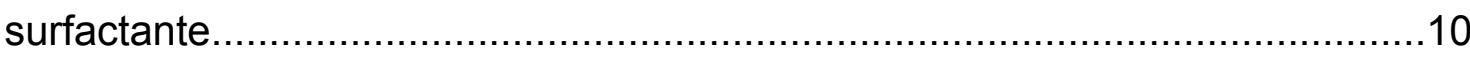

Figura 4 Mesoporosos do tipo M41S. ................................................ 11

Figura 5 Mesoporoso cúbico do tipo SBA-16........................................12

Figura 6 Esquema ilustrativo da gelatinização/reticulação do sistema

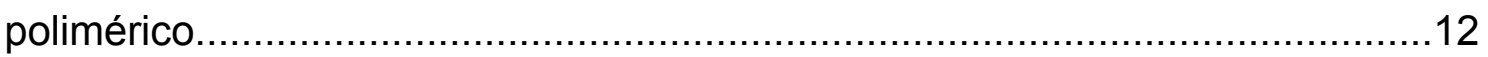

Figura 7 Representação do esquema do método da SBA-16 .......................14

Figura 8 Formação de micelas isoladas e michelas agregadas......................15

Figura 9 Estrutura química do Pluronic F127......................................... 16

Figura 10 Representação esquemática da desidratação da micela com o

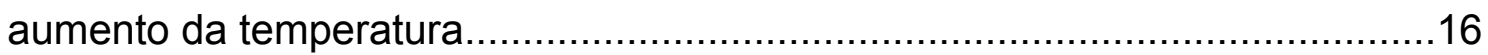

Figura 11 llustração da estrutura do mesoporoso SBA-15 após o tratamento térmico por calcinação.

Figura 12 Níveis plasmáticos do principio ativo de um sistema convencional, comparado com um sistema de liberação sustentada...................................20

Figura 13 Orgonograma da metodologia de síntese e tratamento do térmico dos materiais mesoporosos.

Figura 14 Orgonograma da metodologia de impregnação dos materiais mesoporosos com indol-3-carbinol.

Figura 15 Classificação das isotermas de adsorção/ dessorção de nitrogênio.33

Figura 16 Tipos de histeres.

Figura 17 (a) Curva de espectroscopia no infravermelho do pluronic 127. (b)

Estrutura química do P127. (c) Grupos funcionais do P127...

Figura 18 Curva de espectroscopia no infravermelho das amostras com extração sob refluxo em meio etanol/ $\mathrm{Hcl}$ e calcinadas a $350^{\circ} \mathrm{C}$ por 4 horas.....38 Figura 19 Curvas de DSC do pluronic e das amostras lavadas sob refluxo em meio etanol $/ \mathrm{Hcl}$ sob uma razão de aquecimento de $20^{\circ} \mathrm{C} \cdot \mathrm{min}^{-1}$, em atmosfera inerte de nitrogênio a $20 \mathrm{~mL} \cdot \mathrm{min}^{-1}$, até uma temperatura de $350^{\circ} \mathrm{C}$ 
Figura 20 Espectros de absorção na região do infravermelho de amostras T100 submetidas à diferentes métodos de remoção do surfactante.

Figura 21 Difratogramas de raios $X$ de amostra T100 submetidas a lavagem sob refluxo $\mathrm{HCl} /$ etanol e tratadas termicamente em diferentes temperaturas...42 Figura 22 Isotermas de adsorção/dessorção das amostras calcinadas em diferentes temperaturas. (a) $305^{\circ} \mathrm{C}$, (b) $450^{\circ} \mathrm{C}$ e (c) $550^{\circ} \mathrm{C}$.

Figura 23 Curvas de espectroscopia no infravermelho das amostras estudados tratadas termicamente a $350^{\circ} \mathrm{C}$ por 10 horas. 45

Figura 24 Difratogramas de raios $X$ das fontes de sílica calcinada em à $350^{\circ} \mathrm{C}$ por 10 horas

Figura 25 Curvas de isotermas dos materiais mesoporosos calcinados a $350^{\circ} \mathrm{C}$ por 10 horas. .46

Figura 26 curva da área de superfície em função das concentrações de 0\%, $12 \%, 50 \%, 88 \%$ e $100 \%$ de TEOS.

Figura 27 Curva do raio dos poros em função das concentrações de 0\%, 12\%, $50 \%, 88 \%$ e $100 \%$ de TEOS.

Figura 28 Curva de difratogramas de raios $X$ a baixo angulo das amostras calcinadas a $350^{\circ} \mathrm{C}$ por 10 horas.

Figura 29 Imagem de microscopia eletrônica de transmissão dos silicatos de mesoporosos em uma escala de 10 nanômetros.

Figura 30 Gráfico referente a composição dos silicatos estudos por microscopia eletrônica de transmissão.

Figura 31 Imagem de microscopia eletrônica de varredura da amostras T0, T50 e T100.

Figura 32 Imagem de microscopia eletrônica de varredura das amostras T0, T88 e T100

Figura 33 Curvas das cargas de superfícies das amostras com 0\%, 12\%, 50\%

e $100 \%$ de TEOS calcinadas à $350^{\circ} \mathrm{C}$ por 10 horas.

Figura 34 curva de espectrometria de infravermelho do fitoquimico indol-3carbinol (a). Bandas de absorção dos espectro de infravermelho (b). Estrutura química do índole-3-carbinol (c).

Figura 35 curva de espectrometria de infravermelho da amostra T0, T12, T50 pura em comparação com a amostra T0, T12, T50 impregnadas com indol-3carbinol. 
Figura 36 curva de espectrometria de infravermelho da amostra T88 pura em comparação com a amostra T88 impregnada com indol-3-carbinol .56 Figura 37 Curva de espectrometria de infravermelho da amostra T100 pura em comparação com a amostra T100 impregnada com indol-3-carbinol. 56

Figura 38 Espectros de ressonância paramagnética eletrônica das amostras $\mathrm{T} 0, \mathrm{~T} 12, \mathrm{~T} 88$ e $\mathrm{T} 100$ calcinadas a $350^{\circ} \mathrm{C}$ por 10 horas e calcinadas e impregnadas com $13 \mathrm{C}$ sob agitação por 45 horas. .57 Figura 39 Mostra a curva de calibração obtida a partir de diluições seriadas da solução estoque de I3C em concentração conhecida de $0,001 \mathrm{mg} / \mathrm{ml}$.. .59 Figura 40 Ensaios de liberação de amostras impregnadas com diferentes porosidades. 


\section{LISTA DE TABELAS}

Tabela 1 Dos principais agentes neoplásicos utilizados na clínica médica..........5

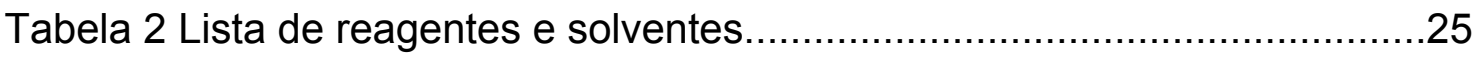

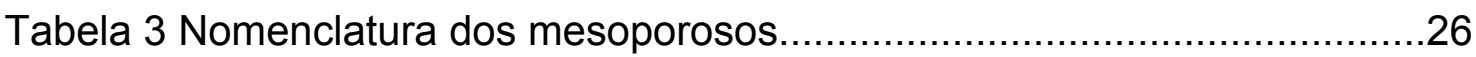

Tabela 4 Temperatura e tempo de calcinação utilizado nos tratamento

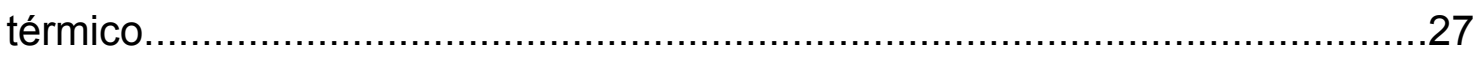

Tabela 5 Nomenclatura da sílicas calcinadas à $350^{\circ} \mathrm{C}$ por 10 horas e

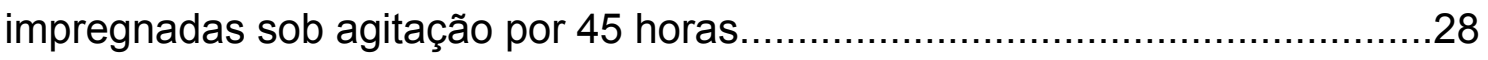

Tabela 6 Comparação de diferentes temperaturas em função do tempo...........40

Tabela 7 Identificação espectrofotométrica de grupos funcionais......................41

Tabela 8 Resultados do Bet em relação a temperatura e fechamento dos

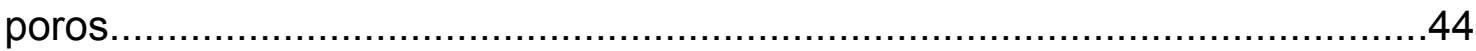

Tabela 9 Resultados da adsorção/dessorção das amostras calcinadas a 350C

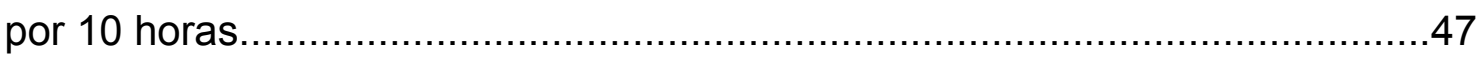

Tabela 10 Valores do diâmetro e espessura da parede dos poros das amostras

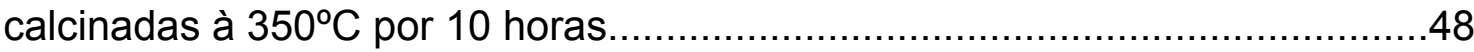

Tabela 11 Estimativa da massa total de indol-3-carbinol contida no mesoporoso. 


\section{LISTA DE ANEXO}

Anexo 1 Revisão bibliográfica para o estudo da remoção do surfactante. 


\section{RESUMO}

No último século, o câncer se tornou uma das principais causas de morte no mundo. Os tratamentos frequentemente utilizados no tratamento podem causar vários efeitos colaterais, complicações decorrentes e até a morte do paciente. No entanto, o bioativo Indol-3-carbinol (I3C) tem demonstrado efeitos preventivos e antineoplásicos promissores. Considerando a necessidade do incremento nos métodos do tratamento oncológico, o aumento da eficiência e diminuição dos efeitos colaterais dos tratamentos atualmente existentes, este trabalho visa impregnar nanopartículas mesoporosas e correlacionar a liberação do ativo $\mathrm{I3C}$ com as diferentes porosidades dos materiais mesoporosos obtidos. Esses materiais foram analisados, quanto a impregnação e liberação, e caracterizados por espectrometria de infravermelho por transformada de FOURIER (FTIR), calorimetria exploratória diferencial (DSC), difração de raios $X$, difração de raios $X$ a ângulos rasantes, adsorção/dessorção de nitrogênio, medidas de potencial ZETA, ressonância paramagnética eletrônica (EPR), UV-vis e microscopia de transmissão e varredura. Por meio da técnica de FTIR, foi possível observar bandas de absorção referente as sílicas, a ausência do surfactante e a presença do I3C. Os dados obtidos pelo FTIR e DSC mostraram que a remoção do surfactante depende da temperatura utilizada no tratamento térmico. A difração de raios $X$ e BET apontaram no tratamento térmico das amostras, que temperaturas superiores a $450^{\circ} \mathrm{C}$ causaram a cristalinidade e diminuição da porosidade dos óxidos de sílicio, respectivamente. A técnica de EPR revelou a impregnação do I3C nas redes de sílica, através da diminuição dos pontos de defeito nas amostras impregnadas. As medidas de difração de raios $X$ a ângulos rasantes evidenciaram um mesoporoso do tipo SBA-16 de estrutura cúbica de corpo centrado $\mathrm{Im} 3 \mathrm{~m}$. Com esses resultados pode se concluir que quanto maior concentração de TEOS, usado na síntese dos mesoporosos, menor a porosidade dos materiais obtidos e que esses parâmetros exerceram uma influência direta na liberação do principio ativo I3C, medidos no UV-vis.

Palavras chaves: Materiais mesoporosos, sílica mesoporosa do tipo SBA-16, indol-3-carbinol e perfil de liberação. 


\section{ABSTRACT}

Over the last century, cancer became a leading cause of death worldwide. The treatments often used in the treatment can cause various side effects, complications and even death of the patient. However, Indole-3-carbinol bioactive (I3C) has demonstrated promising anticancer and preventive effects. Considering the need of the increase in the methods of cancer treatment, increased efficiency and reduction of side effects of currently available treatments, this work aims to impregnate mesoporous nanoparticles and to correlate the release of the active I3C with the different porosities of mesoporous materials obtained. These materials were analyzed, as impregnation and release, and characterized by infrared of spectroscopy (FITR), differential scanning calorimetry (DSC), X-ray diffraction, X-ray diffraction at small angles, adsorption / desorption of nitrogen, ZETA potential, electron paramagnetic resonance (EPR), UV-Vis and transmission microscopy and scanning. Through FITR technique, it was possible to observe absorption bands relating silicas, the absence of surfactant, and the presence of $13 \mathrm{C}$. The FITR and data obtained by DSC showed that removal of the surfactant depends on the temperature used in the heat treatment. The diffraction X-ray and BET showed the thermal treatment of samples, that temperatures above $450^{\circ} \mathrm{C}$ caused the crystallinity and decrease the porosity of the sand oxides, respectively. The EPR technique revealed the impregnation of $\mathrm{I} 3 \mathrm{C}$ in silica networks, by lowering the defect points in the impregnated samples. Measures to X-ray diffraction to grazing angles shown a mesoporous SBA-16 cubic structure type body centered $\operatorname{Im} 3 \mathrm{~m}$. With these results it can be concluded that the higher concentration of TEOS used in the synthesis of mesoporous, lower porosity of the obtained materials and that these parameters exert a direct influence on the release of the active principle I3C measured UV-vis.

Keywords: Mesoporous materials, SBA-16-type mesoporous sílica, indol-3carbinol, profile of release. 


\section{INTRODUÇÃO}

Atualmente materiais nanotecnológicos com capacidade de armazenar, transportar e entregar drogas vêm sendo cada vez mais estudados, dentre eles, encontram-se os óxidos de silícios mesoporosos. Estes materiais, apresentam diversas vantagens devido a uma elevada área superficial, porosidade entre 20 e $300 \AA$, largas espessuras nas paredes e uma alta estabilidade térmica. Tais características, contribuem para proporcionar sítios ativos bem distribuídos, gerando também uma ótima atividade catalítica, adsortiva e em uma matriz capaz de entregar e controlar a liberação de ativos.

Dentre a diversidade de materiais mesoporosos desenvolvidos, podem-se citar a SBA-16, de estruturas ordenada e excelentes propriedades porosimetricas e de grande interesse no tratamento de doenças, como por exemplo, o câncer. O Instituto Nacional do Câncer reconhece que o uso da nanotecnologia aplicado à oncologia tem potencial para revolucionar a medicina moderna na detecção, tratamento e prevenção do câncer (INCA, 2012). Devido as diversas barreiras fisiológicas e efeitos colaterais adversos do tratamento do câncer, a união da bionanotecnologia com bioativos derivados de vegetais estão sendo amplamente utilizados. Alguns princípios ativos como curcumina, resveratrol, genisteína, daidzeína, epigalocatequina, quercitina, e indol-3-carbinol, mostraram-se efetivos na incorporação e liberação controlada a partir de matrizes de nanotecnologia (HAREESH, 2010).

Neste trabalho, inicialmente serão explicitados uma revisão de literatura abordando aspectos sobre o câncer, os óxidos de silício de mesoporosos utilizados no tratamento da doença e e o potencial de aplicação destes sistemas como dispositivos para liberação controlada de fármacos. A seguir, são demonstrados as justificativas e os objetivos que levaram ao desenvolvimento deste trabalho. $O$ próximo tópico descreve os detalhes experimentais e as metodologias utilizadas neste trabalho, bem como as técnicas utilizadas para a caracterização dos materiais e para a liberação sustentada. Os principais resultados são apresentados e discutidos em seguida. Por fim, algumas conclusões e perspectivas futuras são consideradas. 


\subsection{CANCER}

Durante o último século, o câncer se tornou uma das principais causas de morte no mundo. O impacto global dessa patologia mais que dobrou nos últimos 30 anos. Desde então, os tumores de células malignas têm sido estudados em diferentes aspectos e sua cura permanece como o maior paradigma médico-científico já estabelecido. No Brasil, de acordo com estimativas do Instituto Nacional do Câncer (INCA), em 2012, a epidemiologia da doença segue a tendência mundial (INCA, 2012).

O cancro é um tecido complexo formado por diferentes tipos células com mutações no material genético caracterizado por desordens celulares. As principais causas das mutações que ocorrem no DNA estão relacionadas aos fatores genéticos, epigenéticos e/ou ambientais (HANAHAN \& WINBERG 2011). Portanto, o câncer é uma doença com múltiplos processos relacionados com os sistemas fisiológicos celulares, tais como sinalização celular, apoptose, barreira fisiológica nos poros vasculares endoteliais, fornecimento de sangue heterogêneo, entre outros (WANG, 2008; PATIL, 2010; MISRA, 2010).

As características do processo de desenvolvimento cancerígeno estão representadas na Figura 1.

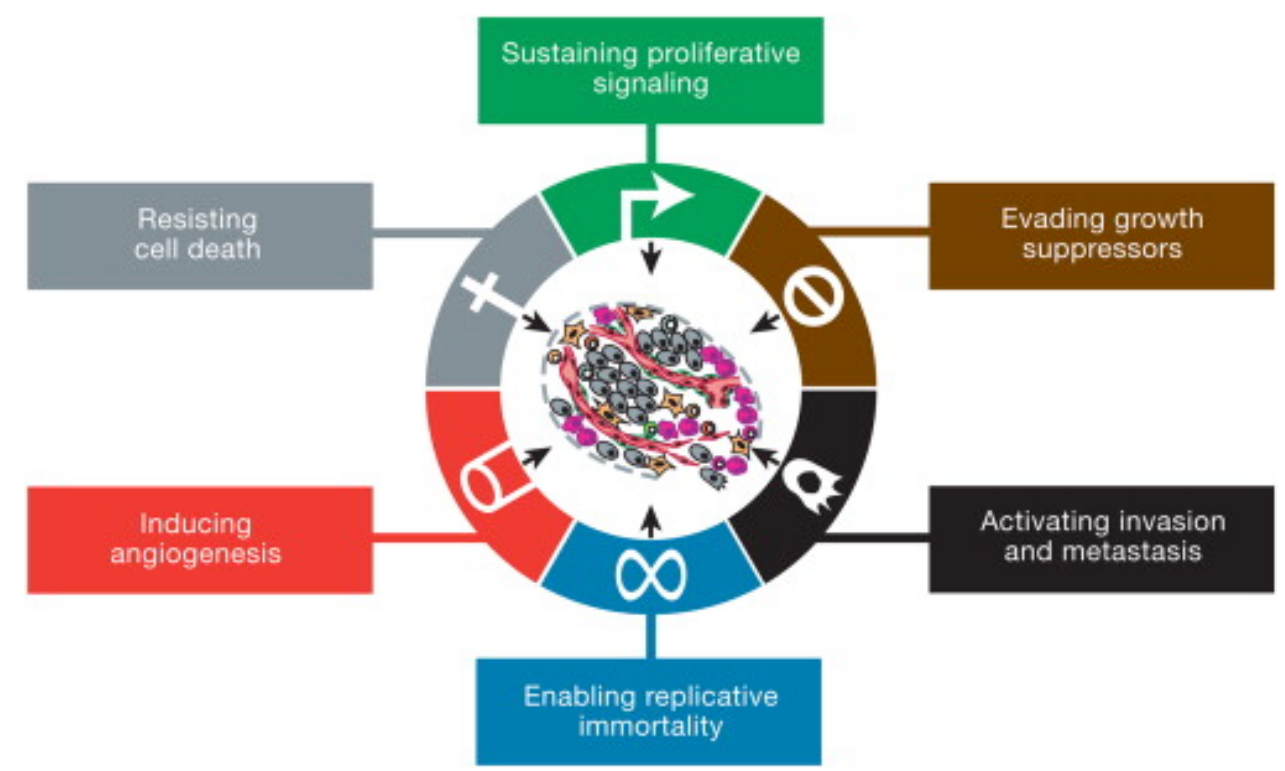

Figura 1. Processo de desenvolvimento das células cancerígenas. Adaptado de HANAHAN \& WEISBERG, 2011.

As células tumorais apresentam vias de sinalização intracelulares que 
respondem a sinais de proliferação descontrolada. Tais sinais podem ser desencadeados por estimulação de células a liberarem fatores de crescimento. Ademais, os tumores tornam-se insensíveis aos mecanismos de supressão do crescimento. Já o processo de angiogênese auto-sustentada ocorre quando os vasos sanguíneos são induzidos a proliferarem, pelo tumor, para manter o aporte de nutrientes e oxigênio. Após a angiogênese as células transitam pelos vasos e escapam para o parênquima favorecendo a invasão e metástase. 0 potencial de replicação ilimitado é estabilizada pelo aumento na expressão de telomerase, que mantém a replicação constante. A resistência a morte celular é caracterizado pela expressão de proteínas que inibem a apoptose (HANAHAN \& WINBERG 2011).

Devido a complexidade desses mecanismos fisiológicos e bioquímicos diversos estudos vem sido desenvolvidos para o tratamento do câncer. Algumas drogas antitumorais tem sido utilizada há mais de 30 anos para o tratamento de diferentes tipos de neoplasias humanas, tais como câncer de mama, ovário, próstata, endometrial, de cólon entre outros. Na Tabela 1 estão apresentados, de forma resumida, os agentes antineoplásicos mais usados no tratamento dos tipos de neoplasias citados (SILVERMAN, 1992; DE ALMEIDA, 2005).

Tabela 1. Dos principais agentes neoplásicos utilizados na clínica médica. ADAPTADO POR DE ALMEIDA, 2005.

\begin{tabular}{|ll|}
\hline Usos clínicos & Agente antineoplásico clinicamente usado \\
\hline $\begin{array}{l}\text { Carcinomas } \\
\text { de mama }\end{array}$ & $\begin{array}{l}\text { Melfalam, ciclofosfamida, mitomicina, daunorrubicina, } \\
\text { doxorrubicina, podofilo-toxinas (etoposida e teniposida), } \\
\text { vimblastina,vincristina, antiandrogênios, antiestrogênios, } \\
\text { estrogênios, metotrexato; taxol (casos avançados). }\end{array}$ \\
\hline de ovário & $\begin{array}{l}\text { Ifofosfamida, cisplatina, melfalam, cloram-bucil, } \\
\text { fluorouracil, doxorrubicina, vincristina, tamoxifeno. }\end{array}$ \\
\hline de próstata & $\begin{array}{l}\text { Fluorouracil, anti-androgênio, prednosona, doxorrubicina, } \\
\text { hidroxiuréia, progestinas, estrogênios, androgênios, } \\
\text { leuprolida, aminoglutetimida. }\end{array}$ \\
\hline endometrial & $\begin{array}{l}\text { Cisplatina, carboplatina, doxorrubicina, ciclofosfamida, } \\
\text { isofosfamida, progestina, estrogênios, anti-estrogênios. }\end{array}$ \\
\hline de cólon & Ciclofosfamida, fluorouracil. \\
\hline
\end{tabular}


Os tratamentos frequentemente utilizados na doença envolvem a combinação de cirurgia, radioterapia e quimioterapia, e podem causar, que além de vários efeitos colaterais, complicações decorrentes e até a morte do paciente (HYNES ET AL., 2004). Tais efeitos prejudiciais a saúde são caudados pela ação da droga que ocorre de forma não especifica, com citoxicidade intolerável, resistência as drogas devido ao ciclos repetidos de quimioterapia e baixos teores do medicamento no local do tumor (WANG, 2008; PATIL, 2010; MISRA, 2010).

O principal objetivo da quimioterapia é aniquilar as células cancerígenas e preservar as células saudáveis. No entanto, os agentes quimioterápicos, por não agirem de forma específica, lesam tanto células malignas quanto as normais, como por exemplo as gastrointestinais e as do sistema imunológico. Isto explica a maior parte dos efeitos colaterais da quimioterapia: náuseas, perda de cabelo e susceptibilidade maior às infecções (ALMEIDA, 2005). Morgan et al, revelaram que a adição da quimioterapia citotóxica à cirurgia ou radioterapia em 227.874 adultos com câncer aumentou a sobrevida de 5 anos em apenas 2,3\% (MORGAN et al, 2004).

Atualmente, há uma crescente tendência em investigar anticancerígenos derivados de bioativos naturais para sua utilização em combinação com os tratamentos convencionais a fim de aumentar a eficiência do tratamento diminuindo os efeitos colaterais (SRINIVAS, 2010; NAIR, 2010; ORLIKOVA, 2012; WANG, 2012).

Dentre os princípios ativos recentemente estudados com efeitos preventivos e antineoplásicos, o Indol-3-carbinol (I3C) (Figura 2) desponta como proeminente. Tal molécula vem sendo amplamente investigada pelas suas propriedades anticarcinogênicas para fígado, pulmão, cólon, endométrio, próstata e mama. O I3C é derivado da hidrólise do glicosinato em vegetais crucíferos, encontrado em grandes concentrações no brócolis, na couve e na couve de bruxelas apresenta propriedades anti cancerígenas, como a indução da apoptose, interrupção do ciclo celular, e a inibição da angiogénese, além de propriedades anti-inflamatórias (ACHARYA, 2010; QIAN, 2011; LUBET, 2011; WANG, 2012). 


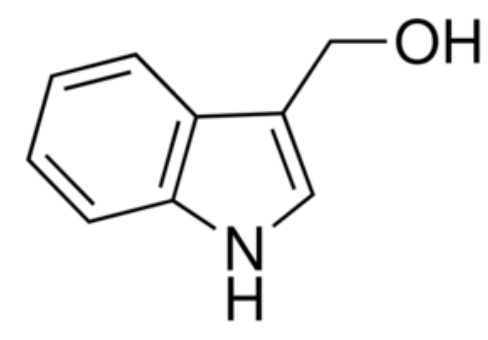

Figura 2. Estrutura molecular do indole-3-carbinol

Ademais, o $13 \mathrm{C}$ regula diversos eventos de sinalização relacionados com a proliferação de células cancerígenas, como por exemplo a expressão da transcrição da hTERT e CDK6, o que reduz significativamente a atividade da telomerase relacionado com o fim do ciclo celular de células cancerígenas (SUNDAR, 2006; MARCONETT, 2010; CRYSTAL, 2011). Além disso, o indol3-carbinol induz a degradação dos receptores de estrogênio (ERa), que diminui a transcrição do gene ERa e provoca o desequilíbrio de seus genes dependente, IGF1R e IRS1. Dessa forma, a inibição das sinalizações pelo I3C reduzem a proliferação de células do câncer de mama mediada por esses fatores (MARCONETT et al., 2012).

No entanto, a administração por via oral dos fitoquímicos pode tonar-se pouco biodisponível para os seres humanos devido ao metabolismo excessivo da fase 1 e fase 2 e a sua baixa solubilidade, o que pode dificultar sua absorção e distribuição pelo organismo (WANG, 2012). A quantidade de ácido indole-3-carbinol formado a partir do glicosinato em alimentos é variável e depende, em parte, no processamento e na preparação de alimentos. Os glicosinatos são compostos solúveis em água que podem ser lixiviados para a água no momento do cozimento. Algumas das técnicas dietéticas como a ebulição, vapor e microondas de alta potência (850-900 watts), podem inativar a mirosinase, a enzima que catalisa a hidrólise do glicosinato (WANG, 2012). Estudos em seres humanos têm mostrado que a inativação de mirosinase em vegetais crucíferos diminui substancialmente sua biodisponibilidade (SHAPIRO, 2001; ROUZAUD, 2004).

Devido a baixa biodisponibilidade desses bioativos e ausência de efeitos colaterais, estes se tornam interessantes para aplicação na área da nanotecnologia. Dos compostos já estudados e associados a nanotecnologia, encontram-se a curcumina, resveratrol, genisteína, daidzeína, 
epigalocatequina, quercitina, acido ursólico, acido elágico, acido caféico e eugenol (HAREESH, 2010). De acordo autores, o nanoencapsulamento da curcumina, aumentou em 9 vezes a sua biodisponibilidade oral em comparação com a administração oral de curcumina e piperina, um intensificador de absorção (SHAIKH, 2009).

Os sistemas terapêuticos com nanotecnologia são métodos de tratamento emergente para o câncer e outras doenças inflamatórias (HAREESH, 2010). Os perfis de biodistribuição e eficiência dos bioativos, dependem de características físico-químicas do bioconjugado (princípio ativo associado à nanoestrutura) como tamanho, solubilidade, carga de superfície e de outras propriedades biofísicas. O Instituto Nacional do Câncer reconhece que o uso da nanotecnologia aplicado à oncologia tem potencial para revolucionar a medicina moderna na detecção, tratamento e prevenção do câncer (INCA, 2012).

Estes sistemas, visam superar as barreiras e efeitos colaterais pelos anti-tumorais, dessa forma a nanotecnologia vem sendo utilizada na elaboração sistemas de carreamento de bioativos para alterar a farmacocinética e a biodistribuição, aumentar a especificidade para tecidos, órgãos ou células e melhorar o índice quimioterápico e a biodisponibilidade (RIEHEMANN, 2009; HUANG, 2010). Para aplicação na área da saúde, os mesoporosos são de grande interesse, pois agem como reservatórios para os princípios ativos, e promovem, por exemplo, a proteção dessas moléculas durante a absorção pelo organismo, o que evita sua degradação ou metabolização indesejada, além da manutenção da dose dentro de uma faixa terapêutica eficiente, com menos efeitos colaterais.

Estudos com silicatos de mesoporosos vem sendo conduzidos para maximar o efeito do tratamento do câncer. Os materiais poroso podem otimizar a absorção de partículas e diminuir a dosagem necessária do sistema de entrega de drogas. Essas estruturas podem ser alteradas quimicamente para melhorar a interação da droga com a sílica e assim, aumentar a especificidade da droga. Para isso, pesquisadores têm usado a funcionalização das sílicas com o ácido fólico (SLOWING, 2006; LIONG, 2008), a manose (BREVET, 2009), a transferrina (TF) e ácido aspartico Arginina-glicina (FERRIS, 2011), obtendo uma maior afinidade para as células cancerígenas. 
A expressão do receptor de folato por células cancerosas em sua superfície aumenta a absorção das nanopartículas ligadas ao folato, o que resulta em uma maior liberação terapêutica dos fármacos. O receptor de transferrina (TF) também é expresso por células cancerosas e a ligação de TF na superfície dos mesoporosos aumentam a condensação sobre as porções não-fosfotadas do ligante 3-glisil-oxipropil-trimetil-oxisilano. Este ligante reage com as aminas, o que permite o acoplamento da TF (LIONG, 2008). Ademais, as células cancerígenas têm uma alta taxa metabólica e está em constante demanda de nutrientes, o que aumenta a absorção de nanopartículas ligados a açúcares inerentes, como a ligação da manose, em sua superfície (BREVET, 2009; GARY, 2011).

Para examinar a capacidade dos mesoporosos de entregar drogas anticancerígenas, estes foram carregadas com doxorrubicina (DOX) e modificados com um anticorpo específico para o mesotelioma maligno (MMS). Os camundongos que receberam injeções com o mesoporoso ligado ao anticorpo e incorporado com DOX, tiveram uma redução significativa do volume e da proliferação de células tumorais comparado aos que receberam apenas DOX (SHERRILL, 2013).

\subsection{Mesoporosos}

Os mesoporosos são classificados de acordo com a porosidades em relação as suas dimensões do diâmetro do poro. Os materiais macro porosos possuem um diâmetro de poro excedendo $0,05 \mu \mathrm{m}$ ou $50 \mathrm{~nm}(500 \AA)$, materiais com diâmetro de poro que não excedem 2,0 nm (20 Å) são denominados microporosos e os mesoporosos são materiais com diâmetro de poro intermediário. Essa definição foi estabelecida pela IUPAC (International Union of Pure Applied Chemistry) (IUPAC, 1972).

As peneiras moleculares de óxido de silício mesoporosas descobertas por pesquisadores da Mobil Research and Development Corporation, em 1992, geraram uma série de materiais designados como grupo MCM, abreviatura de "Mobil Composition of Matter". Estes materiais foram sintetizadas com poros uniformes, com diâmetros que variam de $15 \AA$ para maiores do que $100 \AA$. Para 
a formação desses compostos utiliza-se um agente direcionador de estrutura (ADE), mecanismo chamado de cristal líquido moldante (liquid-crystal templating mechanism) (KRESGE, LEONOWICZ e ROTH, 1992.).

Os ADE's conduzem à formação do mesoporoso ordenado estruturalmente pela a condensação da sílica precursora sob condições básicas. O material é passado pelo processo de remoção do surfactante por extração e/ou calcinação. Na figura 3 encontram-se os mecanismos envolvidos na construção desses materiais (FROBA, HOFFMANN e CORNELIUS, 2006).

Na figura 3 ocorre a fase do cristal líquido poroso, pela organização das micelas do surfactante. Após a adição do silicato, este se organiza em torno do molde de cristal líquido. Após a formação do compósito constituído pela sílica e o surfactante, este é eliminado para obtenção de arranjo estrutural com os poros desobstruídos (FROBA, HOFFMANN e CORNELIUS, 2006).

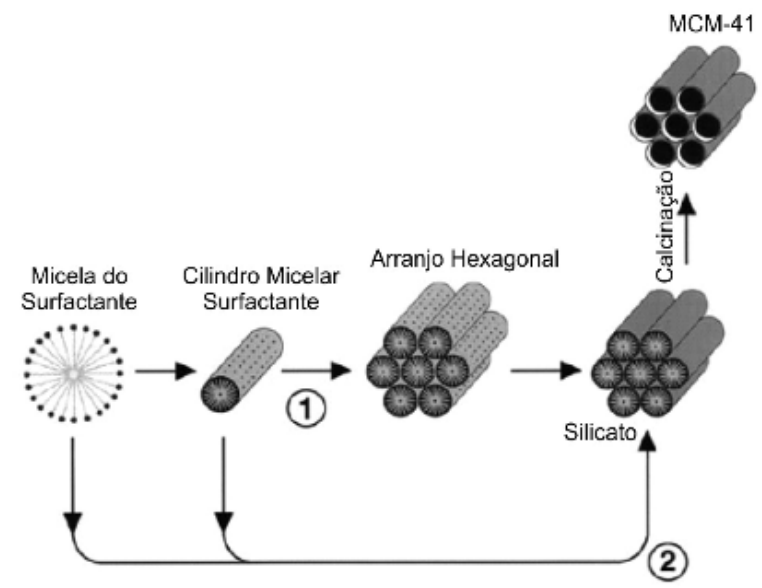

Figura 3. Mecanismo de formação de materiais mesoporosos por um surfactante: 1) fase cristal líquido inicial 2) Interação do silicato com o surfactante. Adaptado de FROBA, HOFFMANN e CORNELIUS, 2006.

A Figura 4 mostra alguns exemplos dos sólidos da família M41S que estão apresentados na fase hexagonal bidimensional (MCM-41), cúbica (MCM48) e lamelares (FROBA, HOFFMANN e CORNELIUS, 2006). 


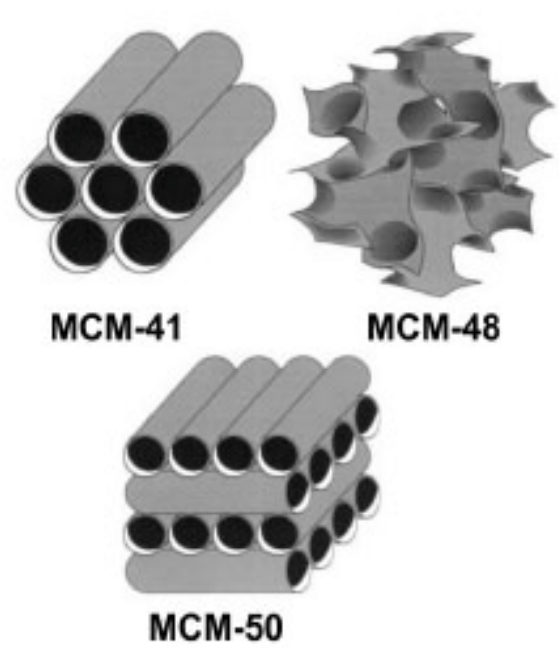

Figura 4. Mesoporosos do tipo M41S. Adaptado de FROBA, HOFFMANN e CORNELIUS, 2006.

\subsubsection{Mesoporoso do tipo SBA-16}

Os materiais mesoporosos são designados SBA-X (Santa Barbara amorfo), onde $X$ é um número que corresponde a uma estrutura de poros específico e surfactante. Esse tipo de material, em 1998, foi considerado um novo tipo de mesoporoso com poros maiores e com alto ordenamento estrutural. Como exemplo, o tipo hexagonal SBA-15 é com o surfactante pluronic F123 (P123), enquanto o SBA- 16 é formado em uma estrutura de corpo centrado cúbica pelo pluronic F127 (P127). Uma variedade de materiais SBA's estão descritos nos textos científicos, como exemplo SBA-1, SBA-11 e SBA-16 em formatos cúbicos, SBA-12 em 3D hexagonal, SBA-14 na estrutura lamelar e SBA-15 na forma 2D-hexagonal (ZHAO, HUO e FENG, 1998; VOORT, BENJELLOUN e VANSANT, 2002; KAO, WU e CHENG, 2006;MEYNEN, COOL e VANSANT, 2009).

Os mesoporosos estudados neste trabalho são classificados como materiais do tipo SBA-16, o qual está representado na Figura 5. Esta estrutura porosa é considerada de grande interesse devido ao seu arranjo centrado do grupo espacial Im3. O SBA-16 é sintetizado através de extensos blocos de óxido de polietileno (EO106-PO70-EO106), sob condições ácidas em temperatura ambiente. Além disso, a falta de interligação entre os canais permite poros individuais para servir como reservatórios independentes para a impregnação com fármacos e/ou fitoquímicos (SLOWING, 2008; GAO, 2009; 
MENG, 2010; HE, 2010; HE, 2011).

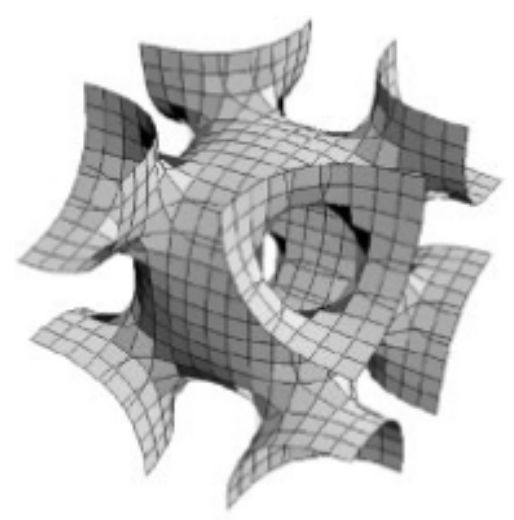

Figura 5. Mesoporoso cúbico do tipo SBA-16. ADAPTADO por SAKAMOTO, 2000.

\subsubsection{Métodos de Síntese (o processo sol-gel)}

O processo sol-gel é um dos principais processos utilizados para obtenção de materiais porosos. A parte do termo designado Sol é constituído de uma suspensão de partículas coloidais de dimensão entre 1 à 1000nm em um líquido. No entanto, a parte do termo gel é formado pela estrutura rígida de partículas coloidais ou por cadeias poliméricas que detêm água em seus interstícios (Figura 6) (HENCH, 1990; ATTARD, 1995, HIRATSUKA et al, 1995).

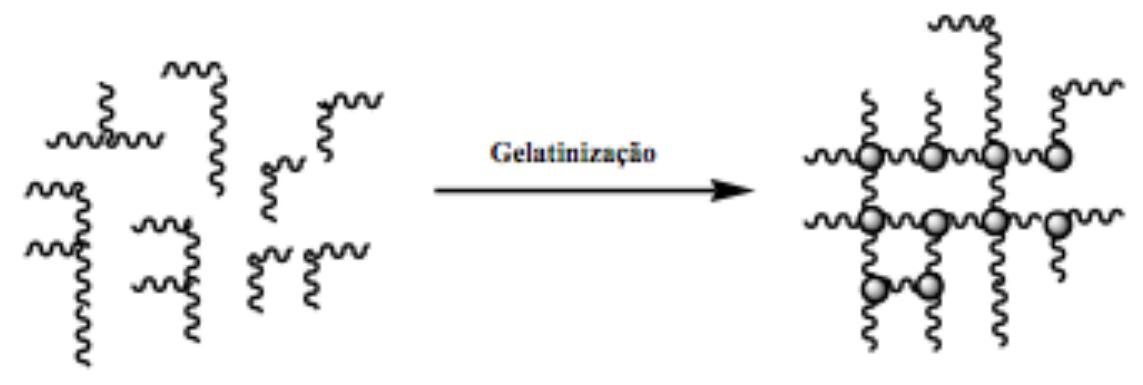

Figura 6. Esquema ilustrativo da gelatinização/reticulação do sistema polimérico. ADAPTADO POR BRINKER, 1990.

O processo sol-gel polimérico de alcoóxido de silício envolve reações químicas de hidrólise e condensação, descrito pelas equações 1, 2 e 3 abaixo: 
(a) Hidrólise do precursor:

$\mathrm{M}(\mathrm{OR})_{\mathrm{n}}+\mathrm{H}_{2} \mathrm{O} \rightarrow \mathrm{M}(\mathrm{OH})(\mathrm{OH})_{\mathrm{n}-1}+\mathrm{ROH}$

Onde $\mathrm{M}=\mathrm{Si}, \mathrm{Sn}, \mathrm{Ti}, \mathrm{Al}, \mathrm{Mo}$, ect.

(b) Simultaneamente à hidrólise, ocorre o processo de cor olação e oxolação, e polimerização:

Olação:

$$
\begin{aligned}
& \mathrm{M}-\mathrm{OH}+\mathrm{H}_{2} \mathrm{O}^{+}-\mathrm{M} \rightarrow \mathrm{M}-\mathrm{HO}^{+}-\mathrm{M}+\mathrm{H}_{2} \mathrm{O} \\
& \mathrm{M}-\mathrm{OH}+\mathrm{R}-\mathrm{HO}^{+}-\mathrm{M} \rightarrow \mathrm{M}-\mathrm{HO}^{+}-\mathrm{M}+\mathrm{ROH}
\end{aligned}
$$

Oxolação:

$$
\begin{aligned}
& \mathrm{M}-\mathrm{OH}+\mathrm{HO}-\mathrm{M} \rightarrow \mathrm{M}-\mathrm{O}-\mathrm{M}+\mathrm{H}_{2} \mathrm{O} \\
& \mathrm{M}-\mathrm{OH}+\mathrm{RO}-\mathrm{M} \rightarrow \mathrm{M}-\mathrm{O}-\mathrm{M}+\mathrm{ROH}
\end{aligned}
$$

A vias de condensação determinam a velocidade das reações, consequentemente a formação do gel. A via por olação corresponde a uma reação de substituição nuclofílica, onde o nucleófilo e o ligante de água é removido. Porém na via por oxolação a reação pode ocorrer correspondente a uma adição nucleofílica, onde os grupos ligantes não são removidos e dão origem as espécies condensadas de forma mais rápida (BRINKER et al, 1990).

Os parâmetros tais como temperatura, tempo, catalisador, e concentração de reagentes da reação influencia de forma decisiva na obtenção de um produto final com características físico-químicas estáveis, uma matriz monolítica com boa homogeneidade, dentre outras propriedades importantes na qualidade do produto final. Um catalisador básico dá origem em um produto final com cadeias poliméricas mais ramificadas por favorecer o processo de hidrólise. Enquanto um catalisador ácido dá origem a um produto com cadeias poliméricas mais longas, por favorecer o processo de condensação (BRINKER et al, 1990; JOSÉ et al, 2005). 


\subsubsection{Mecanismos de síntese do SBA-16}

Para obter-se um material do tipo SBA-16 é utilizado para a polimerização e formação do mesoporoso, o surfactante não-iônico P127. A automontagem do composto orgânico-inorgânico é impulsionado por ligações fracas não covalentes, como ligações de hidrogênio, forças de van der Waals, e ligações iônicas entre o surfactante e espécies inorgânicas. Na Figura 7 estão apresentados a formação do mesoporoso SBA-16 através da interação entre o surfactante orgânico, EO106PO70EO106, Pluronic F127, e os precursores inorgânicos representados pelos símbolos $+\mathrm{e} \cdot$, respectivamente. Em geral, as moléculas anfifílicas, contendo uma parte polar hidrofílica e uma parte não polar lipofílica, formam um cristal líquido por agregação em solução aquosa, vistos na Figura 7 em formato de x (KRESGE, 1992; ZHAO, 1998). Os parâmetros importantes para a formação da mesofase dependem principalmente das condições da solução, como por exemplo a temperatura, a concentração e o valor do pH da solução (HUO, 1994).

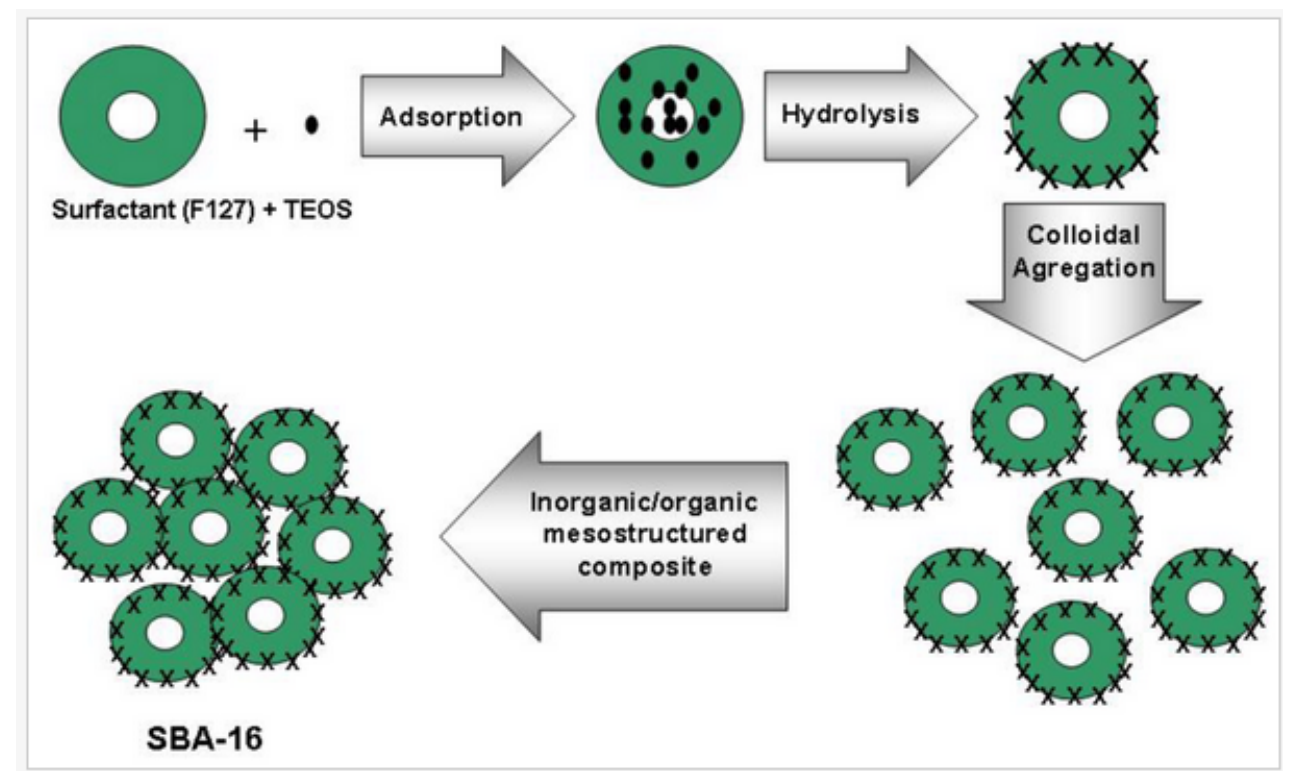

Figura 7. Representação do esquema do método da SBA-16. ADAPTADO POR MUÑOZ, 2010.

De acordo com alguns estudos, existem diferentes tentativas de desenvolver uma metodologia que pode influenciar nas interações na mesofase das reações de policondensação da fonte de sílica. Stucky et al. (2000), propuseram quatro vias sintéticas gerais, que são $S+I-, S-I+, S+X-I+$ e $S-X+I$, 
onde (S+) e (S-) são surfactantes catiônicos e aniônicos, (I+) e (I-), são precursores inorgânico catiônicos e aniônicos e $(\mathrm{X}+)$ e (X-), são contra-iãos catiônicos e aniônicos (MUÑOZ, 2010).

Por outro lado, a ligação de hidrogênio, mecanismos de interação, ou seja, SOI0 ou NOI0, foram propostos por Pinnavaia et al. (2011) para a preparação de silicatos mesoporosos sob condições neutras. Onde, S0 são aminas neutras, N0 são tensoativos não-iônicos e 10 são oligômeros hidratado de tretraortosilicato (TEOS). As vias de síntese utilizadas para SBA-16 são realizadas através dos copolímeros tribloco anfifílicos não-iônicos. Estas rotas são relativamente novas e têm mostrado uma alta flexibilidade na adaptação a condições de síntese e mesoestrutura do modelo cristal líquido.

\subsubsection{O agente direcionador de estrutura Pluronic F-127}

O pluronic F-127 (P127) é um surfactante não iônico composto de copolímeros polioxietileno-polioxipropileno em uma faixa de concentração de 20-30\%. São grãos brancos, moles, inodoros e insípidos, sendo que designação "F" refere-se a sua forma de floco. Em baixa concentração (10$15 \%$ ) ocorre formação de micelas isoladas, mas em alta concentração formamse micelas agregados constituídas por um centro hidrofóbico com cadeias hidrofílicas de polioxietileno na parte externa das micelas (Figura 8).

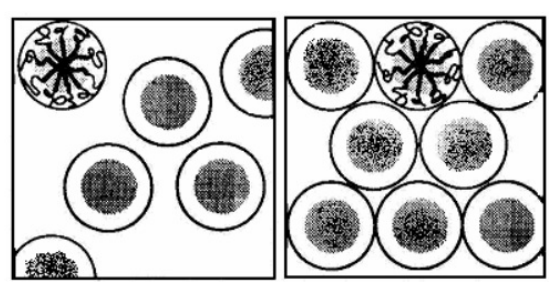

Figura 8. Formação de micelas isoladas e micelas agregadas. Adaptado de ESCOBARCHAVEZ e NAIK, 2006 apud LIMA, 2010.

O P127 em solução aquosa é estável em presença de ácidos, álcalis e íons metálicos. É comercialmente disponível como copolímero tri-bloco de polioxietileno- polioxipropileno de formula geral EO106PO70EO106 (Figura 9), com massa molar média de $13000 \mathrm{~g} / \mathrm{mol}$, contendo aproximadamente $70 \%$ de óxido de etileno, que é responsável pelo caráter hidrofílico (ESCOBARCHÁVEZ, LÓPEZ-CERVANTES e NAIK, 2006). 


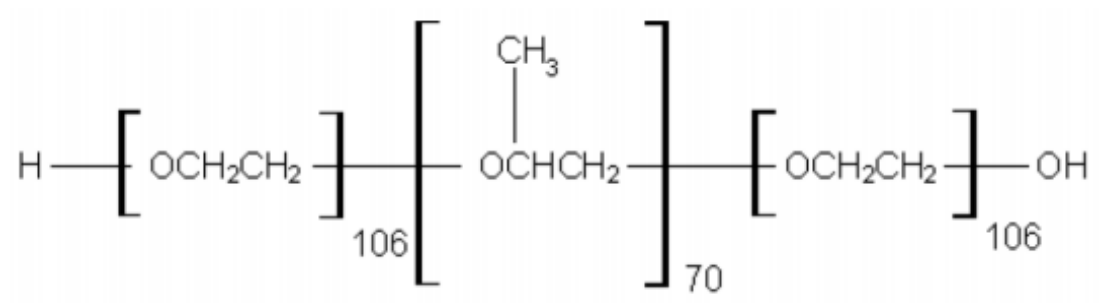

Figura 9. Estrutura química do Pluronic F127

Com o aumento da temperatura ocorre uma desidratação parcial das cadeias de óxido de etileno e uma redução do volume da coroa hidrofílica, consequentemente a repulsão entre elas. Por meio disso o raio do núcleo da micela aumenta como mostrado na Figura 10. Isso molda os grandes mesoporos em função do aumento da temperatura.

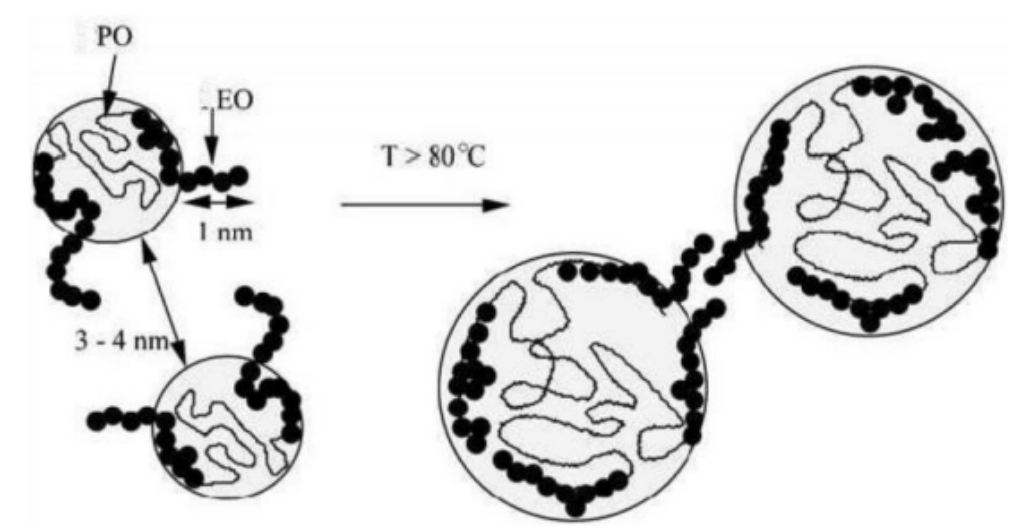

Figura 10. Representação esquemática da desidratação da micela com o aumento da temperatura. Adaptado de GALARNEAU, CAMBON e DI RENZO, 2003 apud LIMA, 2010.

\subsubsection{Sínteses de SBA-16}

O SBA-16 pode ser sintetizado sob condições ácidas e com diferentes teores de surfactante EO106PO70EO106 diluído (3-5\%), à temperatura controlada. Depois de reagir por 20 horas e envelhecido a uma temperatura de $80^{\circ} \mathrm{C}$ durante 2 dias, forma-se um SBA-16 de qualidade. Altas concentrações do copolímero resultam na formação do gel de sílica, enquanto baixas concentrações formam uma sílica amorfa (ZHAO, 1998). O primeiro relatório por Zhao et al. (1998) descreve uma preparação típica de 4,0g de Pluronic F127 dissolvidos em $30 \mathrm{~g}$ de água e $120 \mathrm{~g}$ de solução de $2 \mathrm{M}$ de $\mathrm{HCl}$, com agitação, à temperatura ambiente. Em seguida, $8,50 \mathrm{~g}$ de ortossilicato de tetraetilo (TEOS) são adicionados a esta solução, com agitação, durante 20h. A 
mistura é, em seguida, envelhecida a $80^{\circ} \mathrm{C}$ por $24 \mathrm{~h}$ sem agitação. O produto sólido é recuperado, lavado e seco ao ar, à temperatura ambiente. Os rendimentos são 98 \% (baseado em silício), o que está de acordo com a síntese descritas acima. A calcinação é realizada com aumento gradual da temperatura desde a temperatura ambiente até $500^{\circ} \mathrm{C}$ por 8 horas ou a $500^{\circ} \mathrm{C}$ durante 6 horas (ZHAO, 1998).

No entanto, Cheng et al. (2004) demonstraram que a SBA-16 pode ser preparada, mesmo após uma hora de agitação sob condições altamente ácidas. Li et al . (2006) mostraram que a mistura do copolímero Pluronic P127 e o surfactante sulfonato de sódio (SDS) proporcionou amostras de SBA-16 com mesoporos pequenos. Uma abordagem semelhante também foi usado por Mesa et al. (2005) que, em vez de misturar com SDS, usou brometo de cetiltrimetilamônio (CTMABr) como co-surfactante. Verificou-se que a presença de CTMABr catiónico pode regular a forma de micelas e a sua interação com os precursores da sílica na síntese SBA-16. Além disso, o CTABr ajuda a controlar a morfologia e regular a forma mesoestruturada de SBA-16 (MESA, 2005; CHEN, 2005; LIN, 2008). Já Kleitz et al. (2006) foram capazes de obter o SBA-16 sob uma variação das composições de TEOS e Pluronic P127, em um pH baixo, utilizando n-butanol como aditivo orgânico.

Dessa forma, a morfologia e o tamanho e distribuição dos poros da partícula são determinados principalmente pela regularidade e o grau de cobertura das micelas dos precursores de sílica, pelo grau de policondensação (acidez e temperatura), e pelos movimentos brownianos (temperatura) no momento da precipitação. A regularidade do arranjo estrutural $e$ as propriedades de porosidade do silicato de mesoporoso também estão relacionadas com os mesmos parâmetros (MESA, 2008).

\subsubsection{Remoção do surfactante}

A porosidade só pode ser obtida após a remoção do surfactante do composto inorgânico-orgânico sintetizado, assim como demonstrado na Figura 11. Diferentes métodos de remoção influenciam nas características do SBA-16. O método mais comum para remover o pluronic é a calcinação devido à facilidade de operação e completa eliminação. Os surfactantes orgânicos 
podem ser totalmente decompostos ou oxidado sob fluxo de oxigênio ou ar (WANG, 2007).

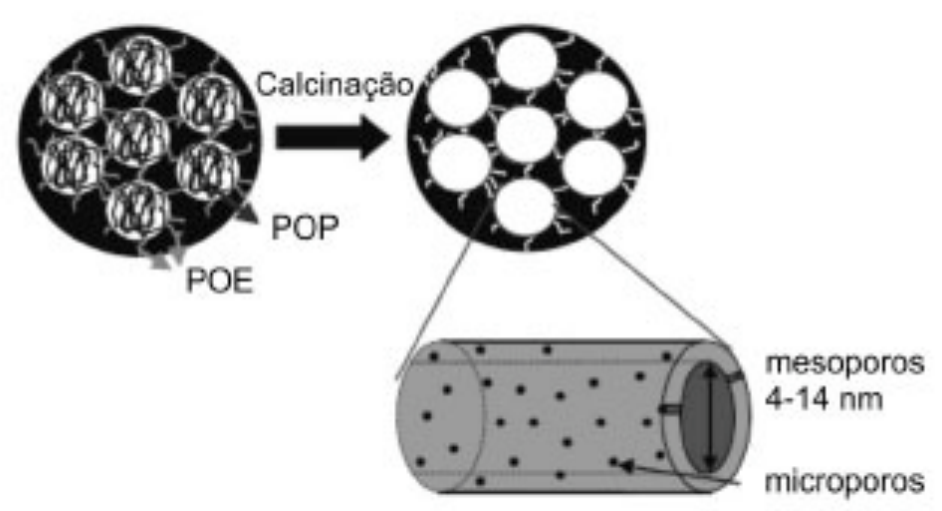

Figura 11. Ilustração da estrutura do mesoporoso SBA-15 após o tratamento térmico por calcinação. Adaptado de Greccol, 2013.

Para estudar o tratamento térmico eficiente duas etapas de calcinação foram adotadas por Mobil, sendo a primeira sob fluxo de nitrogênio por 1 hora para decompor o surfactante, e a segunda etapa sob fluxo de ar ou oxigênio por 5 horas (KRESGE, 1992). Este procedimento complicado foi simplificado, o primeiro passo de calcinação feito sob fluxo de nitrogênio pode ser substituído por uma baixa taxa de aquecimento, como exemplo uma taxa de $1-2^{\circ} \mathrm{C} / \mathrm{min}$ até $550^{\circ} \mathrm{C}$ e mantendo esta temperatura durante 4-6 horas. Dessa forma é possível remover completamente os modelos de copolímero de polioxietilenopolioxipropileno. Para que isso ocorra, as temperaturas de calcinação devem ser menores do que a temperatura de equilíbrio dos materiais, e maior do que $350^{\circ} \mathrm{C}$ para remover totalmente os tensioativos do tipo P127. Altas temperaturas de calcinação levam a menores áreas de superfície, volume dos poros e concentrações de grupos de hidroxila na superfície das sílicas.

A extração sob refluxo em meio etanol ácido é um método também adotado para remover surfactantes e obter porosidades nos materiais (ZHAO, 1998; KRUK, 2000). O etanol pode ser usado como um agente de extração orgânico. Uma pequena quantidade de ácido clorídrico é adicionada no agente de extração para melhorar a ligação cruzada de estruturas e para minimizar os efeitos sobre as mesoestruturas (WANG, 2007). Com o auxílio do ácido sulfúrico, os copolímeros também pode ser removido resultando em canais de poros e estruturas adequadas. (YANG, 2003; YANG, 2005; GRUDZIEN, 2006a) 
e com canais de poros e estruturas adequados. Além disso, novos procedimentos, incluindo o microondas (GALLIS, 2001; TIAN, 2002), fotocalcinação (HOZUMI, 2000) bem como extração com fluido super crítico (HUANG, 2005), também foram aplicados e demostraram ser benéficos para alguns mesoporosos.

\subsection{LIBERAÇÃO MODIFICADA}

A liberação modificada de bioativos visa manter a concentração do principio ativo liberado na faixa terapêutica para que a faixa tóxica e a subterapêutica não sejam alcançadas. Diferente dos princípios ativos convencionais, os sistemas de liberação modificada, permanece na circulação sanguínea o que torna a administração mais segura, eficiente e com uma toxicidade menor (DE AZEVEDO, 2002; MANADA, PINA, VEIGA, 2002). Tal tipo de liberação foi definido conceitualmente por Baker (1987), no qual ele caracteriza em um sistema que o principio ativo é liberado com cinética de razão exponencial equilibrada, capaz de prover algum controle terapêutico, seja da forma temporal, espacial ou ambos.

Dessa maneira, os estudos conduzidos para o desenvolvimento de novos sistemas de liberação sustentada tem como objetivo estudar a eficácia terapêutica e a menor toxicidade das drogas, assim como a distribuição do bioativo e o aumento da permanência de fármaco no organismo (CABRAL, 2004).

A tecnologia de liberação modificada oferecem inúmeras vantagens quando comparados a outros de dosagem convencionais, tais como: liberação progressiva e controlada com uma eficiência terapêutica maior, proteção dos fármacos em relação a instabilidade e degradação do principio ativo, maior especificidade da droga, doses menores devido ao controle da liberação e diminuição da toxicidade. Tal tecnologia envolve aspectos multidisciplinares diversos e pode contribuir para evolução dos tratamentos de doenças, e até a prevenção da saúde (ZHOA e CHONG, 2004).

$\mathrm{Na}$ Figura 12 ilustra o perfil de concentração plasmática da droga administrada oralmente em comparação com um sistema de liberação controlada. O primeiro exemplo mostrado na Figura 12 (a) é um fármaco que é 
liberado de forma sustentada. Na Figura 12 (b) pode-se observar um tipo de liberação convencional, onde após a administração da droga, ocorre um efeito máximo na corrente sanguínea seguido de uma queda após sua excreção ou metabolização. Essas oscilações dos níveis do principio ativo pode tornar a droga tóxica ou ineficiente em sua ação. Enquanto que a liberação controlada na Figura 12 (a) observa-se um nível desejado alcançado por um tempo prolongado sem chegar a níveis tóxicos no plasma (LANGER, 1990).

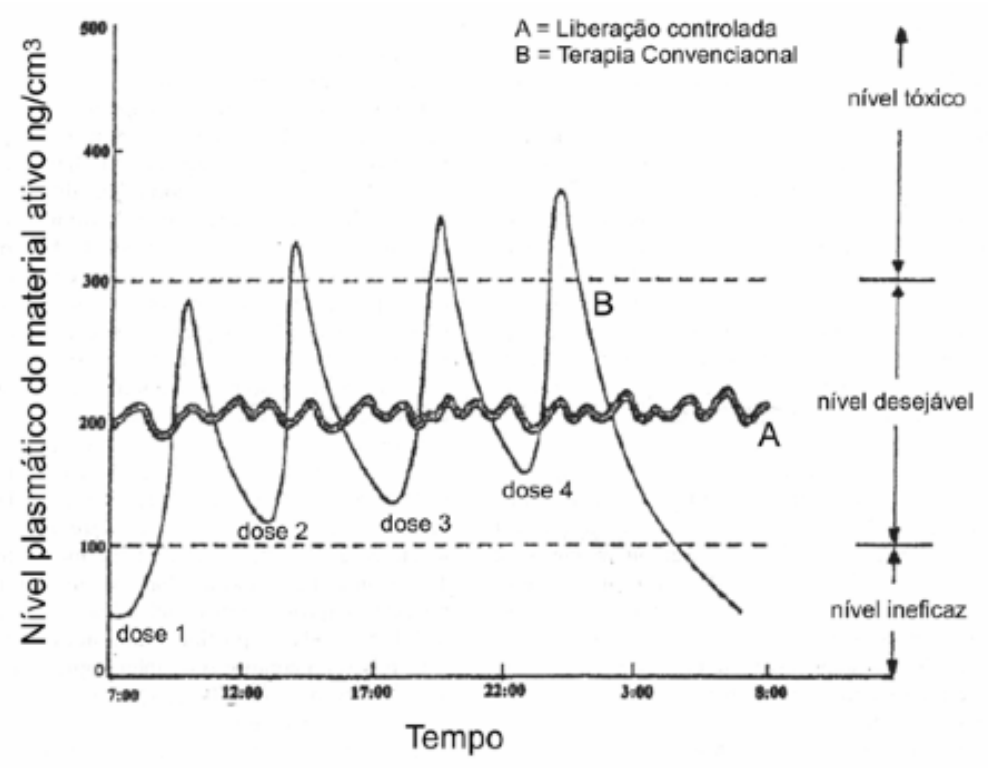

Figura 12. Níveis plasmáticos do principio ativo de um sistema convencional, comparado com um sistema de liberação sustentada. Adaptado de DASH \& CUDWORTH II, 1998.

Os estudos desses sistemas vem sendo desenvolvidos a partir de uma matriz inerte para terapias orais, transdérmicas e de implantes. Diversos materiais podem atuar como dispositivos de liberação tais como vidros, cerâmicas e polímeros. Para uma incorporação eficaz da droga no sistema é necessário que esses materiais sejam homogêneos quimicamente com uma estrutura porosa ordenada.

As famílias dos mesoporosos apresentam poros estreitos e homogêneos. Tais materiais são matrizes com enorme potencial para serem usados nesses tipos de sistemas, devido a sua estrutura ordenada, a sua elevada área superficial, tamanho e volume dos poros. Dessa forma, os materiais mesoporosos se apresentam como proeminentes na incorporação de 
ativos farmacêuticos, proteínas e outras moléculas biológicas. Alguns exemplos são a liberação de beta bloqueadores, antibióticos, hormônios entre outros (HATMANN, 2005).

Ainda na mesma direção, diversos tamanhos de moléculas podem ser adentrada nos mesoporosos por um método de incorporação e liberadas por um mecanismo de difusão controlado (HUMPHREY, 2005). Estes materiais absorvem facilmente as moléculas por um mecanismo simples de difusão que não altera a estrutura química dos poros do silicato, o qual também promove uma forma de controle da liberação (VALLET-REGÍ, 2007B). De acordo com Popovici et al. (2011), a liberação da droga a partir dos poros dos mesoporosos estão relacionadas em duas etapas: a primeira, o solvente difunde-se nos poros da sílica mesoporosa para dissolver o princípio ativo, e em seguida, as moléculas são dissolvidas e liberadas para fora dos poros.

Diversas pesquisas sobre os tipos de drogas e mesoporosos vem sendo estudadas para análise da incorporação e da liberação sustentada. Alguns pesquisadores estão utilizando as sílicas para armazenamento e liberação de princípios ativos por fotocontrole (FUJIWARA, 2003). Vallet-Regí et al (2004), incorporaram a gentamicina em mesoporosos do tipo SBA-15 e avaliaram as diferenças entre os materiais, em forma de pó e disco, do perfil de liberação pelo método de Cromatografia líquida de alta eficiência (HPLC). Os resultados desse estudo apresentaram taxas de liberação similares. Já Salonen, et al (2005), avaliaram a absorção e o comportamento de cinco tipos de drogas, quanto ao caráter ácido/base e lipofilicidade, na liberação prolongada a partir de uma matriz de sílica mesoporosa estável.

No entanto, o tamanho do fármaco e diâmetro dos poros são determinantes para a difusão da droga pela matriz mesoporosa (VALLETREGÍ, 2007b). Alguns fatores devem ser considerados para o uso de matrizes mesoporosas como meio de um sistema de liberação sustentada. Um fator relevante é a relação química entre o bioativo e os grupamentos silanóis da superfície da parede porosa. Modificações químicas dos grupos silanóis dos silicatos de mesoporosos podem melhorar a adsorção e o confinamento da droga nos poros e permitir uma liberação mais eficaz (VALLET- REGí, 2007b). Vallet et al. (2003) demonstraram que a SBA-15 um controle eficaz da taxa de liberação de antibióticos, alcançados após a funcionalização da superfície 
porosa com hidrocarbonetos de cadeia longa.

O outro fator importante para a incorporação da droga dentro da estrutura porosa das sílicas é as características da porosidade. Pois, a estrutura porosa servirá de abrigo para as moléculas adsorvidas, as quais devem estar compatíveis com a porosidade. De acordo com autores (VALLETREGÍ, 2003) o tamanho dos poros podem ser variados utilizando diferentes métodos de sínteses. Estes métodos, foram utilizados para investigação o perfil de liberação do ibuprofeno. Observou-se que a quantidade de ibuprofeno incorporada aumentou nos mesopososo com tamanho de poros maiores. Sugere-se que a variação do tamanho do poro afeta a incorporação de princípios ativos em sílicas mesoporosas (VALLET-REGí, 2003).

No entanto, Vallet et al. (2008), comparou a liberação sustentada de alendronato a partir mesoporosos do tipo MCM-41 (d=3nm) e SBA-15 (d=9 nm) com diferentes diâmetros de poros. Observou-se uma maior incorporação nos mesoporosos do tipo MCM-41 com tamanho de poros menores, um fato intrigante pois o diâmetro de poros SBA-15 possui um tamanho de poros maior do que o MCM-41. No entanto, o MCM-41 apresentou uma área de superfície $40 \%$ maior do que o tipo SBA-15, o que sugere um contato superficial da droga com o MCM-41 aumentado. Além disso, é possível que o alendronato tenham maiores interações químicas com a parede dos mesosporosos do tipo MCM41 (VALLET-REGÍ, 2008).

De acordo com o referencial teórico apresentado, este trabalho procurou-se obter diversas porosidades, usando teores diferentes das fontes de sílica, TEOS e silicato de sódio, com temperaturas dos tratamentos térmicos variadas, e assim, correlacionar com o perfil de liberação da molécula índole-3carbinol. 


\section{JUSTIFICATIVAS}

O tratamento oncológico pode levar a diversas complicações, inclusive a morte do paciente. Nos últimos anos, extensas pesquisas vem sendo realizadas com intuito de minimizar os riscos e contornar as barreira fisiológicas imposta pelas células cancerígenas. Os sistemas terapêuticos com nanotecnologia são métodos de tratamento emergente para o câncer e outras doenças inflamatórias (HAREESH, 2010). Para aplicação na área da saúde, os mesoporosos são de grande interesse, pois agem como reservatórios para os princípios ativos, e promovem, por exemplo, a proteção dessas moléculas durante a absorção pelo organismo, o que evita sua degradação ou metabolização indesejada, além da manutenção da dose dentro de uma faixa terapêutica eficiente, com menos efeitos colaterais (RIEHEMANN, 2009; HUANG, 2010).

Essas estruturas porosas podem ser alteradas quimicamente para melhorar a interação da droga com a sílica e assim, aumentar a especificidade da droga e formar um sistema de liberação modificado (SLOWING, 2006; LIONG, 2008). Além disso, os derivados de plantas ativos associados aos mesoporosos são promissores para minimizar as barreiras fisiológicas e efeitos colaterais do câncer, dentre eles encontra-se o indol-3-carbinol.

Considerando a inexistência de trabalhos com mesoporosos impregnados com indol-3-carbinol e a necessidade da evolução dos métodos do tratamento oncológico, o aumento da eficiência, diminuição dos efeitos colaterais dos tratamentos atualmente existentes, a proteção e a entrega de fitoquímicos para as células neoplásicas, este trabalho propõem o estudo da influência da morfologia de nanopartículas mesoporosas de silicatos na liberação do anticancerígeno indol-3-carbinol. 


\section{OBJETIVOS}

O objetivo principal deste trabalho visa o estudo de estruturas mesoporosas de óxido silicio para desenvolvimento de produtos capazes de controlar a liberação do anticancerígeno indol-3-carbinol. Com este trabalho pretende-se elucidar comportamentos dos produtos resultante destes compósitos nanoestruturados, buscando a caracterização e correlação entre a nanoestrutura do dispositivo final e a liberação do princípio ativo testado. Assim assume objetivos parciais tais como:

- Estudar as condições de síntese de pós mesoporosos visando obtenção de diferentes morfologias;

- Estudar as condições de impregnação;

- Estudar a liberação do ativo indol-3-carbinol em matrizes mesoporosas em etanol.

- Correlacionar as características estruturais, e morfológicas dos materiais mesoporosos obtidos com a capacidade de impregnação do principio ativo escolhido e o controle das taxas de liberação. 


\section{METODOLOGIA}

O desenvolvimento do presente trabalho envolveu inicialmente a síntese da sílica mesoporosa. Procurou-se variar as condições de síntese de modo a obter produtos com diferentes características porosimétricas típicas de um arranjo SBA-16. Foram avaliadas condições ótimas de remoção do surfactante bem como diferentes metodologias de impregnação do principio ativo I3C. Esse materiais foram caracterizados e analisados por uma série de técnicas que forneceram informações a respeito de suas texturas, estruturas e propriedades. E por fim, estudou-se as liberação dos I3C a partir de diferentes matrizes mesoporosas. A metodologia desenvolvida durante o estudo para se atingir os objetivos deste trabalho pode ser subdividida, sumariamente, nas etapas descritas a seguir.

\subsection{Reagentes}

Na Tabela 2 estão listados os reagentes e solventes que foram utilizados neste trabalho:

Tabela 2. Lista de reagentes e solventes

\begin{tabular}{|ll|}
\hline Reagentes & Marca \\
\hline Acetato de sódio & Vetec \\
\hline Ácido acético & Vetec \\
\hline Ácido clorídrico & Hcl 37\%, Sigma Aldrich \\
\hline Cloreto de sódio & Vetec \\
\hline Etanol 95\% & Vetec \\
\hline Pluronic 127 & BASF \\
\hline Água deionizada & \\
\hline TEOS & BASF \\
\hline Silicato de sódio & BASF \\
\hline Indole-3-carbinol & Sigma Aldrich \\
\hline
\end{tabular}




\subsection{Preparação das partículas mesoporosas}

Para a síntese dos mesoporosos de silicato foi adaptado um procedimento de autores (Liu et al, 2007), no qual 2,0 g de pluronic (P127) e $3,38 \mathrm{~g}$ de etanol foram dissolvidos em $56 \mathrm{ml}$ de solução tampão de ácido acético $\left(\mathrm{H}_{\mathrm{Ac}}\right)$ e acetato de sódio $\left(\mathrm{Na}_{\mathrm{Ac}}\right)\left(\mathrm{pH} 4,4, \mathrm{H}_{\mathrm{Ac}}: 0,52 \mathrm{~mol} / \mathrm{L}\right.$, de $\mathrm{Na}_{\mathrm{Ac}}: 0,27$ $\mathrm{mol} / \mathrm{L})$ à $25^{\circ} \mathrm{C}$, sob agitação vigorosa. O silicato de sódio (20\% de SiO 2,6\% de $\mathrm{Na}_{2} \mathrm{O}$ ) foi adicionado à solução anterior e agitado durante 10 minutos a $25^{\circ} \mathrm{C}$, em seguida o TEOS foi adicionado a solução. A mistura da reação foi agitada a $40^{\circ} \mathrm{C}$ durante 20 horas e envelhecida a $90^{\circ} \mathrm{C}$, em condições estáticas por mais 24 horas. $\mathrm{O}$ material obtido foi lavado com $\mathrm{H}_{2} \mathrm{O}$ e centrifugado, após a lavagem o surfactante foi extraído sob agitação por meio de uma solução composta de $200 \mathrm{ml}$ de etanol e $1,5 \mathrm{~g}$ de $\mathrm{HCl}(37 \%$ em peso) por $24 \mathrm{~h}$, e por calcinações à $550^{\circ} \mathrm{C}$ e $450^{\circ} \mathrm{C}$ por 4 horas e à $350^{\circ} \mathrm{C}$ por 10 horas. A razão molar dos géis obtidos foi de 100SiO2:1,02P127:85,2ácido acético:44,5 acetato sódio:215,7 etanol : $8921 \mathrm{H}_{2} \mathrm{O}$.

Diversas amostras foram preparadas variando os teores de silicato de sódio e TEOS. A nomenclatura das amostras obtidas neste trabalho foram denominadas referente ao percentual de TEOS $(T)$ e silicato de sódio, onde $T$ foi igual ao percentual de 0,12,50, 88 e 100, sendo que os valores de silicato foram variando da mesma maneira que o TEOS. Para melhor visualização do tipo de amostra apenas o T foi considerado. Na Tabela 3 encontram-se a nomenclatura das amostras que foram calcinadas à temperatura de $350^{\circ} \mathrm{C} \mathrm{e}$ um tempo de10 horas definidos no estudo da remoção do surfactante item 3.4.

Tabela 3. Nomenclatura dos mesoporosos estudados.

\begin{tabular}{|lll|}
\hline AMOSTRAS & \%TEOS & \%Si \\
\hline T0 & $0 \%$ & $100 \%$ \\
\hline T12 & $12 \%$ & $88 \%$ \\
\hline T50 & $50 \%$ & $50 \%$ \\
\hline T88 & $88 \%$ & $12 \%$ \\
\hline T100 & $100 \%$ & $0 \%$ \\
\hline
\end{tabular}

T- TEOS 


\subsection{Estudo da remoção do surfactante}

Para verificar a forma mais eficiente da retirada do surfactante foi feito uma revisão bibliográfica. A metodologia empregada foi a revisão sistemática, que se baseia em estudos primários, utilizando métodos previamente definidos e explícitos para identificar, selecionar e avaliar criticamente pesquisas consideradas relevantes (MULROW, 1994).

A Identificação dos artigos foi feita através da busca bibliográfica nos bancos de dados informatizados Pubmed de 1998 a 2015.

As palavras-chaves utilizadas na identificação dos artigos foram: "Mesoporous materials; mesoporous silica; SBA-16-type mesoporous silica; Morphology; Porosity; Surfactant degradation. Os critérios de inclusão para a seleção dos artigos foram: artigos originais de pesquisa sobre a síntese dos mesoporosos, assim como a temperatura e tempo de calcinação utilizados, publicados em inglês e português e estudos apresentados em dissertações e teses. Os critérios de exclusão foram: artigos que não obtiveram uma metodologia clara em relação a temperatura e tempo de calcinação.

A Tabela referente a revisão bibliográfica se encontra no Anexo 1. Após a revisão, os mesoporosos foram calcinados em diversas temperaturas de acordo com a Tabela 4, afim de se obter uma estrutura livre do surfactante e verificar possíveis alterações na estrutura porosa. Todos os materiais foram calcinados em mufla sem o uso de fluxo de ar.

Tabela 4- Temperatura e tempo de calcinação utilizado nos tratamento térmico.

\begin{tabular}{|ll|}
\hline Temperatura & Tempo \\
\hline $\mathbf{3 5 0 ^ { \circ } \mathrm { C }}$ & 10 horas \\
\hline $\mathbf{4 5 0 ^ { \circ } \mathrm { C }}$ & 4 horas \\
\hline $\mathbf{5 5 0 ^ { \circ } \mathrm { C }}$ & 4 horas \\
\hline $\mathbf{8 0 0 ^ { \circ } \mathrm { C }}$ & 2 horas \\
\hline
\end{tabular}

A síntese das partículas mesoporosas e os tratamentos térmicos utilizados para a remoção do surfactante estão apresentados no orgonograma da Figura 13. 


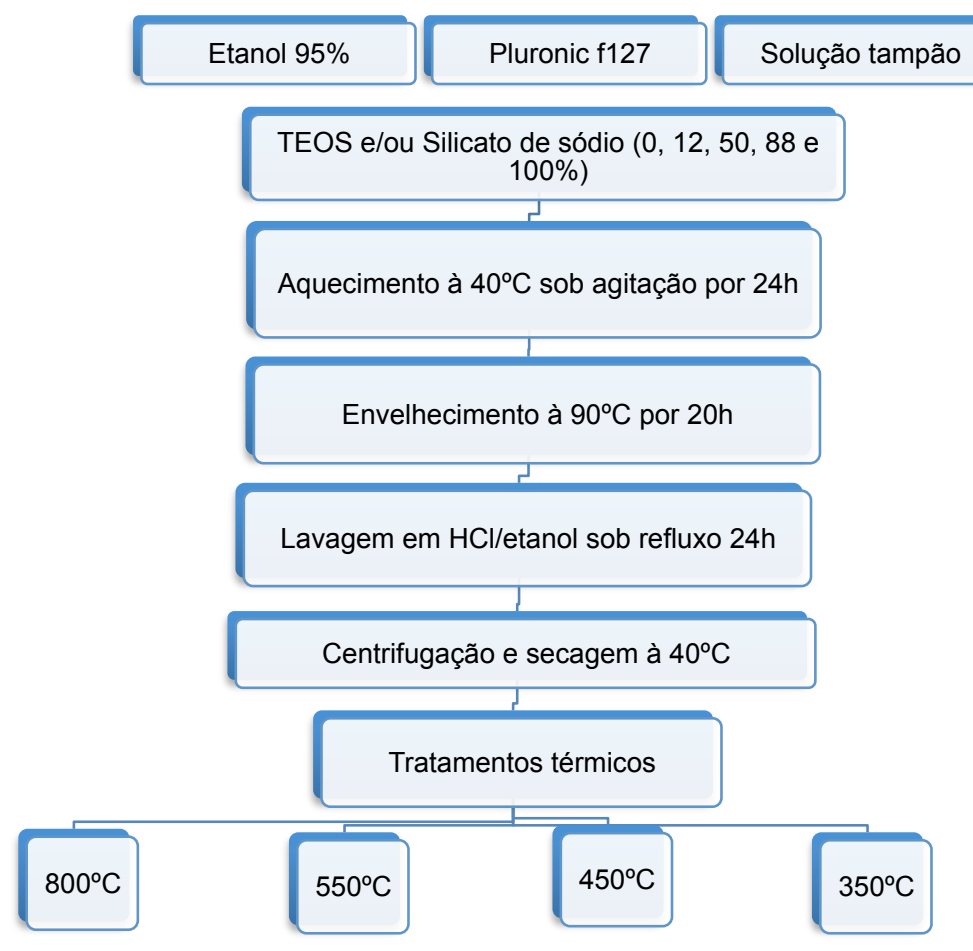

Figura 13. Orgonograma da metodologia de síntese e tratamento do térmico dos materiais mesoporosos

\subsection{Impregnação das partículas mesoporosas com Indol-3-carbinol}

Para a impregnação das partículas mesoporosas, ensaios de incorporação foram realizados, usou-se $10 \mathrm{mg}$ de indol para cada amostra sintetizada e calcinada à $350^{\circ} \mathrm{C}$ por 10 horas. Na Tabela 5 encontram-se $\mathrm{o}$ tempo de agitação mecânica dos mesoporosos, com 0\%, 50\%, 88\% e 100\% de TEOS, incorporados com I3C.

Tabela 5. Óxidos de silícios de mesoporosos calcinadas à $350^{\circ} \mathrm{C}$ por 10 horas e impregnadas sob agitação mecânica por 45 horas.

\begin{tabular}{|cc|}
\hline Amostra & Tempo de agitação \\
\hline T0 & 45 horas \\
\hline T12 & 45 horas \\
\hline T50 & 45 horas \\
\hline T88 & 45 horas \\
\hline T100 & 45 horas \\
\hline
\end{tabular}

O Indol-3-carbinol (I3C) foi misturado com os materiais obtidos, por ultrassom durante 5 minutos e agitação magnética por 45 horas. As amostras 
foram pesadas, em $50 \mathrm{mg}$, as quais foram colocadas em contato com $2,5 \mathrm{ml}$ de uma solução indol-3-carbinol/etanol em uma concentração de $4 \mathrm{mg} / \mathrm{ml}$. Após o término da agitação as soluções foram lavadas com $25 \mathrm{ml}$ de etanol para retirada do excesso do $13 \mathrm{C}$ da superfície dos mesoporosos. As amostras foram separadas por centrifugação e seca em temperatura ambiente por $24 \mathrm{~h}$. O sobrenadante foi coletado e analisado por espectroscopia no ultravioleta visível (UV/Vis), com objetivo de verificar o quanto sobrou do I3C não impregnado. Para isso foi necessário obter uma curva de calibração referente a absorbância do I3C no UV/Vis. Os valores da curva de calibração foram encontrados a partir da diluição de uma solução indol-3-carbinol/etanol em uma concentração de $2 \mathrm{mg} / \mathrm{L}$, os resultados da curva estão descritos nos resultados e discussão.

Após as medições da curva de calibração foi possível obter por UV/Vis a absorbância referente a concentração do indol-3-carbinol. Dessa forma, o sobrenadante foi quantificado e analisado. A equação (4) utilizada para estimar a quantidade de I3C, a partir do resultados da coleta do sobrenadante, foi a da diluição:

$$
\text { Mi.Vi=Mf.Vf }
$$

onde Mi é a massa inicial , Vi o volume inicial, Mf a massa final e Vf o volume final.

O método de impregnação encontra-se resumido no organograma da Figura 14 abaixo:

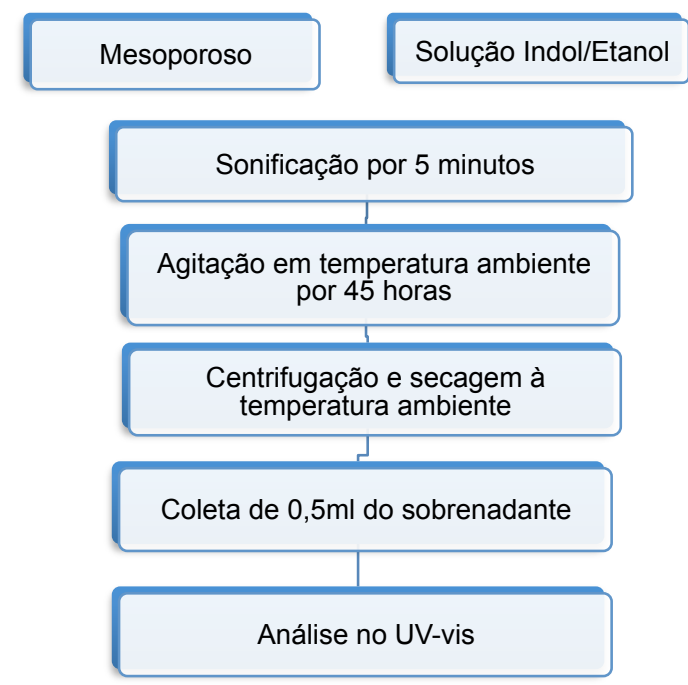

Figura 14. Orgonograma da metodologia de impregnação dos materiais mesoporosos com indol-3-carbinol 


\subsection{Caracterização das amostras}

Varias técnicas de caracterizações foram empregadas para analisar os materiais mesoporosos sintetizados, impregnados e aplicados nos ensaios de liberação. Esses materiais foram examinados com relação à organização das estruturas, volume dos poros, área superficial, os tipos de grupos funcionais na superfície, bem como a quantidade dos mesmos. Para tanto, foram usadas as seguintes técnicas: espectroscopias de absorção na região do infravermelho, calorimetria exploratória diferencial, difração de raios $X$, adsorção/dessorção de nitrogênio, ressonância paramagnética eletrônica, potencial zeta, espectroscopia no ultravioleta visível (UV/Vis), microscopias eletrônicas de varredura e transmissão.

\subsubsection{Espectroscopia de Absorção na Região do Infravermelho por transformada de FOURIER (FTIR)}

As amostras foram analisadas por espectroscopia de absorção na região espectral 400 à $4500 \mathrm{~cm}^{-1}$, pelo equipamento de espectrofotômetro de infravermelho por transformada de Fourier FT, marca SHIMADZU, modelo IRPRESTIGE-21. Tal análise visou identificar qualitativamente as bandas de absorção referentes aos grupos inorgânicos e orgânicos presentes referentes a cadeia estrutural do mesoporoso puro e impregnado. Os espectros foram obtidos a partir de pastilhas feitas com 100mg de um agente dispersante, o Brometo de sódio ( $\mathrm{KBr}$ ), e amostras com $2 \%$ em peso da quantidade do $\mathrm{KBr}$. A pastilha com a composição citada acima foi obtida por meio de uma Prensa Carver hidráulica.

\subsubsection{Análises térmicas}

As amostras foram estudadas por calorimetria exploratória diferencial (DSC). A análise por DSC foi empregada com o intuito de verificar a quantidade de energia envolvida nos eventos térmicos durante um programa controlado de temperatura a qual as amostras foram submetidas, bem como, identificar as ocorrências de natureza endotérmicas ou exotérmicas envolvidas na presença do P127 nas amostras estudadas. Para isto, foi utilizado o equipamento de 
DSC-60 da marca Shimadzu. Nas análises, foram pesadas cerca de 3,5mg de material em panela de alumínio a qual foi tampada. Uma panela vazia foi utilizada como referência. A amostra foi aquecida até uma temperatura de $350^{\circ} \mathrm{C}$, sob uma razão de aquecimento de $20^{\circ} \mathrm{C} \cdot \mathrm{min}^{-1}$, sob atmosfera inerte de nitrogênio a $20 \mathrm{~mL} \cdot \mathrm{min}^{-1}$.

\subsubsection{Difração a raios $X$}

A estrutura cristalográfica das sílicas mesoporosas foi caracterizada pela técnica de difração de raios X. O equipamento utilizado foi o Rigaku $D / m a x-R B$ difratrômetro com Cu Ka radiação $(\lambda=1,5418 \hat{A})$, em varredura $2 \theta$ igual $10^{\circ}$ a $80^{\circ} \mathrm{em}$ passos de $0,02^{\circ}$ minuto. $O$ objetivo dessa técnica visou identificar a cristalinidade das amostras após calcinação por diferentes temperaturas dos tratamentos térmicos dos mesoporosos obtidos.

Além disso, obteve-se o arranjo simétrico das matrizes mesoporosas por difração de raios $X$ a ângulos rasantes. As medidas foram feitas no equipamento, D8 Discover difratrômetro com Cu Ka radiação $(\lambda=1,5418$ Â), e realizadas no departamento de física Universidade Federal de Viçosa. Considerando os valores de espaçamento interplanar dos planos cristalográficos do índice miller (hkl) para materiais mesoporosos a incidência dos ângulos rasantes foram de $2 \theta$ igual a 0,2 -4.

Os valores de espaçamento interplanar (d) podem ser obtidos a partir da equação (5) de Bragg:

$$
d=\lambda / \operatorname{sen} 2 \theta
$$

Onde $\theta$ é $o$ ângulo de incidência; $d$ é a distância interplanar e $\lambda$ é $o$ comprimento de onda incidente.

Usando valores da distância interplanar é possível obter o parâmetro de célula unitária $a^{0}$ que no caso da mesoestrutura cúbica é calculado por (Equação 6)

$$
a^{0}=d(110) \times \sqrt{2}
$$


O cálculo de espessura da parede de poros das amostras, pode ser obtido através da equação 7:

$$
a^{0}=D_{p}+h
$$

onde $D_{p}$ é o diâmetro de poros e h a espessura da parede dos poros.

\subsubsection{Adsorção e Dessorção de Nitrogênio}

Os parâmetros texturais como área específica, diâmetro médio de poro e volume de poro foram obtidos através de experimentos da adsorção e dessorção de nitrogênio à $-196,14{ }^{\circ} \mathrm{C}$, em um equipamento ASAP 2020C (Accelerated Surface Area and Porosimetry System) fabricado pela Micromeritics.

Os resultados foram obtidos no Instituto de Química da Universidade de Brasília-UNB. Antes de serem analisadas, 0,3g das amostras foram secas por 12 horas a $300^{\circ} \mathrm{C}$ sob vácuo. O cálculo da área específica (composição da área de microporos com a área externa) foi realizado a partir da isotermas de adsorção de nitrogênio utilizando-se o método de Brunauer-Emmett-Teller (BET) na faixa de pressão relativa de P/P0 de 0,01 a 0,20. A isoterma de dessorção de nitrogênio e aplicou-se o método de Barrett-Joyner-Halenda (BJH) para determinar a área do mesoporosos.

As isotermas de adsorção de nitrogênio são classificadas em 6 tipos, de I a $\mathrm{VI}$, dos quais foram propostas por Brunauer, Emmett e Teller e Pierce (GREGG, 1982 apud BALZER, 2014). A Figura 15 apresenta as seis clasess de classificação das isotermas. 


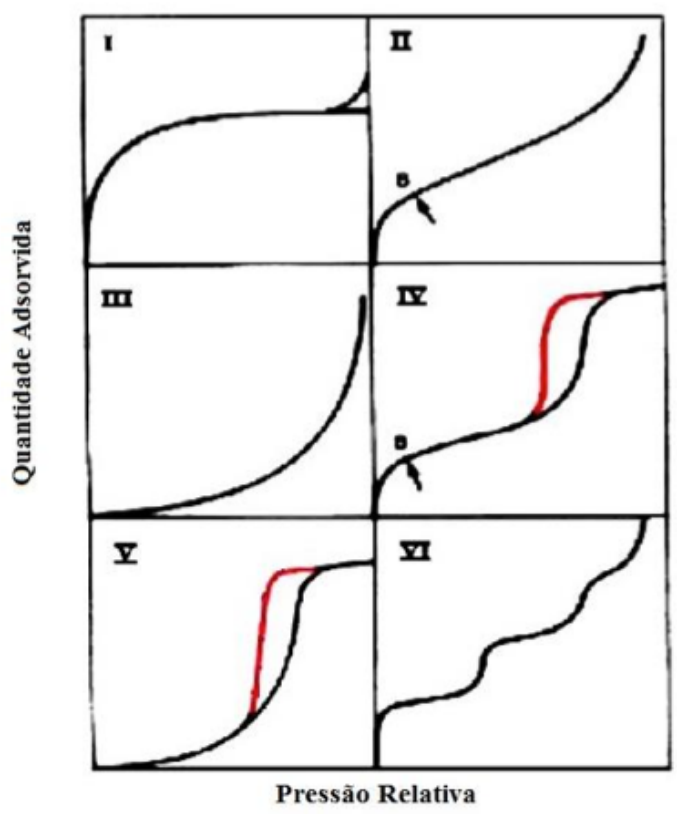

Figura 15. Classificação das isotermas de adsorção e dessorção de nitrogênio.

As isotérmicas do tipo I é definido a partir de pressões baixas e correspondem ao um mecanismo de adsorção em microporos e são característicos de sólidos microporosos e com áreas desprezíveis. O volume de microporos pode ser relacionado com a altura do patamar, pois esse está interligado com o preenchimento completo dos microporos (BALZER, 2014).

As isotermas II e III são características da adsorção em multicamadas, essa observação pode ocorrer em sólidos não porosos, sólidos macro porosos ou materiais com mesoporos.

As isotermas IV e $\mathrm{V}$ apresentam patamares bem definidos indicam a condensação capilar, esse patamar corresponde ao enchimento de todos os poros com o adsorvido no estado liquido.

$\mathrm{E}$ a isoterma $\mathrm{VI}$ ocorre em superfícies uniformes não porosas, indicando uma adsorção camada a camada. E a altura do degrau corresponde à capacidade da monocamada em cada camada adsorvida (BALZER, 2014).

Ademais, as isotermas do tipo IV e V são características de possuírem histereses. Isso ocorre quando as isotermas de adsorção e dessorção não coincidem, devido a pressões de saturação não serem iguais para a condensação e para a evaporação no interior dos poros. A Figura 16 apresenta os 4 tipos de histereses (BALZER, 2014). 


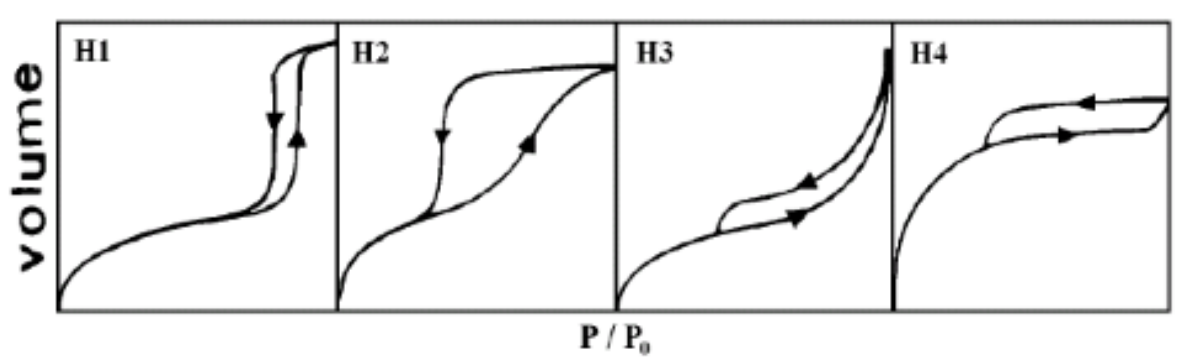

Figura 16. Tipos de histerese. Adaptado por BLAZER, 2014.

Histerese tipo H1: É caracterizada por dois ramos da isoterma, quase paralelos. Geralmente é associada a materiais porosos constituídos por aglomerados rígidos de partículas esféricas de tamanho uniforme.

Histerese tipo H2: Ocorre quando somente o ramo de dessorção é praticamente vertical. Associa em poros com gargalo estreito e corpo largo.

Histerese tipo H3: Caracterizada por dois ramos assintóticos relativamente vertical $P / P_{0}=1$. É associada a agregados não rígidos de partículas em forma de placa, originando poros em fenda.

Histerese tipo H4: É representada por dois ramos praticamente horizontais e paralelos.

\subsubsection{Microscopia Eletrônica de Varredura (MEV)}

As micrografias por microscopia eletrônica de varredura visou avaliar morfologicamente as amostras sintetizadas com diferentes teores de TEOS e silicato de sódio. As amostras foram depositadas sobre uma fita adesiva de carbono fixado no porta-amostra e depois metalizada com platina. As imagens obtidas e ampliadas na escala de 200, 1000 e 5000nm, foram medidas pelo microscópio da marca Quanta FEG 250, no laboratório de microscopia da Faculdade de Celiândia da Universidade de Brasília.

\subsubsection{Microscopia eletrônica de transmissão (MET)}

A microscopia eletrônica das amostras obtidas com diversos teores de TEOS ( $0 \%$ à $100 \%$ ), utilizou-se o microscópio eletrônico de transmissão da marca JEOL JEM-2100, instalado no Laboratório Multiusuário de Microscopia de Alta Resolução (LabMic) da Universidade Federal de Goiás (UFG), operando a $200 \mathrm{kV}$. Para a medida, o pó da amostra foi disperso sobre uma 
grade de cobre coberta com membrana de carbono.

\subsubsection{Potencial zeta das partículas.}

Para a análise através do equipamento Malvern Zeta Sizer Nano, realizadas no Laboratório de Nanobiotecnologia do CEM 4 na Universidade de Brasília. As amostras com 0\%,12\%, 50\%, 88\% e 100\% de TEOS foram diluídas em água deionizada numa concentração de $0,001 \mathrm{mg} / \mathrm{ml}$. Analisou-se as soluções coletadas com uma seringa e transferida para cubeta, a cada medida, o $\mathrm{pH}$ do meio foi alterado a fim de verificar a correlação do meio ácido/base com a carga e tamanho hidrodinâmico dos mesoporosos estudados.

\subsubsection{Espectroscopia de ressonância paramagnética eletrônica (EPR)}

Os espectros de EPR foram obtidos com objetivo de analisar campo de elétrons promovido pelos poros gerando pontes de defeito, das amostras puras e impregnadas. Os dados foram coletados no Laboratório de Física da Universidade Brasília, no espectrofotômetro de ressonância paramagnética eletrônica, modelo Bruker EMX PremiumX equipado com o ressoador ER 4102ST. As condições operacionais foram estabelecidas na banda $X$ (frequência de $9,5 \mathrm{GHz}$ ) com um potência de microondas de $50 \mathrm{~mW}$, no intervalo de campomagnético de 0 a 5 Gauss, em temperatura ambiente.

\subsubsection{Espectroscopia no ultravioleta visível (UV/Vis)}

Os ensaios de liberação foram realizados utilizando um espectrofotômetro da marca Hitachi, modelo U-3900H spectrophotometer. A amostra foi pesado em $3,5 \mathrm{mg}$ e imersos dentro de uma cubeta de quartzo de $10 \mathrm{~mm}$, foi colocado 3 mililitros de etanol 95\% e medida na região de absorbância de 200 à $321 \mathrm{~nm}$ em um ciclo de intervalos de 15 em 15 minutos por 25 horas sob temperatura controlada de $25^{\circ} \mathrm{C}$. A quantidade de indol-3-cabrinol também foram medidas pelo UV-vis nas mesmas condições já descritas. Após a lavagem e secagem dos compostos impregnados foram coletados $0,5 \mathrm{ml}$ do sobrenadante $\mathrm{e}$ misturado com 2,5 ml de etanol. A concentração do sobrenadante foi estimada pela equação (4), a partir da curva de calibração apresentada nos resultados e discussões item 4.4 . 


\section{Apresentação do resultados e discussões segue a seguinte forma:}

Inicialmente são mostrados estudos sobre remoção do surfactante com o objetivo de determinar o tempo e temperatura ideal para remoção completa do surfactante. Na sequência são apresentados resultados sobre a caracterização da estrutura porosa formada mostrando sua morfologia e carga de superfície, correlacionando o método de síntese, calcinação e a variação das estruturas empregados nos silicatos de mesoporoso com a estrutura porosa obtida. Por fim, são mostrados os ensaios de liberação do ativo indol-3-carbinol de diferentes amostras. Serão apresentadas uma correlação das características da matriz mesoporosa com a liberação do ativo.

\subsection{Estudo da remoção do surfactante}

Afim de se avaliar os diferentes processos de remoção do surfactante adotado, foram realizadas medidas de espectroscopia no infravermelho de amostras de SBA-16 tratadas sob diferentes métodos de eliminação do surfactante.

A Figura 17, apresenta o espectro do infravermelho registrados em $400 \mathrm{~cm}-1$ a $4500 \mathrm{~cm}^{-1}$ do P127. Podemos observar na Figura bandas de absorção centradas em $3500 \mathrm{~cm}^{-1}$ e $2900 \mathrm{~cm}^{-1}$, relativas ao estiramento simétrico de O-H (álcool) e C-H (carbono $\mathrm{sp}^{2}$ ) (WU et al., 2012), respectivamente. A banda de absorção referente a deformação da ligação $\mathrm{C}-\mathrm{H}$ de grupos $\mathrm{CH}_{2}$ encontra-se centrada em $1460 \mathrm{~cm}^{-1}$. $\mathrm{E}$ ainda, observa-se também na Figura $17 \mathrm{com}$ a banda de absorção em torno de $1103 \mathrm{~cm}^{-1}$ relativa as deformação da ligação de grupos C-O (éter). Na Figura 17 (b) e (c) estão representados a estrutura química do $\mathrm{P} 127$ e os grupamentos funcionais, respectivamente.

Essas vibrações intensas foram usadas como referência na analise qualitativa da presença do composto $\mathrm{P} 127$ nos materiais mesoporosos obtidos. Foram estudados dois métodos de remoção do surfactante, a saber extração com etanol/HCl sob refluxo calcinados e não calcinados. 


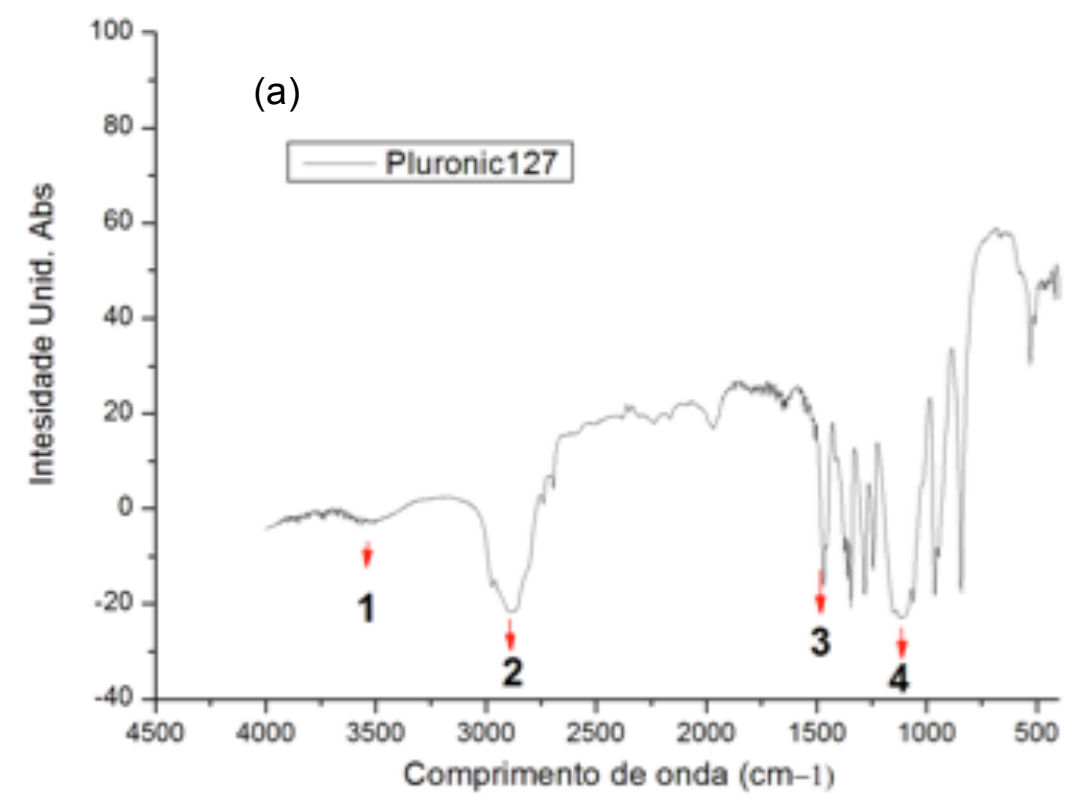

(b)

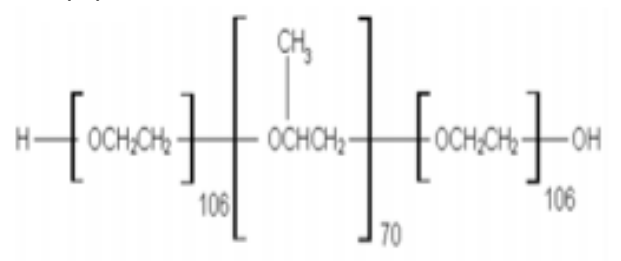

(c)

\begin{tabular}{|c|c|c|}
\hline $\mathbf{N}^{0}$ & $\begin{array}{l}\text { Banda de } \\
\text { absorçalo }\end{array}$ & Grupos funclonals \\
\hline 1 & $3500 \mathrm{~cm}-1$ & estiramento simétrico $\mathrm{OH}$ \\
\hline 2 & $2900 \mathrm{~cm}-1$ & estiramentro simétrico $\mathrm{CH}$ \\
\hline 3 & $1460 \mathrm{~cm}-1$ & $\begin{array}{l}\text { deformação da ligação C- } \\
\mathrm{H} \text { de grupos } \mathrm{CH} 2\end{array}$ \\
\hline 4 & $1103 \mathrm{~cm}-1$ & $\begin{array}{l}\text { deformação da ligação de } \\
\text { grupos C-O (éter). }\end{array}$ \\
\hline
\end{tabular}

Figura 17 . (a) Espectro de infravermelho do pluronic 127. (b) Estrutura química do P127. (c) Grupos funcionais do P127

Pode-se observar que o procedimento de remoção do surfactante é determinante na obtenção de pós mesoporoso com ausência de P127 nos produtos finais. A Figura 18 compara os espectros obtidos nas mesmas condições das amostras preparadas com dois passos distintos de remoção do surfactante, a saber, lavagem com refluxo em etanol e calcinação à $350^{\circ} \mathrm{C}$ por 4 horas. É verificado que no espectro de infravermelho da amostra submetida a extração etanólica sob refluxo a presença da banda de absorção em $2900 \mathrm{~cm}^{-1}$ relativa ao estiramento $\mathrm{C}-\mathrm{H}$ das porções etéricas etanólicas e propanólica do surfactante. Para calcinação de 4 horas na temperatura à $350^{\circ} \mathrm{C}$ observa-se também a contribuição de absorção relativa a presença do surfactante P127. Pode-se sugerir que a presença desta banda de absorção é devida ao P127 remanescente nas amostras finais. 


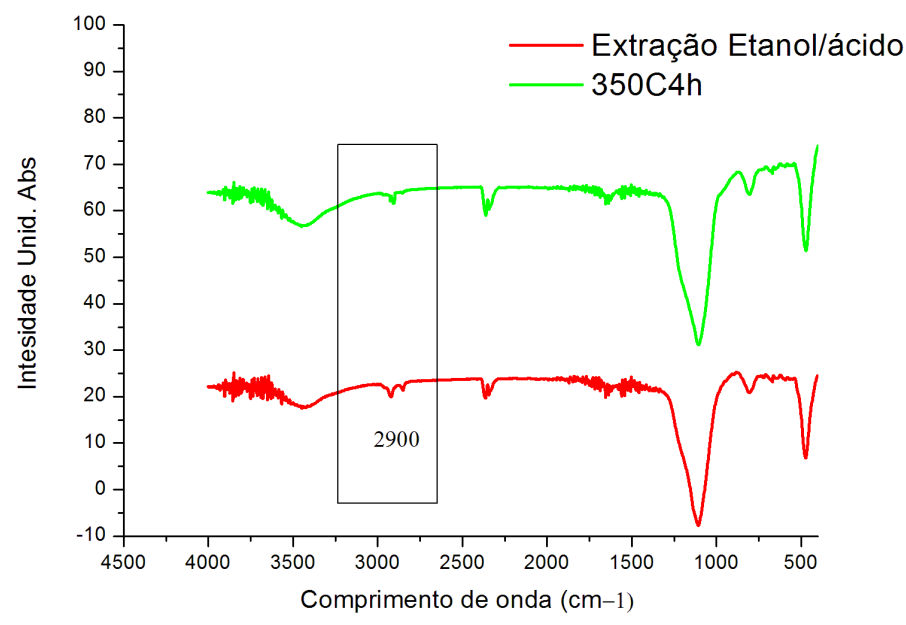

Figura 18. Espectro de infravermelho das amostras removidas com extração sob refluxo em meio $\mathrm{HCL} /$ etanol e calcinadas a $350^{\circ} \mathrm{C}$ por 4 horas.

Adicionalmente, análises de calorimetria exploratória por DSC foram feitas para verificar as ocorrências endotérmicas ou exotérmicas relacionadas com a presença ou ausência do P127. As amostras e o sufarctante foram aquecidos até uma temperatura de $350^{\circ} \mathrm{C}$.

$\mathrm{Na}$ Figura 19 encontram-se as curvas de calorimetria exploratória diferencial do surfactante P127 comparando as amostras preparadas com diferetens teores de TEOS $(0 \%$ à $100 \%)$ submetidos ao método de refluxo $\mathrm{HCl} /$ etanol para a remoção do surfactante. A evolução térmica do P127 mostrada na Figura é composta de dois fenômenos térmicos o primeiro, de natureza endotérmica centrado em $\mathrm{T}=56^{\circ} \mathrm{C}$, e o segundo, de natureza exotérmica centrado em $\mathrm{T}=153^{\circ} \mathrm{C}$, associados, respectivamente à fusão e a decomposição do pluronic. 


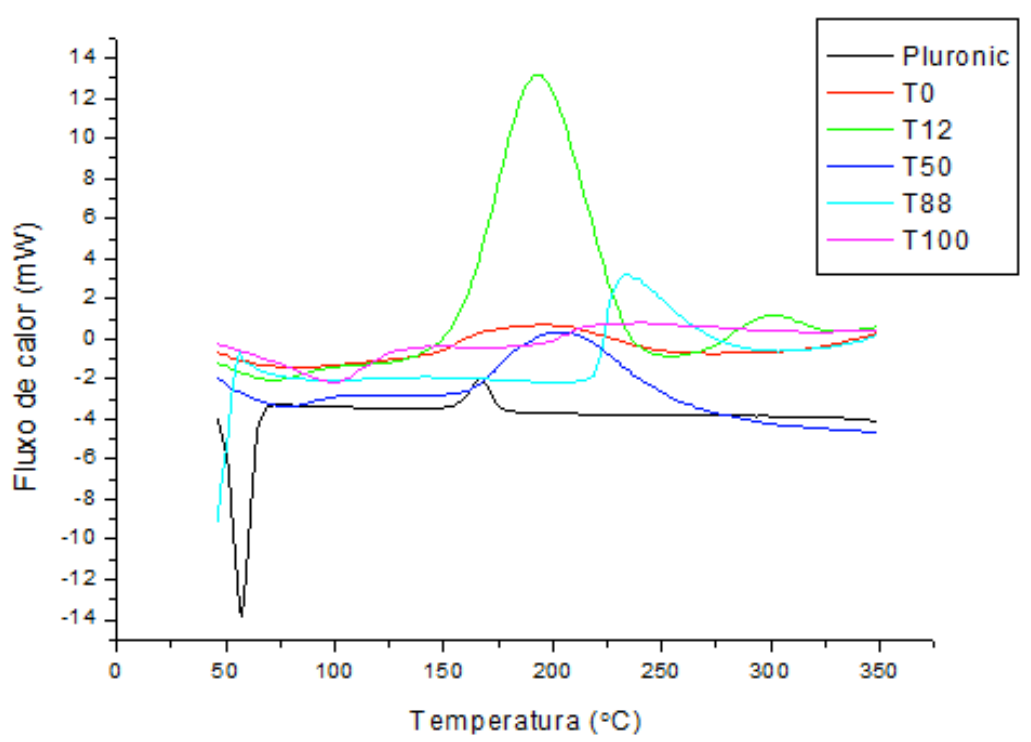

Figura 19. Curvas de DSC do pluronic e das amostras lavadas sob refluxo em meio etanol/Hcl sob uma razão de aquecimento de $20^{\circ} \mathrm{C} \cdot \mathrm{min}^{-1}$, em atmosfera inerte de nitrogênio a $20 \mathrm{~mL} \cdot \mathrm{min}^{-1}$, até uma temperatura de $350^{\circ} \mathrm{C}$.

Conforme já descrito por Couderc et al. (2001) nas amostras preparadas com diferente teores de TEOS submetidas a processo de remoção do surfactante na Figura 19 é verificado os mesmos eventos térmicos, o primeiro em torno de $56^{\circ} \mathrm{C}$ de natureza endotérmica e o segundo em torno de $150^{\circ} \mathrm{C}$. A presença desses picos pode indicar a presença do surfactante remanescente nas amostras finais. Estando de acordo com os resultados obtidos por infravermelho. Pode-se notar que os picos de fusão e de decomposição do pluronic quando misturados nas amostra, ocorrem em temperaturas superiores mesmos eventos térmicos do P127 puro. Este efeito pode estar relacionado ao isolamento térmico conferido pela estrutura silicosa em torno das moléculas do surfactante. Observa-se ainda que o teor de TEOS utilizado na preparação, não exerce influência sobre o processo de remoção do surfactante.

A partir do momento que se constatou que apenas lavagem sob refluxo ou apenas calcinação não eram eficientes para completa remoção do surfactante, partiu-se para associação da lavagem sob refluxo em conjunto ao processo de calcinação. A Tabela 6 abaixo mostra a temperatura de calcinação e o tempo testados associados a lavagem com refluxo. 
Tabela 6. Tratamentos térmicos aplicados na remoção do surfactante.

\begin{tabular}{|cc|}
\hline Temperatura & Tempo \\
\hline $350^{\circ} \mathrm{C}$ & $4 \mathrm{~h}$ \\
\hline $350^{\circ} \mathrm{C}$ & $10 \mathrm{~h}$ \\
\hline $\mathbf{4 5 0 ^ { \circ } \mathrm { C }}$ & $4 \mathrm{~h}$ \\
\hline $\mathbf{5 5 0 ^ { \circ } \mathrm { C }}$ & $4 \mathrm{~h}$ \\
\hline
\end{tabular}

Pode-se observar na Figura 20, que o tempo e temperatura de calcinação, estão correlacionadas a presença da banda de absorção em $2900 \mathrm{~cm}^{-1}$, que é relativa ao estiramento simétrico associados a ligação $\mathrm{C}-\mathrm{H}$. Os procedimentos de calcinação realizados a $350^{\circ} \mathrm{C}$ por 10 horas, $450^{\circ} \mathrm{C}$ e $550^{\circ} \mathrm{C}$ por 4 horas, mostrados na Figura 20, revelam a ausência da banda de absorção relativa ao P127. A ausência de absorção em $2900 \mathrm{~cm}-1$ e também em 1460 e $1103 \mathrm{~cm}^{-1}$ mostraram que não foram identificados bandas relativas ao P127 residual nas amostras tratadas com método de lavagem em refluxo associados a calcinação. É importante ressaltar que a ausência de composto deste tipo é essencial para aplicações biotecnológicas, pois torna o material menos tóxico, além de tornar-lo mais eficiente para a incorporação de moléculas e para sua e liberação sustentada (CABRAL, 2004).

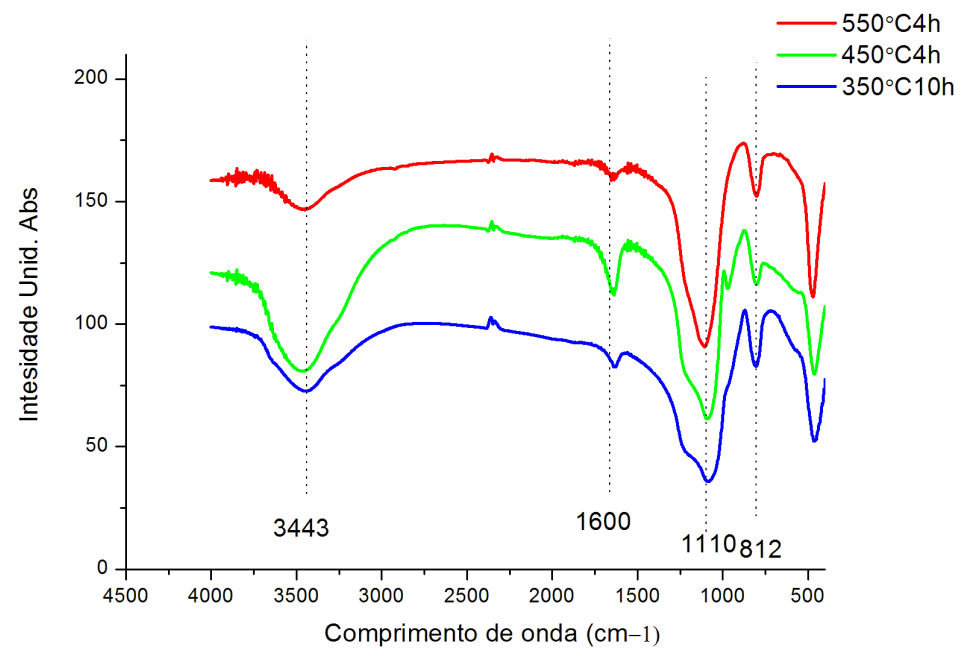

Figura 20. Espectros de absorção na região do infravermelho de amostras T100 submetidas à diferentes métodos de remoção do surfactante.

Pode-se observar também na Figura 20 as absorções relativas aos modos vibracionais dos grupamentos silicosos em 3443, 1600, 1110 e $812 \mathrm{~cm}^{-}$ 
1. As absorções em 3443 e $1600 \mathrm{~cm}^{-1}$ são devidos aos modos vibracionais de estiramento simétrico e deformação axial das ligações $\delta \mathrm{Si}-\mathrm{OH}$, respectivamente. A absorção em $1110 \mathrm{~cm}^{-1}$ é devida ao estiramento assimétrico das ligações $\mathrm{v}$ (ass) Si-O-Si e confirma que o processo de condensação do precursor TEOS foi completo. As absorções principais devidas aos grupamentos siloxanos e suas atribuições mais frequentes são mostrados na Tabela 7 (BARROS et al., 2015).

Tabela 7. Identificação espectrofotométrica de grupos funcionais

\begin{tabular}{|cc|}
\hline Bandas principais & Atribuições \\
\hline$\sim 3550-3100 \mathrm{~cm}^{-1}$ & $v(\mathrm{~s}) \mathrm{H}-\mathrm{O}-\mathrm{H}, \mathrm{v}(\mathrm{s}) \mathrm{Si}-\mathrm{OH}$ \\
\hline$\sim 1640 \mathrm{~cm}^{-1}$ & $\delta \mathrm{Si}-\mathrm{OH}$ \\
\hline$\sim 1080-1160 \mathrm{~cm}^{-1}$ & $\mathrm{v}(\mathrm{ass}) \mathrm{Si}-\mathrm{O}-\mathrm{Si}$ \\
\hline$\sim 810 \mathrm{~cm}^{-1}$ & $\mathrm{v}(\mathrm{s}) \mathrm{Si}-\mathrm{O}-\mathrm{Si}$ \\
\hline
\end{tabular}

Além da remoção do surfactante um outro parâmetro que deve-se controlar no preparo de óxidos meosporosos aplicados na liberação sustentada de princípios ativos, é a cristalinidade. O controle da cristalinidade garante a intensidade dos poros. $O$ tratamento térmico favorece a coalescência dos grãos e o fechamento dos poros. Amostras submetidas à diferentes tratamentos de remoção do surfactante, a saber: refluxo com $\mathrm{HCl} /$ etanol e calcinação à $350^{\circ} \mathrm{C}$, $450^{\circ} \mathrm{C}$ e $550^{\circ} \mathrm{C}$ foram avaliadas por diafratometria de raios $x$ e adsorção e dessorção de nitrogênio visando a correlação entre a temperatura de tratamento térmico e as característica porosimétricas relevantes.

A Figura 21 mostram os difratogramas para amostras submetidas a refluxo $\mathrm{HCl} /$ etanol e tratadas termicamente à $350^{\circ} \mathrm{C}, 450^{\circ} \mathrm{C}$ e $550^{\circ} \mathrm{C}$. Pode-se observar que as amostras tratadas termicamente à $450^{\circ} \mathrm{C}$ e $550^{\circ} \mathrm{C}$ apresentam picos de difração mais intensos em $2 \theta$ igual $22^{\circ}, 27^{\circ}, 32^{\circ}$ e $45^{\circ}$. A amostra calcinada a $550^{\circ} \mathrm{C}$ possui picos adicionais $29^{\circ}, 34^{\circ}$ e $40^{\circ}$. Os picos de difração observados estão indexados na Figura 21 e podem ser atribuídos as difrações referentes a fase de cristobalita. Porém, no difratograma da amostra, tratada sob refluxo em meio $\mathrm{HCl} /$ etanol e tratada sob refluxo em meio $\mathrm{HCl} /$ etanol e 
tratada termicamente à $350^{\circ} \mathrm{C}$ por $10 \mathrm{~h}$, não se observa as contribuições relativas às difrações do óxido silício.

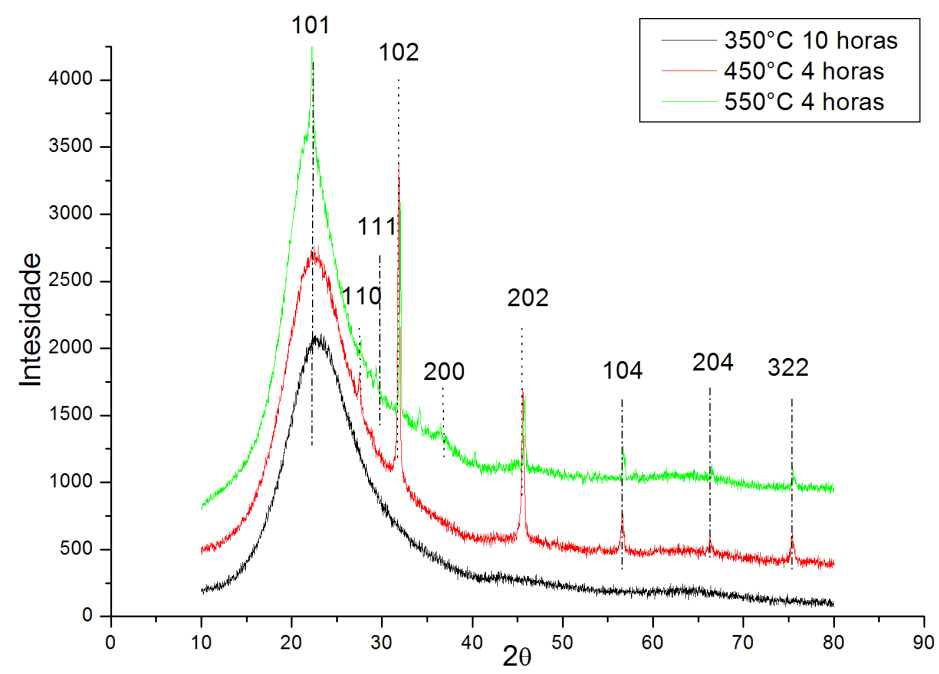

Figura 21. Difratogramas de raios $X$ de amostra $T 100$ submetidas a lavagem sob refluxo $\mathrm{HCl} /$ etanol e tratadas termicamente em diferentes temperaturas.

No entanto, segundo autores (ZHAO,1998) altas temperaturas de calcinação podem afetar não somente a estrutura cristalina do oxido de silício, conforme discutido acima, bem como a alterar também a porosidade e a fase dos materiais resultantes. Assim, para avaliar a porosidade das amostras realizou-se as análises de adsorção e dessorção de nitrogênio medidas na faixa de pressão relativa de P/P0 de 0,01 a 0,20.

A Figura 22 (a), (b) e (c) mostram as isotermas de adsorção/dessorção de nitrogênio para amostras tratadas com diferentes procedimentos de tratamentos térmicos do surfactante. A Figura 22 (a) (b) e (c) mostram as isotermas de adsorção de nitrogênio tratadas termicamente à $350^{\circ} \mathrm{C}, 450^{\circ} \mathrm{C} \mathrm{e}$ $550^{\circ} \mathrm{C}$, respectivamente. De acordo com a IUPAC os formatos das isotermas podem ser usadas para classificar a porosidade de materiais. A isoterma da amostra tratada termicamente à $350^{\circ} \mathrm{C}$, mostrada na Figura 22 (a), pode ser classificada como típica de materiais mesoporosos, com poros variando de 2 à $50 \mathrm{~nm}$. Neste tipo de isoterma a curva de histerese apresenta a curva de dessorção paralela ao eixo das ordenadas o que está associado ao ordenamento homogêneo da rede porosa. A isoterma da amostra tratada termicamente à $450^{\circ} \mathrm{C}$ pode ser observada na Figura 22 (b). É verificado um aumento da quantidade absorvida de nitrogênio em relação à pressão relativa 
$\left(P / P_{0}\right)$. Segundo a IUPAC este perfil de isoterma pode ser características de materiais macro porosos ou não porosos do tipo III. Enquanto que a isoterma da amostra tratada termicamente à $550^{\circ} \mathrm{C}$, mostrada na Figura 22 (c), pode ser classificada como típica de materiais não porosos do tipo I, com ausência completa de ciclo de histerese.

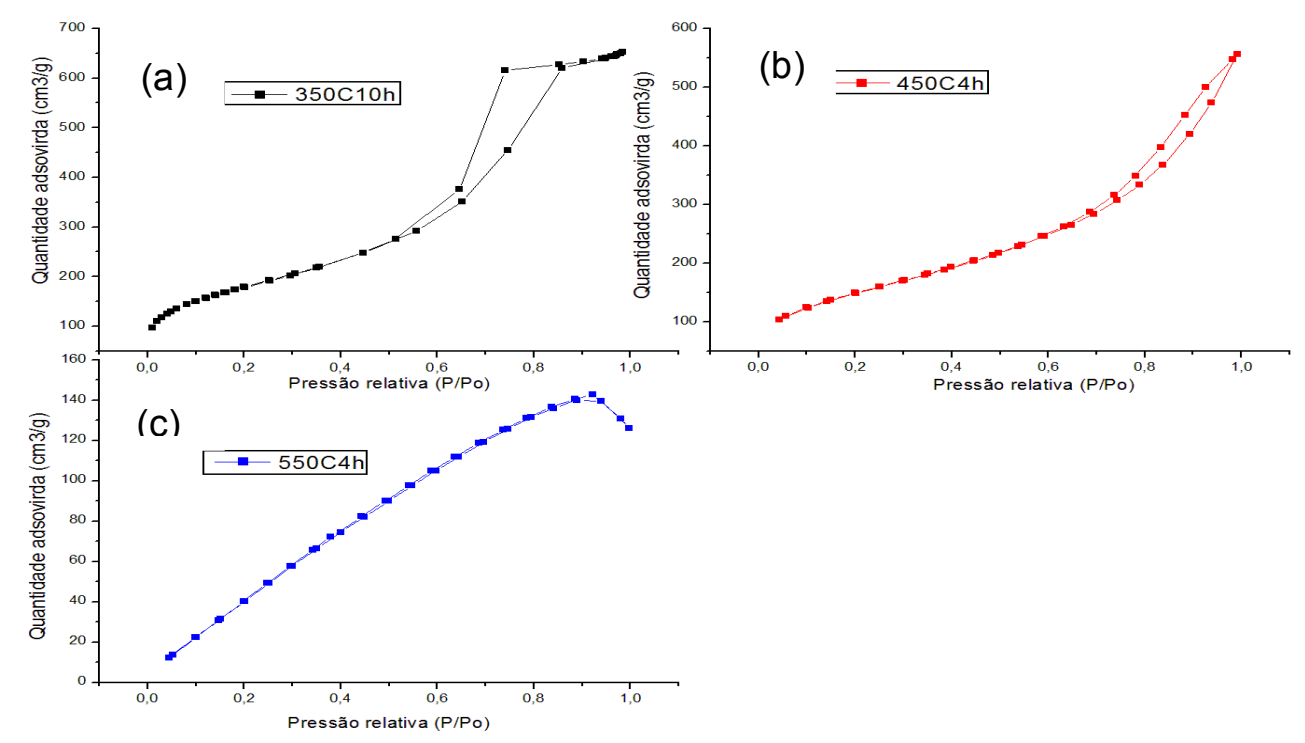

Figura 22. Isotermas de adsorção/dessorção das amostras calcinadas em diferentes temperaturas. (a) $305^{\circ} \mathrm{C}$, (b) $450^{\circ} \mathrm{C}$ e (c) $550^{\circ} \mathrm{C}$.

Os resultados calculados a partir das curvas de isotermas utilizando-se 0 método de Brunauer-Emmett-Teller (BET), podem ser vistos na Tabela 8. Observa-se que temperaturas mais elevadas de calcinação resultam na diminuição tanto da área de superfície, como do volume e raios de poro. As amostras submetidas a tratamentos térmicos à $350^{\circ} \mathrm{C}$, a área de superfície e volume dos poros foram de $643,5 \mathrm{~m} 2 / \mathrm{g}$ e 1,04cc/g. Enquanto que calcinações em temperaturas de $450^{\circ} \mathrm{C}$ e $550^{\circ} \mathrm{C}$ a área de superfície foi de $535,5 \mathrm{~m} 2 / \mathrm{g} \mathrm{e}$ $256 \mathrm{~m} 2 / \mathrm{g}$ e volume de $0,73 \mathrm{cc} / \mathrm{g}$ e $0,18 \mathrm{cc} / \mathrm{g}$, respectivamente. 
Tabela 8 Resultados do Bet em relação a temperatura e fechamento dos poros.

\begin{tabular}{|c|c|c|c|c|c|c|c|}
\hline \multirow{2}{*}{$\begin{array}{l}\text { Tratamento } \\
\text { térmico }\end{array}$} & \multicolumn{3}{|c|}{ Área de superficie $\left(\mathrm{m}^{2} / \mathrm{g}\right)$} & \multicolumn{2}{|c|}{ Volume poro(cc/g) } & \multicolumn{2}{|c|}{ Raio do poro $(\hat{A})$} \\
\hline & $\begin{array}{l}\text { BJH } \\
\text { adsorcao }\end{array}$ & $\begin{array}{l}\text { BJH } \\
\text { dessorção }\end{array}$ & Bet & $\begin{array}{l}\text { BJH } \\
\text { adsorcao }\end{array}$ & $\begin{array}{l}\text { BJH } \\
\text { dessorção }\end{array}$ & $\begin{array}{l}\text { BJH } \\
\text { adsorcao }\end{array}$ & $\begin{array}{l}\text { BJH } \\
\text { dessorção }\end{array}$ \\
\hline $350^{\circ} \mathrm{C} .10 \mathrm{~h}$ & 841,7 & 757,5 & 643,5 & 1,04 & 1,03 & 55 & 49 \\
\hline $450^{\circ} \mathrm{C} .4 \mathrm{~h}$ & 313,8 & 322,2 & 535,5 & 0,73 & 0,72 & 15,2 & 23,6 \\
\hline $550^{\circ} \mathrm{C} .4 \mathrm{~h}$ & 152,1 & 134,6 & 256,8 & 0,18 & 0,17 & 15,2 & 16,5 \\
\hline
\end{tabular}

Os resultados BET para as amostras tratadas em diferentes temperaturas mostram que temperaturas mais elevadas de calcinação há uma contração na estrutura porosa formando uma estrutura mais densificada, e resultando em uma área, volume e raio de poros menores quando calcinados à temperatura superior de $450^{\circ} \mathrm{C}$.

Segundo estudos, diversos fatores podem alterar a estrutura porosa dos silicatos de mesoporos, tais como: concentração de TEOS, pH, tempo e temperatura de agitação, envelhecimento e calcinação (ZHAO, 1998a; ZHAO, 1998b; ZHAO, 2010).

A partir dos resultados do estudo da remoção do $\mathrm{P} 127$, o método de eliminação do surfactante foi definido em uma primeira extração do P127 sob refluxo em meio $\mathrm{HCl} /$ etanol, e posteriormente calcinado a uma temperatura de $350^{\circ} \mathrm{C}$ por 10 horas.

A fim de se confirmar se o processo de remoção do surfactante escolhido, a saber lavagem sob refluxo em $\mathrm{HCl} /$ etanol e calcinação à $350^{\circ} \mathrm{C}$ por 10 horas, foram realizados medidas de absorção de infravermelho e difração de raios $X$, para a série completa de amostras preparadas com diferentes teores de TEOS $(0,12,50,88$ e 100\%) conforme apresentado nas Figuras 23 e 24, respectivamente. Como pode-se observar as curvas de absorção infravermelho não apresentam a contribuição relativas ao surfactante em $2900 \mathrm{~cm}^{-1}$ e os difratogramas não mostram picos de difração de siloxano cristalino. Conforme observado na Figura 24 as amostras tratadas termicamente a $350^{\circ} \mathrm{C}$ por 10 horas apresentaram um pico alargado na varredura de $2 \theta$ igual a $22^{\circ}$ relativas ao óxido de silício amorfo cristalino finais. Estes resultados indicam que independentemente do teor de TEOS usados no preparo das amostras, o processo de remoção do surfactante adotado é eficiente não resultando em 
surfactante remanescente nem formação de monocristais de óxido de silício com a manutenção da porosidade.

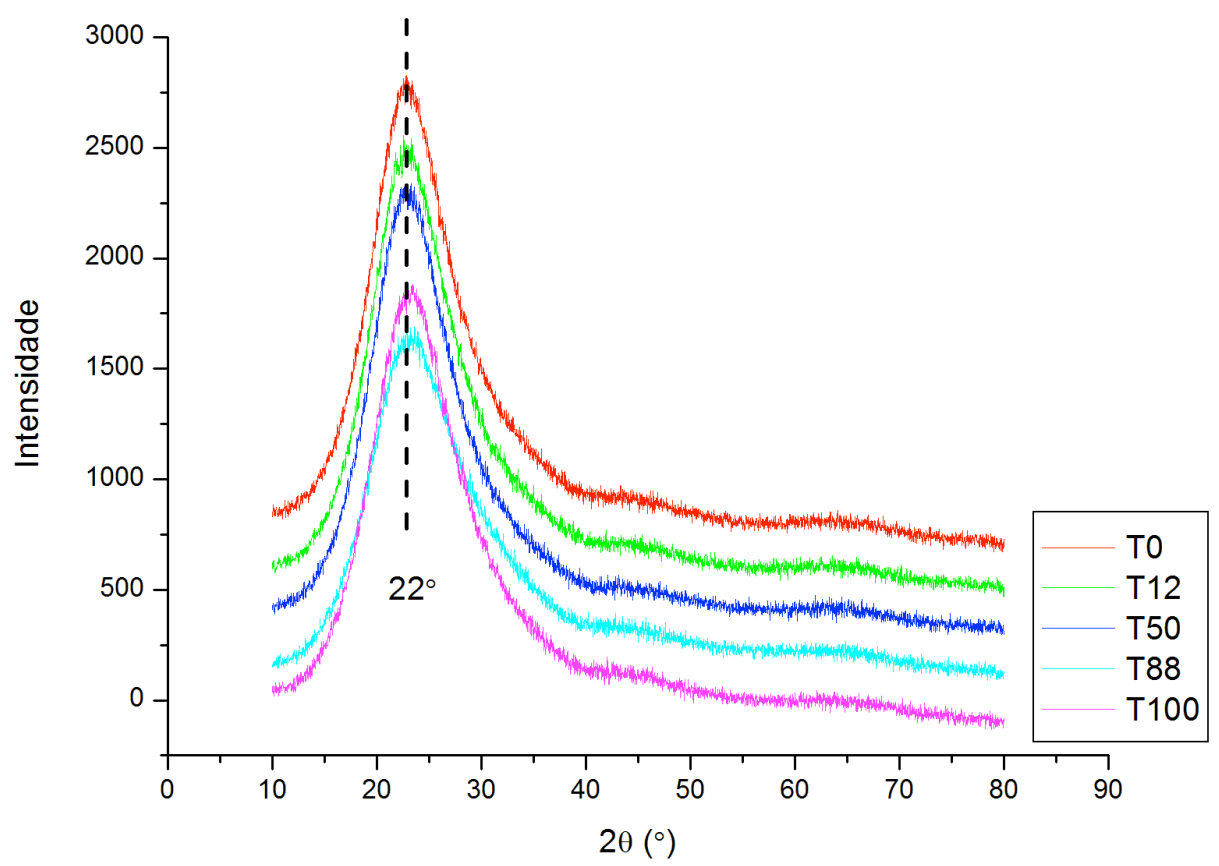

Figura 23. Curvas de espectroscopia no infravermelho das amostras estudados tratadas termicamente a $350^{\circ} \mathrm{C}$ por 10 horas.

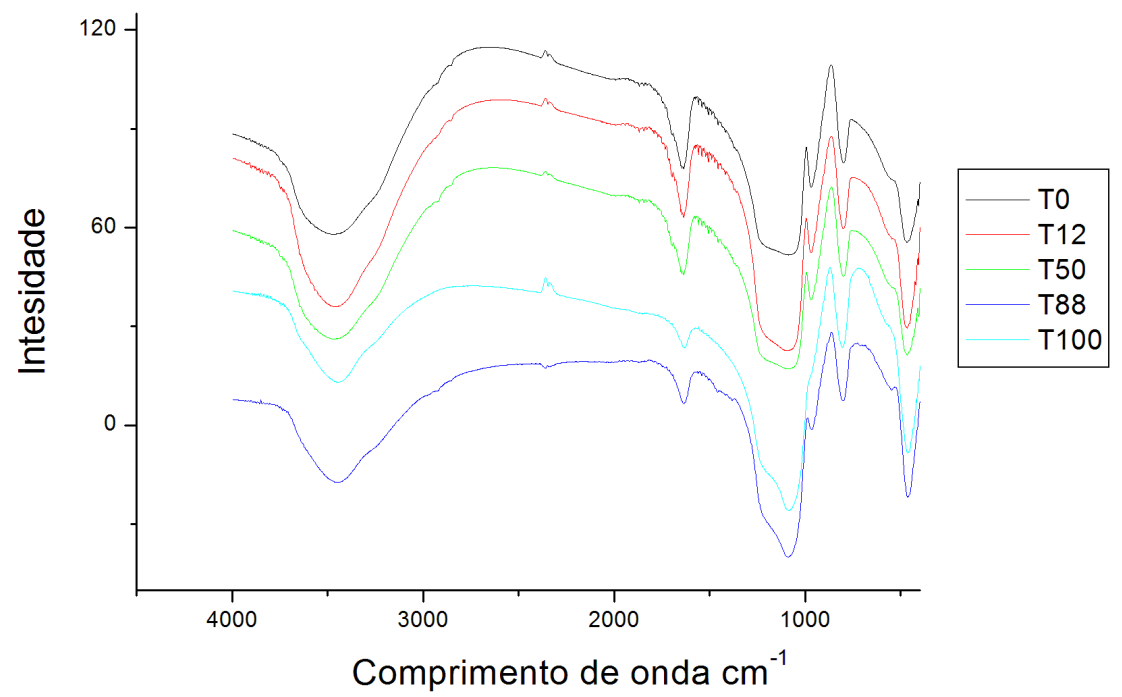

Figura 24. Difratogramas de raios $X$ das fontes de sílica calcinada em à $350^{\circ} \mathrm{C}$ por 10 horas.

Para verificar os parâmetros texturais como área específica, diâmetro médio de poro e volume de poro foram obtidos através de experimentos de adsorção/dessorção de nitrogênio. $O$ cálculo da área específica foi realizado a 
partir da isotermas de adsorção de $\mathrm{N}^{2}$ utilizando-se o método nas mesmas condições descritas.

Na Figura 25 (a), (b), (c), (d) e (e) encontram-se as curvas de isotermas adsorção/dessorção de nitrogênio das amostras com teores de TEOS nos intervalos de $0 \%, 12 \%, 50 \%, 85 \%$ e $100 \%$ usados nas sínteses dos materiais, respectivamente.

As isotermas de adsorção de nitrogênio das amostras são caracterizadas de acordo com a IUPAC como uma isoterma do tipo IV, a qual é típica de materiais porosos na faixa de mesoporos, compreendidos entre 2 e 50 nm (20$500 \AA$ ). Observa-se uma histerese típica desses materiais, os quais apresentam uma curva de dessorção paralelo aos valores da ordenada, classificados como $\mathrm{H} 2$, visto em região de pressão relativamente alta ( $P / P o=0,5-1)$, que é um indicativo da homogeneidade da rede porosa em relação ao arranjo de poros (GOBIN, 2006). Verifica-se que o perfil das isotermas não foi alterado pela variação das fontes de sílica, preservando as características estruturais da matriz mesoporosa.
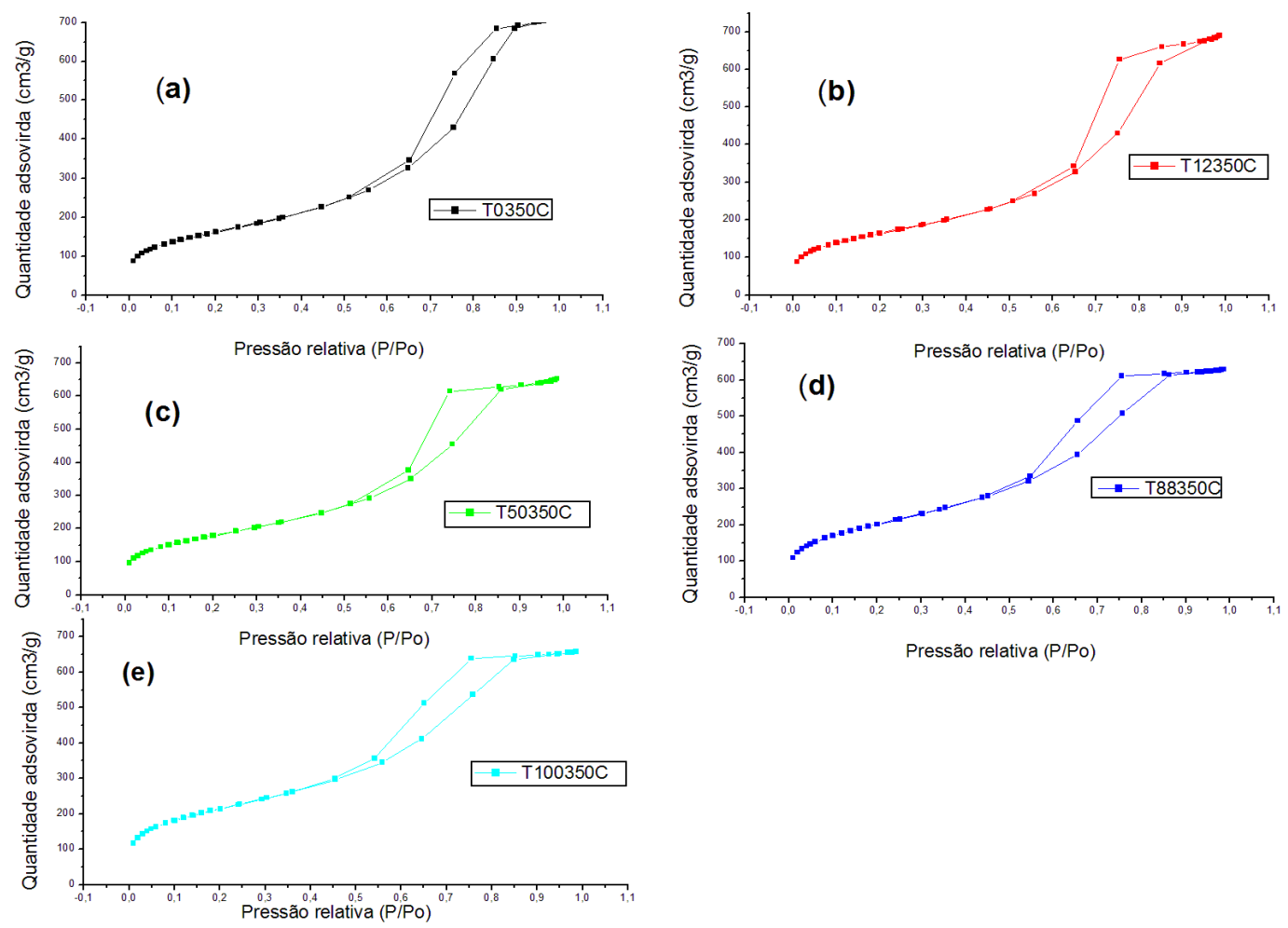

Figura 25. Curvas de isotermas dos materiais mesoporosos calcinados a $350 \mathrm{C}$ por 10 horas.

A partir desses resultados obtidos pelo material de BET é possível confirmar a presença da formação de um material mesoestruturado como foi 
previamente esperado.

$\mathrm{Na}$ Tabela 9 estão apresentados os resultados do BET das amostras com variações percentuais das fontes de sílica, a saber TEOS e silicato de sódio, calcinadas a $350^{\circ} \mathrm{C}$ por 10 horas. Pode-se observar na tabela g que a área de superfície dos mesoporosos variou em $770 \mathrm{~m}^{2} / \mathrm{g}, 726 \mathrm{~m}^{2} / \mathrm{g}, 643 \mathrm{~m}^{2} / \mathrm{g}, 590 \mathrm{~m}^{2} / \mathrm{g}$ e $581 \mathrm{~m}^{2} / \mathrm{g}$ na presença de $100 \%, 88 \%, 50 \%, 12 \%$ e $0 \%$ de TEOS, respectivamente.

Tabela 9. Resultados da adsorção/dessorção das amostras calcinadas a 350C por 10 horas.

\begin{tabular}{|cccccc|}
\hline Amostras & Area de superficie $\left.\mathbf{~ ( m}^{\mathbf{2}} \mathbf{g}\right)$ & \multicolumn{2}{c}{ Volume do poro(cc/g) } & \multicolumn{2}{c|}{ Raio do poro (A) } \\
& Bet & $\begin{array}{c}\text { BJH } \\
\text { adsorção }\end{array}$ & $\begin{array}{c}\text { BJH } \\
\text { dessorção }\end{array}$ & $\begin{array}{c}\text { BJH } \\
\text { adsorção }\end{array}$ & $\begin{array}{c}\text { BJH } \\
\text { dessorção }\end{array}$ \\
\hline T100 & 770,7 & 1,06 & 1,05 & 49 & 42,8 \\
\hline T88 & 726,3 & 1,02 & 1,0 & 48,7 & 42,9 \\
\hline T50 & 643,5 & 1,04 & 1,03 & 55 & 49 \\
\hline T12 & 590 & 1,09 & 1,08 & 62,7 & 56,4 \\
\hline T0 & 581,7 & 1,1 & 1,08 & 64 & 63 \\
\hline
\end{tabular}

A Figura 26 mostra a curva da concentração de TEOS em função da área de superfície. Nota-se que há um aumento na área de superfície quando os percentuais de TEOS são maiores.

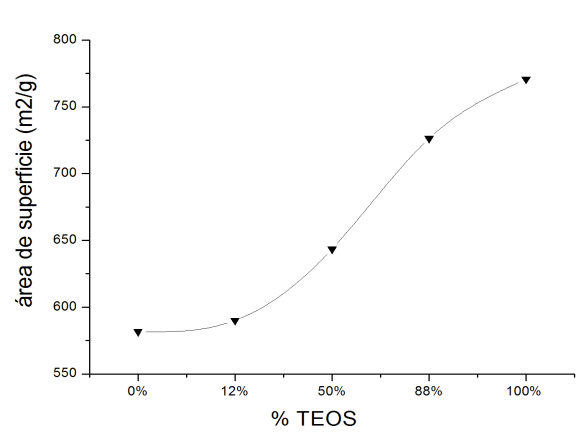

Figura 26. curva da área de superfície em função das concentrações de $0 \%, 12 \%, 50 \%$, $88 \%$ e $100 \%$ de TEOS.

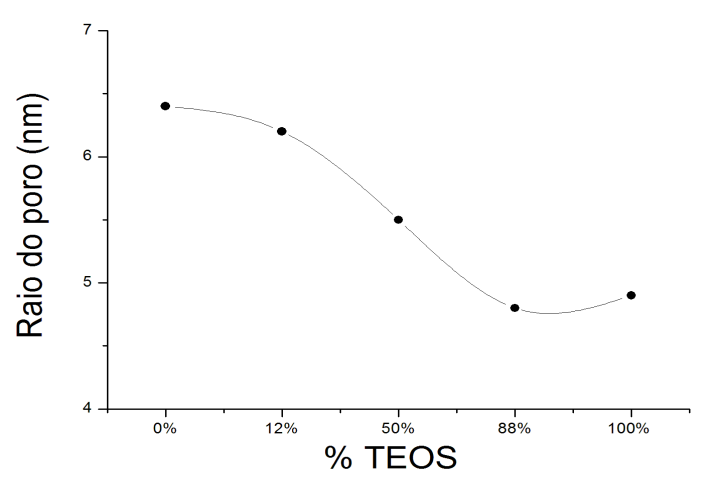

Figura 27. curva do raio dos poros em função das concentrações de $0 \%, 12 \%, 50 \%, 88 \%$ e $100 \%$ de TEOS.

No entanto, em relação ao tamanho do raio do poros os resultados apresentaram uma relação inversa a concentração de TEOS descrita acima.

Na Figura 27 mostra a distribuição de tamanho do raio dos poros das 
amostras calcinadas a $350^{\circ} \mathrm{C}$ por 10 horas. Para as amostras T0, T12 e T50 o tamanho do pico máximo encontra-se em torno de $6,5 \mathrm{~nm}$, enquanto que as amostras T88 e T100 apresentam o pico em 4,8 nm. Esses resultados corroboram com alguns estudos (LI, 2006; LIU, 2007) que apontam que as diferentes concentrações de TEOS influenciam na estrutura porosa de materiais mesoporosos.

Após as análises de BET e difração de raios $X$ a ângulos rasantes, descritas a seguir, pode-se obter os valores do parâmetro de célula unitária $a^{0}$ e diâmetro dos poros, respectivamente. O cálculo de espessura da parede de poros das amostras, pode ser obtido através da equação (10).

Para os valores encontrados da espessura da parede dos poros dos materiais estudados, observa-se diferentes resultados relacionados com as concentrações de TEOS e silicato de sódio usados nas sínteses das sílicas mesoporosas. Na Tabela 10 estão representados os valores do diâmetro dos poros calculado pelo método BJH e a espessura da parede dos poros das amostras com $0 \%, 12 \%, 50 \%, 88 \%$ e $100 \%$ de TEOS. Percebe-se que quanto maior o teor de TEOS o diâmetro e espessura dos poros diminuem.

Tabela 10 Valores do diâmetro e espessura da parede dos poros das amostras calcinadas à $350^{\circ} \mathrm{C}$ por 10 horas.

\begin{tabular}{|ccc|}
\hline Amostras & Diâmetro dos poros $(\mathbf{n m})$ & $\begin{array}{c}\text { Espessura da parede dos } \\
\text { poros }(\mathbf{n m})\end{array}$ \\
\hline T0 & 12,7 & 4,5 \\
\hline T12 & 11,9 & 3,4 \\
\hline T50 & 10,4 & 1,95 \\
\hline T88 & 9,1 & 0,65 \\
\hline T100 & 9,1 & 0,65 \\
\hline
\end{tabular}

Cheng et al. (2003) apresentaram a espessura de parede na ordem de 8,5-9,1 $\mathrm{nm}$ denominando a espessura de parede de poros do SBA-16 como ultra-grossa, quando comparadas a sistemas hexagonais, tal como o SBA-15, que apresenta valores da ordem de $5,5 \mathrm{~nm}$. Na Tabela 10 pode-se observar que a parede dos poros possuem uma espessura fina diferentemente dos resultados apresentados na literatura.

A partir dos estudos realizados nesse trabalho descritos acima, foi 
possível obter um material poroso, livre do surfactante com potencial para o carregamento de componentes bioativos e para servir de veículo para a entrega de drogas com uma liberação sustentada.

\subsection{Do ordenamento, morfologia e carga de superfície dos poros.}

Para avaliar e estudar as características porosimétricas e de superfície dos materiais obtidos pela metodologia de remoção do surfactante definida, foram realizadas também medidas de difração de raios $X$ à ângulos rasantes.

As análises de difração de raios $\mathrm{X}$ a ângulos rasantes foram conduzidas com $2 \theta$ entre $0,2^{\circ}-4^{\circ}$ graus, a fim de detectar o ordenamento do arranjo periódico dos poros, e suas característica como distância entre poros e tamanho da parede dos poros.

A Figura 28 mostra a curva de raios $x$ ângulo rasantes com $2 \theta$ entre $0,2^{\circ}$ $4^{\circ}$ graus para amostras preparadas com diferentes teores de TEOS, a saber $0 \%, 12 \%, 50 \%, 88 \%$ e $100 \%$. Pode-se observar a presença de um pico de difração $2 \theta$ igual $0,47^{\circ}$ correspondente ao plano (110). Essa reflexão indica que o ordenamento dos poros apresenta uma estrutura cúbica de corpo centrado, de grupo espacial Im3m (GRUDZIEN, 2006b; BALLEM, 2010). A partir da distância interplanar obtida pela equação de Bragg (8) de 3,42nm pode-se determinar o parâmetro de célula unitária $a^{0}$ de $8,45 \mathrm{~nm}$, encontrado pela equação (9). 


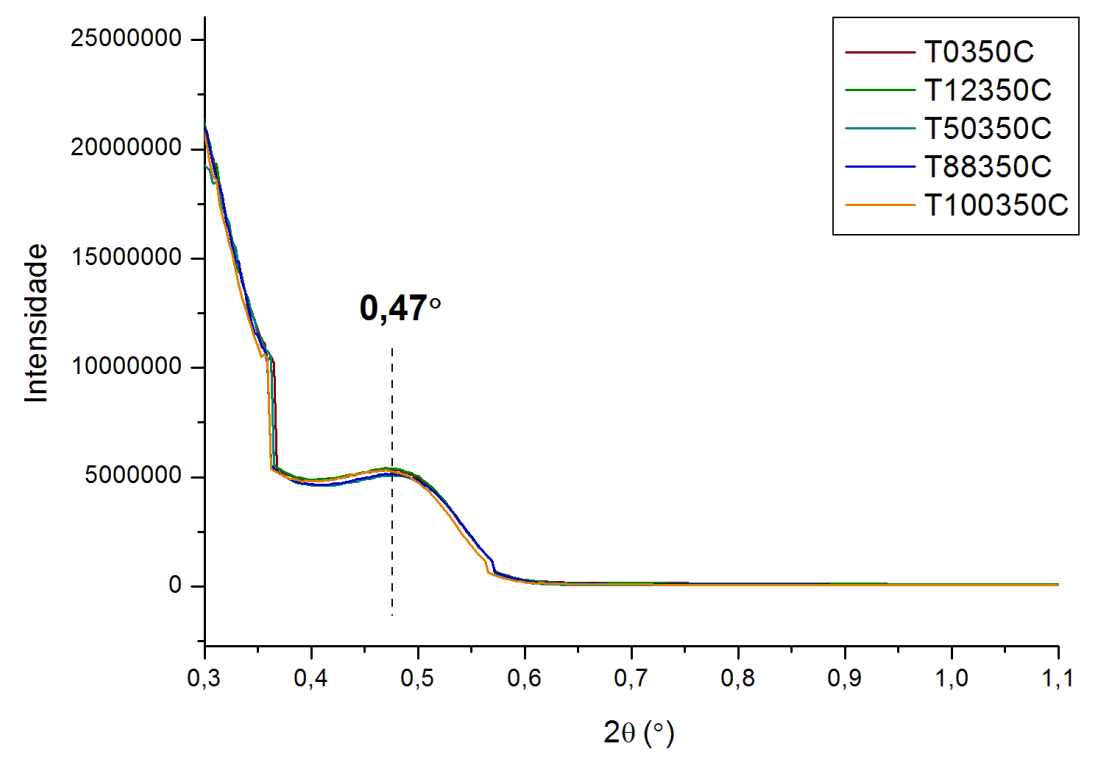

Figura 28. Curva de difratogramas de raios $X$ a baixo angulo das amostras calcinadas a $350^{\circ} \mathrm{C}$ por 10 horas.

Observa-se na micrografia de transmissão de alta resolução que esses valores estão de acordo com os obtidos por MET mostrados na figura 29. Ademais, os materiais obtidos possuem tamanho de poros bem definidos e elevada área superficial, sendo essas características evidenciadas pelas análises descritas anteriormente nesse trabalho.

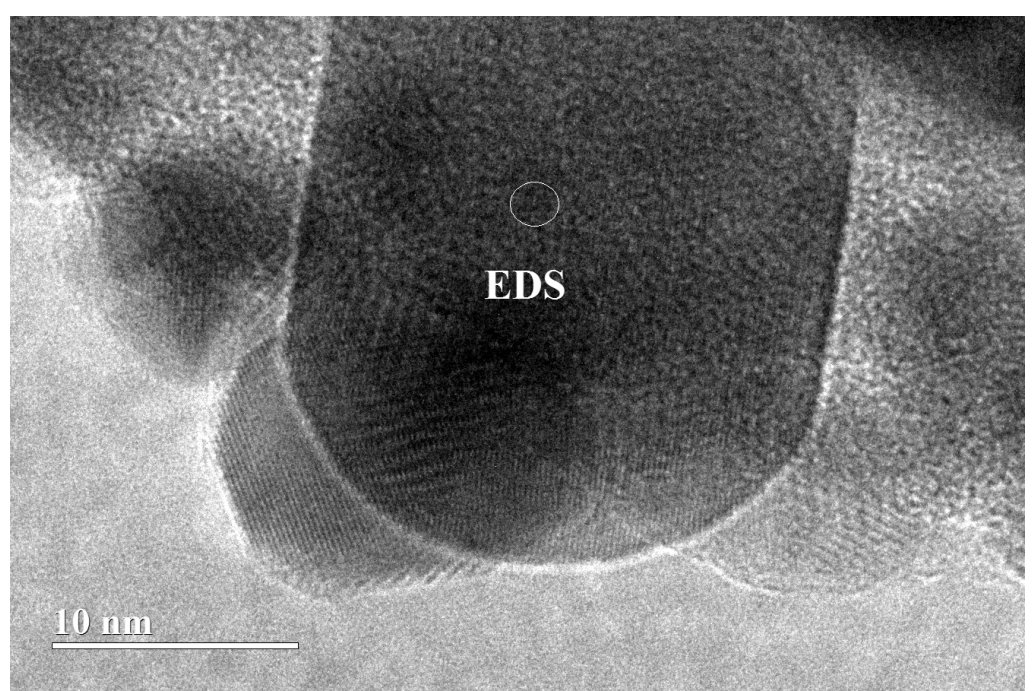

Figura 29. Imagem de microscopia eletrônica de transmissão dos silicatos de mesoporosos em uma escala de 10 nanômetros.

A Figura 30 representa as análises de EDS realizada nas amostras pela 
microscopia eletrônica de transmissão. Observa-se uma alta concentração de silício encontrado nas amostras o que confirma a composição dos silicatos de mesoporosos sintetizados e estudados.

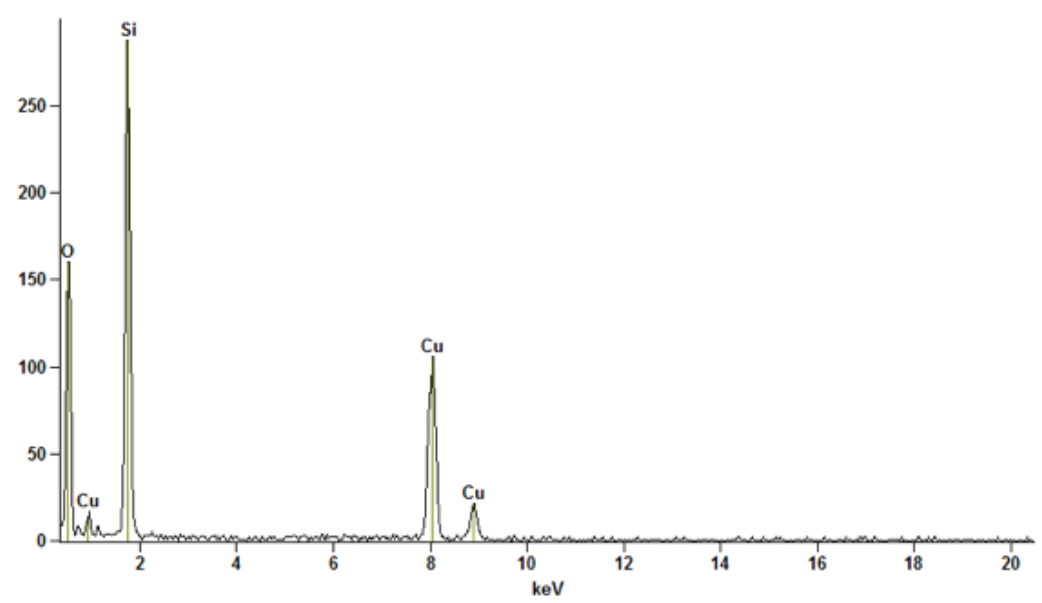

Figura 30. Gráfico referente a composição dos silicatos estudos por microscopia eletrônica de transmissão.

Nas Figuras 31 (a), (b) e (c) econtram-se as imagens de MEV estudadas em uma escala de 5000nm. Pode-se observar um tamanho e forma das partículas de tamanhos variados, sugerindo que não há uniformidade nos mesoporosos obtidos. De acordo com Figuras 31 (a), (b) e (c) das imagens de MEV o tamanho das amostras com $0 \%, 50 \%$ e $100 \%$ de TEOS foram de aproximadamente $3000 \mathrm{~nm}, 2000 \mathrm{~nm}$ e $1500 \mathrm{~nm}$, respectivamente. Sugere-se que a concentração de TEOS e silicato influenciam no tamanho dos mesoporosos, corroborado por Liu et al. 2007.

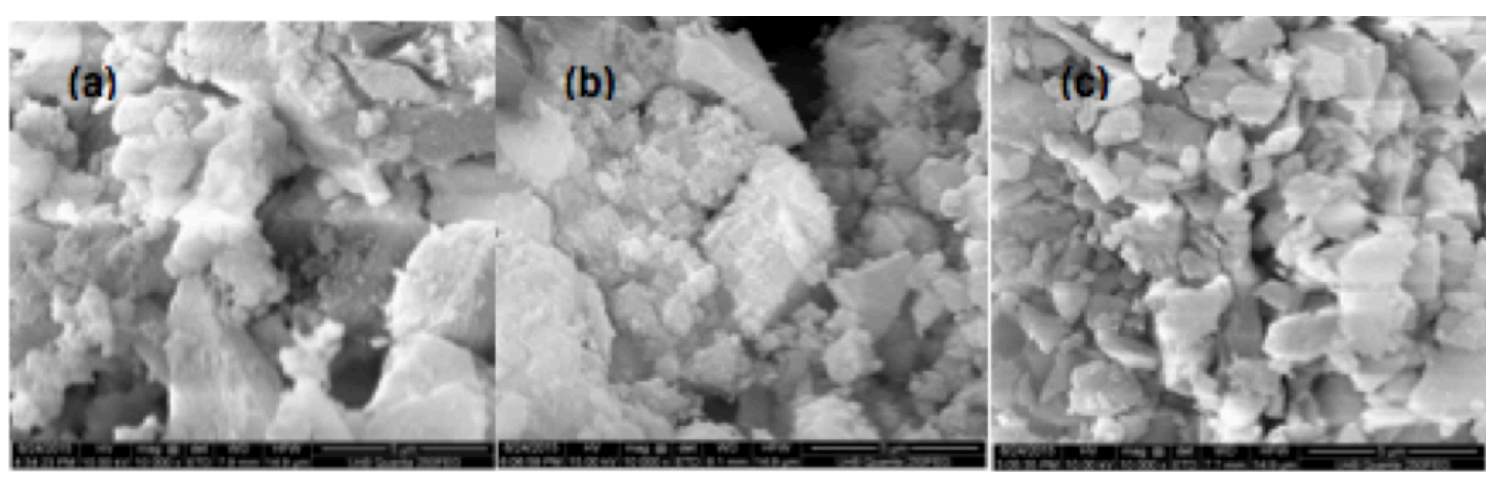

Figura 31. Imagem de microscopia eletrônica de varredura da amostras T0, T50 e T100.

A Figura 32 (a) e (b) mostram as imagens das amostras T0, T88 e na Figura 32 (c) a amostra T100 em uma escala de $200 \mathrm{~nm}$ e $100 \mathrm{~nm}$, 
respectivamente. Podemos observar que o material apresentou morfologia homogênea, com a presença de agregados esféricos. Esses resultados estão de acordo com as microscopia de varreadura eletrônica realizadas por Shah et al. (2014) e Barros et al. (2015).

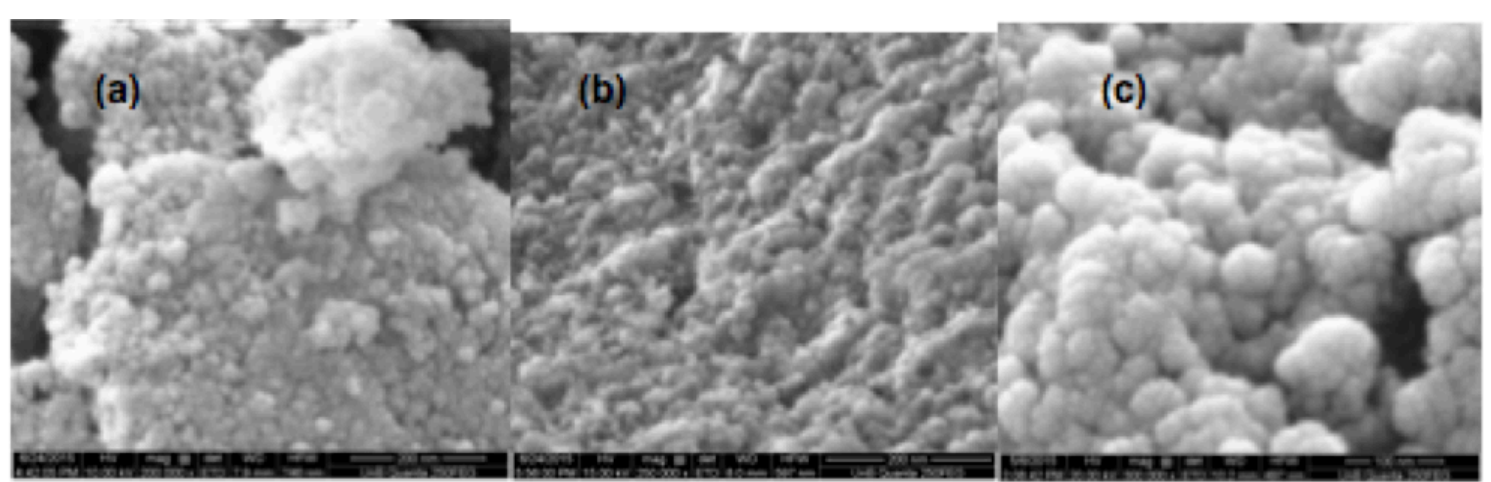

Figura 32. Imagem de microscopia eletrônica de varredura das amostras T0, T88 e T100.

Os mesoporosos foram analisadas quanto à carga superficial em função da alteração do $\mathrm{pH}$. As amostras foram diluídas em água deionizada a concentração de $0,001 \mathrm{mg} / \mathrm{ml}$ e medidas no equipamento Marevan zeta size Nano.

A Figura 33 mostra a variação da carga de acordo com o valor de $\mathrm{pH}$. Em todos os materiais calcinados a $350^{\circ} \mathrm{C}$ por $10 \mathrm{~h}$, pode-se observar que quanto maior o pH menor a carga dos mesoporosos não tendo diferença significativa entre as amostras.

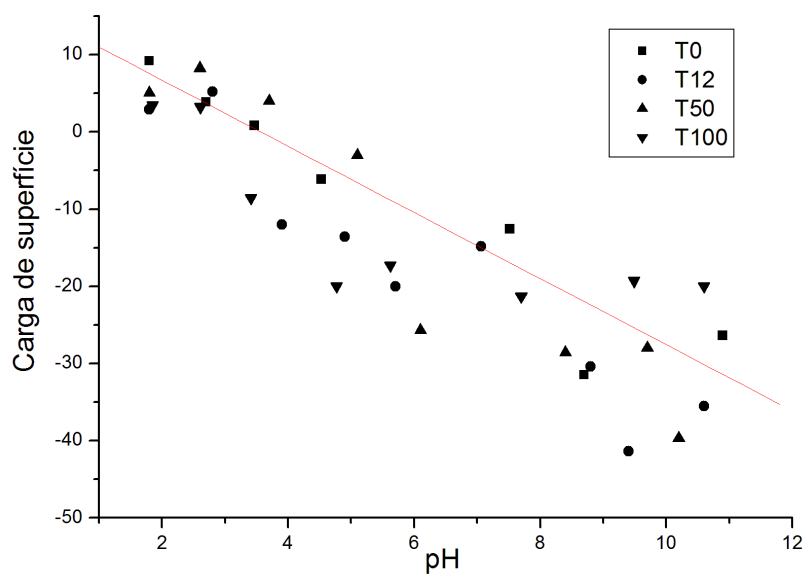

Figura 33. Curvas das cargas de superfícies das amostras com $0 \%, 12 \%, 50 \%$ e $100 \%$ de TEOS calcinadas à $350^{\circ} \mathrm{C}$ por 10 horas. 
A carga sobre a superfície das nanopartículas podem desempenhar um papel importante na sua biodistribuição (HUANG, 2011). Neste trabalho, como discutido, as amostras apresentaram cargas de superfície negativas em um pH acima de 2,5. Esses materiais podem sofrer modificações químicas que alteram sua carga de superfície para uma carga positiva o que aumenta a endocitose dos mesoporosos impregnados (VALLET- REGÍ, 2007b). Dessa maneira, é possível uma maior interação dos silicatos de mesoporosos com células cancerígenas devido suas características aniônicas desses tipos de células (ZHAO, 2010).

\subsection{Estudo da impregnação}

Esse estudo visou confirmar a presença de indol I3C nas matrizes mesoporosas, as amostras foram avaliadas de forma qualitativa a partir dos resultados obtidos de infravermelho e EPR

$\mathrm{Na}$ Figura 34 (a), encontra-se o espectro na região infravermelho do I3C registrados em $400 \mathrm{~cm}-1$ a $4500 \mathrm{~cm}-1$, medidas no modo absorção com auxilio de pastilhas de $\mathrm{KBr}$. Podemos observar na Figura 34, as bandas de absorção que são relativas aos grupos funcionais do $13 \mathrm{C}$ presentes na região $3390 \mathrm{~cm}^{-1}$, $3050 \mathrm{~cm}^{-1}, 2370 \mathrm{~cm}^{-1}, 1600 \mathrm{~cm}^{-1}, 1580-1486 \mathrm{~cm}-1,1300-1200 \mathrm{~cm}^{-1}, 920 \mathrm{~cm}^{-1} \mathrm{e}$ $720 \mathrm{~cm}^{-1}$, as absorções estão atribuídas na Figura 34 (b) (BILLES et al., 2009). A banda de absorção na região de $3390 \mathrm{~cm}^{-1}$, relaciona-se ao grupo de ligação $\mathrm{N}-\mathrm{H}$ associado em aminas secundárias e as vibração de $3050 \mathrm{~cm}^{-1}$ é relativa a deformação das ligações $\mathrm{C}-\mathrm{H}$ dos anéis aromáticos e serão usadas para identificar o $\mathrm{I} 3 \mathrm{C}$ nas amostras impregnadas. 


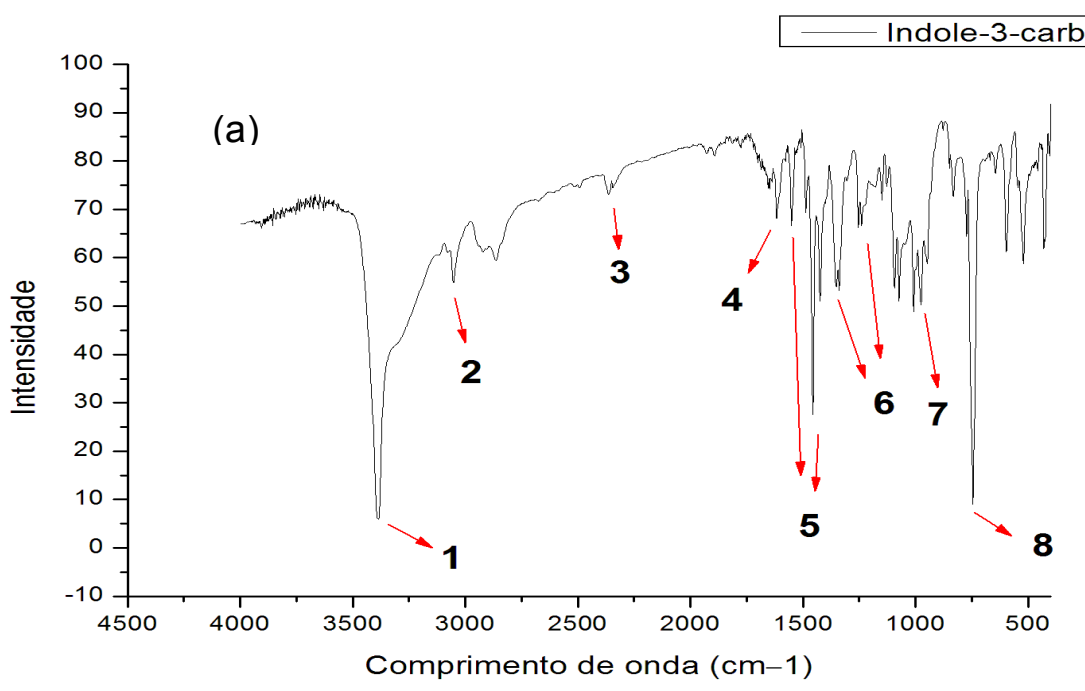

(c)<smiles>OCc1c[nH]c2ccccc12</smiles>

(b)

\begin{tabular}{|c|c|c|}
\hline $\mathbf{N}^{\mathbf{c}}$ & $\begin{array}{l}\text { Banda } \\
\text { absorção }\end{array}$ & Grupos funcionais \\
\hline 1 & $\sim 3390 \mathrm{~cm}^{-1}$ & $\mathrm{~N}-\mathrm{H}$ associado em aminas secundária \\
\hline 2 & $\sim 3050 \mathrm{~cm}^{-1}$ & C-H de anéis aromáticos \\
\hline 3 & $\sim 2370 \mathrm{~cm}^{-1}$ & Deformação angular de $\mathrm{N}-\mathrm{H}$ \\
\hline 4 & $\sim 1600 \mathrm{~cm}^{-1}$ & $\mathrm{C}=\mathrm{C}$ de anéis aromáticos \\
\hline 5 & $\sim 1580-1486 \mathrm{~cm}^{-1}$ & Deformação angular de N-H \\
\hline 6 & $\sim 1300-1200 \mathrm{~cm}^{-1}$ & Deformação angular de C-O \\
\hline 7 & $\sim 940 \mathrm{~cm}^{-1}$ & Deformação angular de $\mathrm{O}-\mathrm{H}$ \\
\hline 8 & $\sim 720 \mathrm{~cm}^{-1}$ & Deformação de $\mathrm{CH}_{2}$ \\
\hline
\end{tabular}

Figura 34. curva de espectrometria de infravermelho do fitoquimico indol-3-carbinol (a). Bandas de absorção dos espectro de infravermelho (b). Estrutura química do índole-3-carbinol (c).

A partir de amostras com diferentes teores de TEOS impregnados com I3C, segundo método de impregnação descrito na metodologia, mediram-se a absorbância na região de infravermelho registrados em $400 \mathrm{~cm}-1$ a $4500 \mathrm{~cm}-1$, foram nas mesma condições descritas acima.

A Figura 35 representam os espectros de infravermelho das amostras com 0, 12 e 50\% de TEOS sem impregnar (a), (b) e (c) e impregnadas (d), (e) e (f), respectivamente. Verifica-se a presença de uma banda de absorção, menos intensa, referente ao I3C nas amostras T0 e T12. Essa vibração na região de infravermelho registrado em torno de $2950 \mathrm{~cm}-1$, na Figura 35 (d), (e) e (f) é atribuída aos anéis aromáticos $\mathrm{C}-\mathrm{H}$ do I3C. 

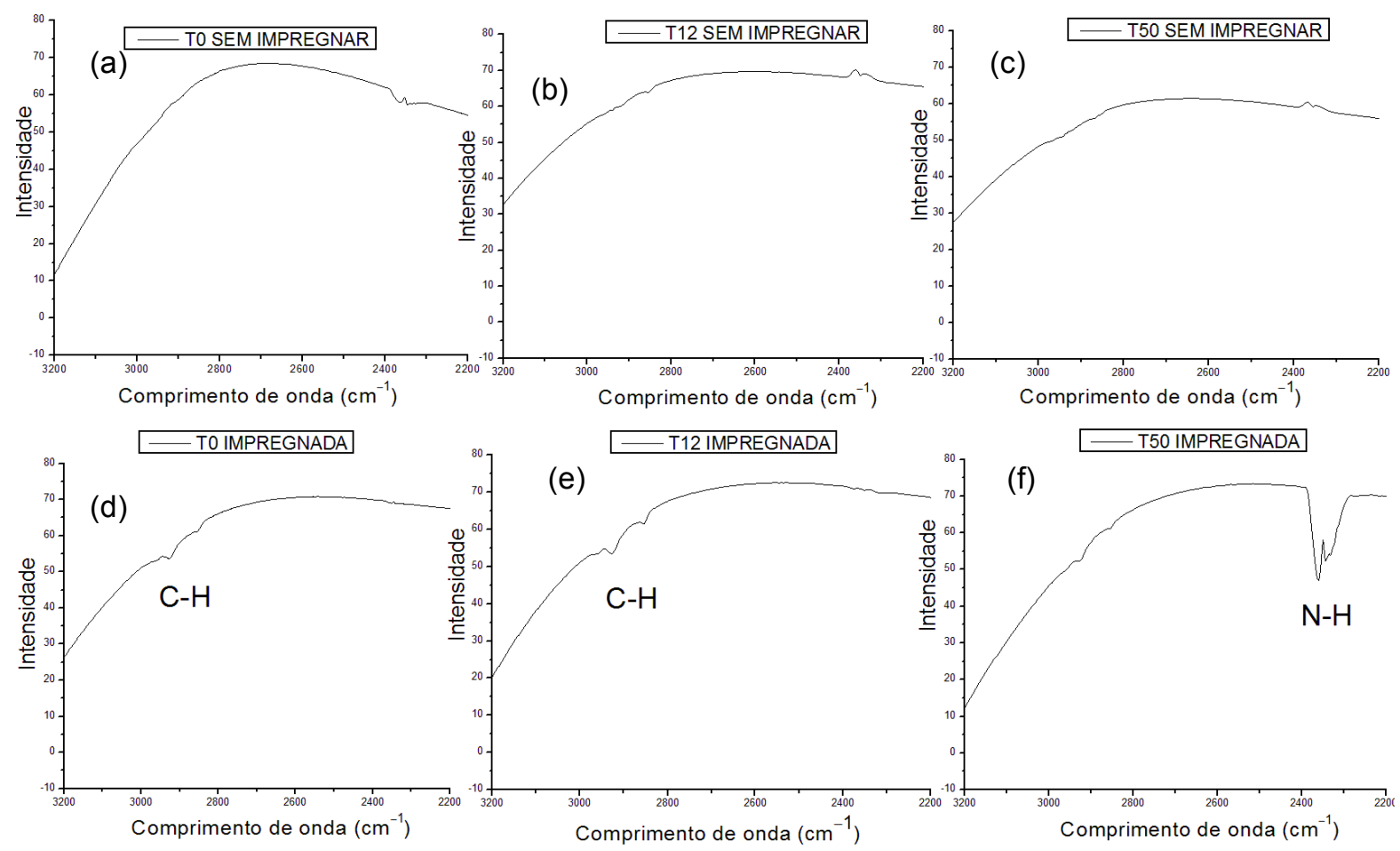

Figura 35. curva de espectrometria de infravermelho da amostra $T 0350^{\circ} \mathrm{C}$ pura em comparação com a amostra T0ag45h impregnada com indol-3-carbinol.

Já os espectros de infravermelho na Figura 35 (f) da amostra T50, revela uma banda de absorção adicional referente a deformação angular de $\mathrm{N}-\mathrm{H}$, centrado na região de absorção $2360 \mathrm{~cm}^{-1}$.

A Figura 36 apresenta três bandas de absorção que são características do fitoquímico I3C. Nota-se a presença dos anéis aromáticos da ligação $C=C$ centrado em $1600 \mathrm{~cm}-1$ e as deformações angulares de $\mathrm{N}-\mathrm{H}$ e C-O em torno de $1444 \mathrm{~cm}^{-1}$ e $1368 \mathrm{~cm}^{-1}$, respectivamente. 


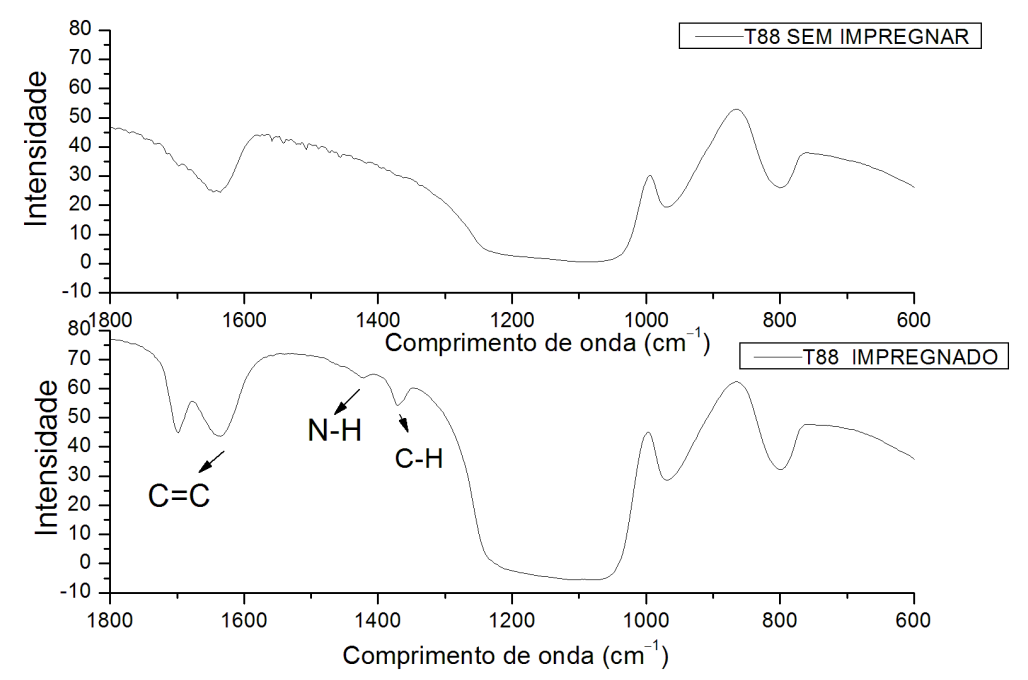

Figura 36. curva de espectrometria de infravermelho da amostra T88 pura em comparação com a amostra T88 impregnada com indol-3-carbinol.

Na Figura 37 observa-se as bandas de absorção do I3C na amostra T100 na região do espectro de infravermelho registrados em $1600 \mathrm{~cm}-1,1444 \mathrm{~cm}^{-1} \mathrm{e}$ $744 \mathrm{~cm}^{-1}$, que são atribuídas aos anéis aromáticos da ligação $\mathrm{C}=\mathrm{C}$ e as deformações angulares de $\mathrm{N}-\mathrm{H}$ e $\mathrm{CH}_{2}$, respectivamente.

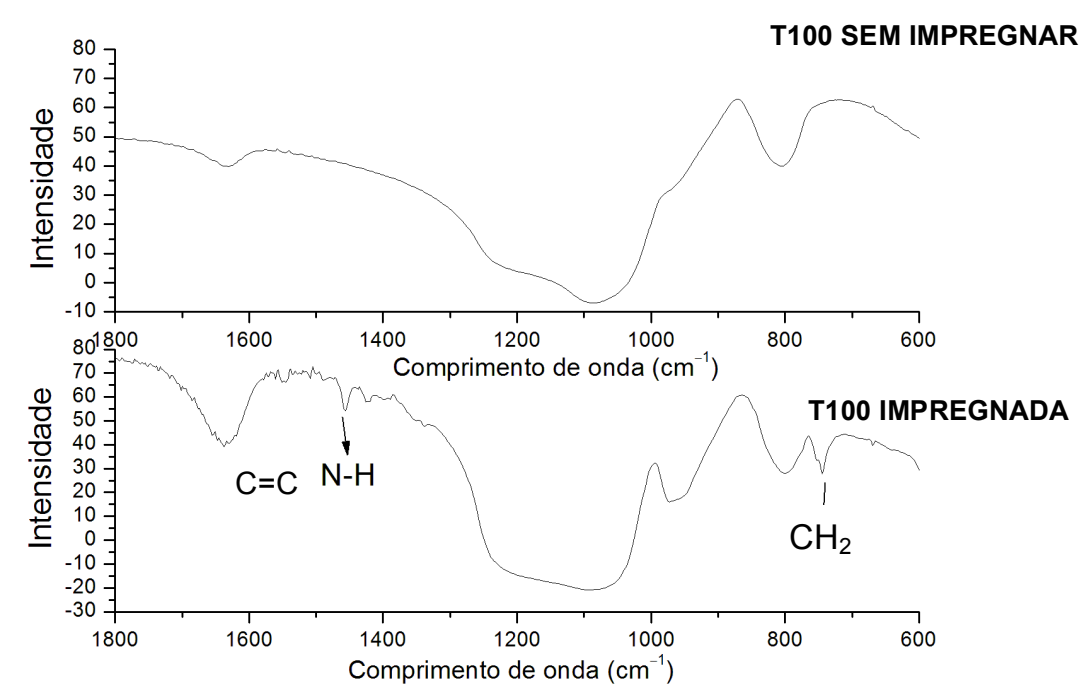

Figura 37. Curva de espectrometria de infravermelho da amostra T100 pura em comparação com a amostra T100 impregnada com indol-3-carbinol.

Os espectros das amostras apresentadas acima revelaram bandas de absorção com menor frequência e/ou intensidade. No entanto, é importante a 
realização de diferentes técnicas para confirmar a presença de compostos incorporados nas matrizes mesoporosas (GOBIN, 2006). Dessa forma, medidas de ressonância paramagnética eletrônica foram realizadas para verificar as interações e eficiência de impregnação dos materiais estudados.

As medidas de EPR das amostras calcinadas a $350^{\circ} \mathrm{C}$ por $10 \mathrm{~h}$ e impregnadas em forma de pó, foram feitas utilizando uma potência de microondas de $50 \mathrm{~mW}$ com uma frequência de $9,5 \mathrm{GHz}$. Os espectros de EPR das amostras estudadas estão representados na Figura 38 e foram registradas em um intervalo de campo magnético de -500 até 6500 Gauss.
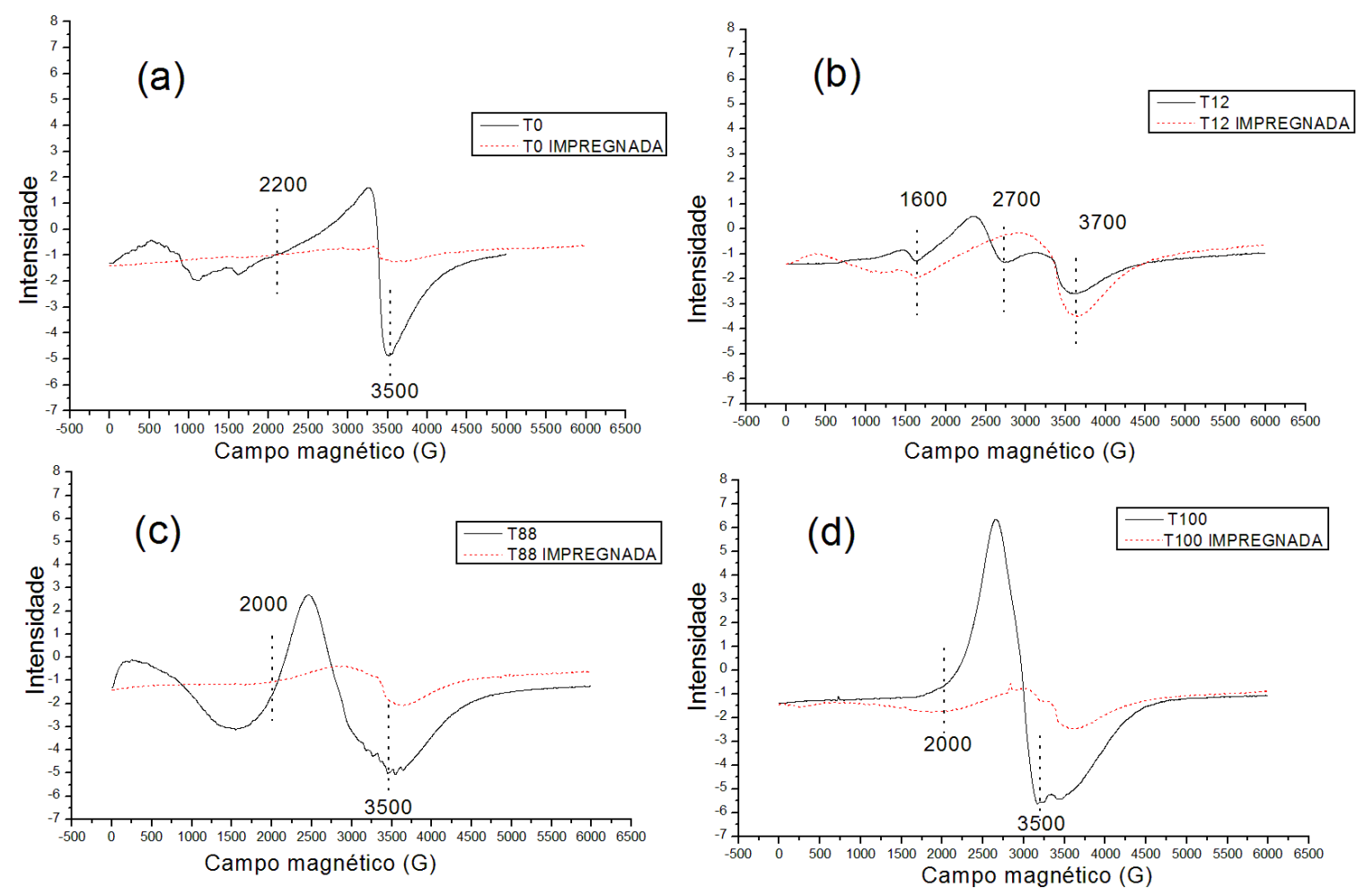

Figura 38. Espectros de ressonância paramagnética eletrônica das amostras T0, T12, T88 e $\mathrm{T} 100$ calcinadas a $350^{\circ} \mathrm{C}$ por 10 horas e calcinadas e impregnadas com $13 \mathrm{C}$ sob agitação por 45 horas.

$\mathrm{Na}$ Figura 38 (a) mostra o espectro de EPR do material T0 em comparação com a amostra impregnada T0 impregnada. Pode-se observar que amostra T0 impregnada apresenta um ponto de defeito de baixa intensidade centrada no campo magnético entre $2200 \mathrm{G}$ e $3500 \mathrm{G}$. Os espectros de EPR das amostras, T12, confrontada com a amostra, T12 impregnada, estão 
mostrados na Figura 38 (b). Nota-se no mesoporoso puro e calcinado, o ponto de defeito com intensidades semelhantes a amostra T12 impregnada, porém com deslocamento de Gauss de $1600 \mathrm{G}$ a $2700 \mathrm{G}$ para $3600 \mathrm{G}$.

Na Figura 38 (c) e (d) apresenta os espectros de EPR das amostras T88 e T100 sem I3C calcinadas a $350^{\circ} \mathrm{C}$ em comparação com os materiais T88 e T100 impregnados, respectivamente. Observa-se que a posição das linhas dos espectros de T88 e T100 foram parecidos e estão centrados entre 2000G e 3500G. Porém, com intensidades dos pontos de defeitos diferentes, sendo que a amostra com $100 \%$ de TEOS revelou um pico do ponto de defeito mais intenso. Verifica-se que as amostras impregnadas causaram uma supressão dos pontos de defeitos das amostras em impregnação.

Assim, como discutido e observado no estudo da impregnação, as medidas de espectrometria de infravermelho e ressonância paramagnética eletrônica sugerem a adsorção do I3C no interior dos silicatos de mesoporoso ou algum tipo de interação entre os grupos silanóis da superfície da sílica e os grupos funcionais da molécula de I3C.

A partir dos resultados encontrados, a fim de estimar a quantidade de $\mathrm{I} 3 \mathrm{C}$ impregnado nas amostras foi efetuada pelo método de análise indireta. $O$ sobrenadante foi coletado e analisado por UV-Vis com objetivo de quantificar o quanto sobrou do I3C não impregnado. Para calcular a concentração foram utilizados os valores de absorbância e a curva de calibração para o I3C, que serão apresentados a seguir no estudo de liberação. As fórmulas utilizadas para estimar a impregnação estão apresentadas na Equação (11).

$\mathrm{Na}$ Tabela 11 encontra-se os resultados valores estimados para a concentração do sobrenadante, do I3C impregnado e o percentual de impregnação das amostras. Pode-se observar que as amostras T100, T88 e T0 apresentaram valores percentuais similares em torno de $24 \%, 30 \%$ e $26 \%$, e maiores do que as amostras T50 e T12 com 17\% e 10\% de impregnação, respectivamente. De acordo com estes resultados, não foi possível correlacionar a quantidade impregnada com a porosidade dos mesoporosos estudados. 
Tabela 11. Estimativa da massa total de indol-3-carbinol contida no mesoporoso.

\begin{tabular}{|cccc|}
\hline Amostra & $\begin{array}{c}\text { Concentração do } \\
\text { sobrenadante }(\mathrm{mg})\end{array}$ & $\begin{array}{c}\text { Concentração de I3C nas } \\
\text { amostras }(\mathrm{mg})\end{array}$ & \% impregnado \\
\hline T100 & 7,5 & 2,5 & $24 \%$ \\
\hline T88 & 6,9 & 3,1 & $30 \%$ \\
\hline T50 & 8,3 & 1,7 & $17 \%$ \\
\hline T12 & 8,9 & 1,1 & $10 \%$ \\
\hline T0 & 7,4 & 2,6 & $26 \%$ \\
\hline
\end{tabular}

\subsection{Ensaio de liberação}

Os ensaios de liberação do fitoquímico a partir das sílicas elaboradas foram realizadas após a medida da curva de calibração do I3C. Obteve-se a curva de calibração partindo de diluições de uma solução estoque de concentração 0,002 mg/L em etanol, apresentada na Figura 39. O coeficiente angular expresso na curva de calibração foi de 52,62 e o coeficiente linear foi de 0 , 0067. O coeficiente de correlação ( $\mathrm{r} 2$ ) apresentou valor de 0,9884. Levando a construção da relação abaixo:

CONCENTRAÇÃO $(\mathrm{mg} / \mathrm{ml})$ = 0,0067 + Absorbância / 52,62

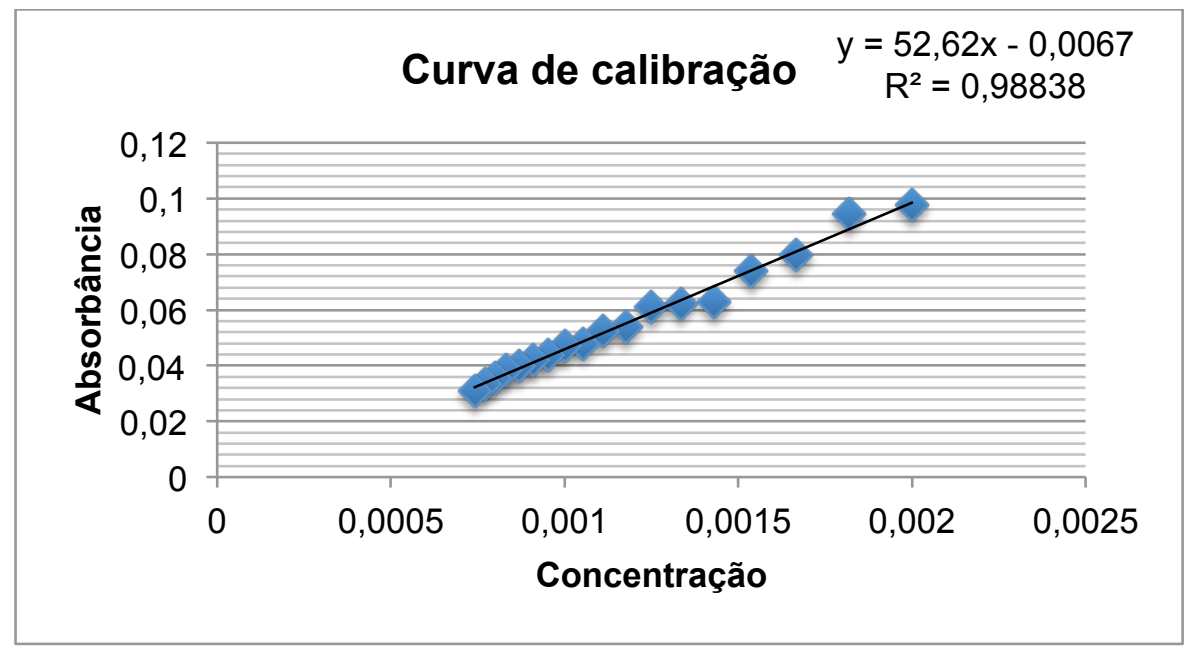

Figura 39 - Mostra a curva de calibração obtida a partir de diluições seriadas da solução estoque de I3C em concentração conhecida de $0,001 \mathrm{mg} / \mathrm{ml}$.

Após a curva de calibração foram realizados os cálculos descritos na metodologia para encontrar os percentuais de liberação das amostras. Os 
materiais obtidos T0, T12, T50, T88 e T100 foram medidos na região de absorbância a 279,5 nm pelo espectrofotômetro UV-Vis, em intervalos de tempo de 15 minutos por 45 horas.

A Figura 40 mostra o perfil de liberação das amostras impregnadas com 13C. Pode-se observar na Figura 40 que as amostras T0, T12, T50, T88 e T100 atingiram sua liberação máxima de $4 \%, 5,5 \%, 6 \%, 4,5 \%$ e $5 \%$ no período de $2,5,8,13$ e 24 horas, respectivamente. $O$ comportamento apresentado pelas amostras T0 e T12 pode ser atribuído a liberação as moléculas de I3C adsorvidas na superfície externa das partículas do material mesoporoso, dessa forma não sendo incorporado totalmente nos poros, ocasionando o fenômeno conhecido como burst release (liberação repentina ou abrupta) (SALONEN, 2005).

De acordo com alguns estudos a primeira fase de liberação corresponde à liberação das moléculas dispostas na superfície externa das nanopartículas, enquanto que a segunda fase de liberação corresponde à liberação sustentada das moléculas que adentraram aos poros (POPOVICl et. al., 2011). Verifica-se que o tempo de liberação está diretamente ligada as características da estrutura porosa obtidas no materiais estudados apresentados anteriormente na Tabela 9.

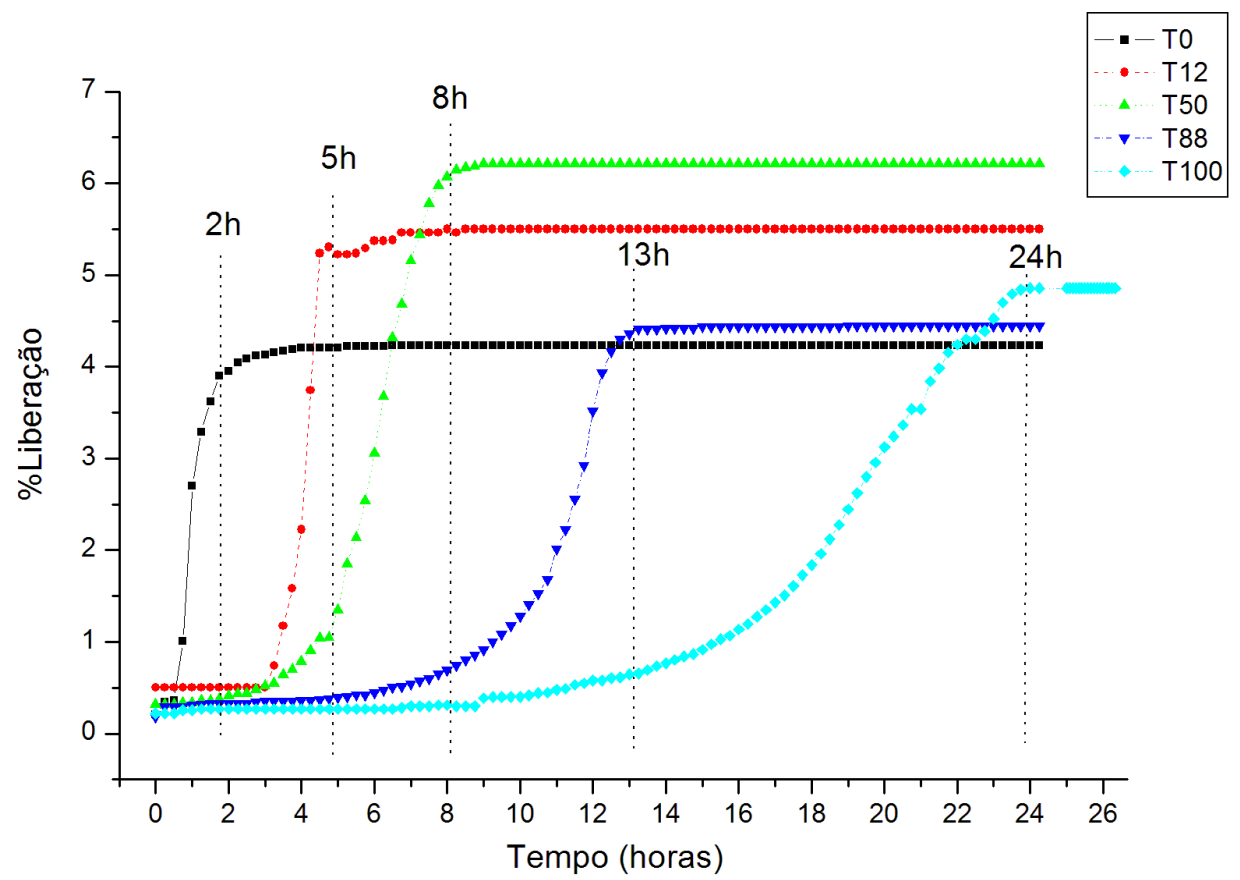

Figura 40. Ensaios de liberação de amostras impregnadas com diferentes porosidades. 
As amostras T50, T88 e T100 podem ser relacionadas com uma maior facilidade de difusão do $13 \mathrm{C}$, alguns trabalhos descrevem a liberação de compósitos ativos por matrizes do tipo SBA-15 (KRUK et al., 2000), presentes nas paredes da sílica na forma de canais interconectados entre si criando caminhos mais longos para a difusão do I3C (DOADRIO, 2004; MATOS et al., 2001).

Em outra direção, pode-se observar que a elevada área superficial das amostras T88 e T100 tiveram aumento exponencial da liberação do I3C que difere das amostras T0 e T12, o que corrobora com Vallet et al. (2008), que comparou a liberação sustentada de alendronato a partir mesoporosos do tipo MCM-41 e SBA-15. O MCM-41 apresentou uma área de superfície maior do que o tipo SBA-15 com uma liberação controlada mais eficiente.

Os perfis de liberação obtidos para as amostras avaliadas não foram semelhantes, diferenças podem ser atribuídas à área superficial da sílica do tipo SBA-16. Nota-se na Figura 40 que quanto maior a porosidade, maior a sustentação em horas do I3C liberado pelas matrizes mesoporosas. Deste modo, a impregnação do I3C em sílica do tipo SBA-16 originou um sistema de liberação modificada. Este sistema de difusão modificada para essa formulação 13C/mesoporoso, além de possibilitar a redução dos efeitos colaterais no tratamento do câncer pode fornecer maior proteção à molécula incorporada (SLOWING, 2006; LIONG, 2008; RIEHEMANN, 2009; HUANG, 2010). 


\section{CONCLUSÃO}

Os resultados deste trabalho mostraram que foi possível obter sílicas mesoporosas com uma estrutura de diferentes porosidades. A estratégia adotada para a síntese dos materiais com variadas áreas de superfície e diâmetro dos poros foi influenciada pelos teores de $0 \%, 12 \%, 50 \%, 88 \%$ e $100 \%$ de TEOS e silicato de sódio. A porosidade pode ser obtida após a desobstrução dos poros pela remoção do surfactante, através dos tratamento térmicos empregados a saber, $550^{\circ} \mathrm{C}$ e $450^{\circ} \mathrm{C}$ e $350^{\circ} \mathrm{C}$. A temperatura que apresentou maior vantagem em relação a remoção do surfactante e a porosidade foi a calcinação a $350^{\circ} \mathrm{C}$ por 10 horas. Além disso, a superfície especifica de BET (SBET) e o volume total de poros por unidade de massa da amostra diminuíram com tratamentos térmicos com temperaturas superior à $450^{\circ} \mathrm{C}$.

A variação da porosidade dos mesoporosos foi obtida com diferentes teores de TEOS e silicato de sódio, os quais mostraram ser eficazes na obtenção de diferentes áreas de superfície e diâmetro dos poros. Posteriormente, através do método de impregnação por ultrassom e agitação magnética, observou-se a incorporação do indol-3-carbinol nas amostras confirmado pela presença de bandas de absorção e diminuição de pontes defeito, pelos métodos de espectrometria de infravermelho e ressonância paramagnética eletrônica, respectivamente.

Ademais, as diferentes porosidades puderam ser correlacionadas com a liberação do ativo indol-3-carbinol. Verificou-se com o aumento dos teores TEOS na síntese do mesoporoso, uma área de superfície maior, com um tempo de liberação do bioativo $\mathrm{I} 3 \mathrm{C}$ por período prolongado de 24 horas. No entanto, são necessários estudos futuros com funcionalização das sílicas mesoporosos para aumentar o carregamento do I3C nas matrizes estudadas, e melhor compreensão e/ou otimização da liberação controlada.

Pode-se concluir que os mesoporosos de corpo centrado cúbico estudados, mostraram-se promissores para avanços dos tratamentos para o câncer entre outras patologias. Este material é capaz de induzir um dose reposta na faixa terapêutica de drogas e superar as barreiras do organismo e diminuir os efeitos colaterais. 


\section{Perspectivas futuras}

A fim de dar continuidade ao presente trabalho com objetivo de aprimorar o métodos de impregnação e sistemas liberação modificados pretende-se realizar as seguintes técnicas de analises e procedimentos:

-Análise de CHN para quantificar diretamente o carregamento do indol-3carbinol nas matrizes impregnadas;

-Funcionalização do mesoporoso a fim de aumentar o carregamento do indol-3carbinol nas matrizes;

-Análise de microscopia confocal para avaliar as interações dos mesoporosos puro e impregnado em células cancerígenas;

-Incoporação de outros fitoquímico e/ou nutrientes, tais com vitaminas, mineirais e fitoterápicos nas matrizes mesoporosas; 


\section{ANEXO 1}

Revisão bibliográfica da síntese do SBA-16.

\begin{tabular}{|c|c|c|c|c|c|}
\hline Autor & Ano & Tipo & Lavagem & Calcinação & Área e poro \\
\hline Jian Liu & 2007 & SBA-16 & $\begin{array}{l}200 \mathrm{~mL} \text { of etanol e } \\
1.5 \mathrm{~g} \text { of } \mathrm{HCl}(37 \\
\mathrm{wt} \%) \text { por } 24 \mathrm{~h}\end{array}$ & Sem calcinação & $\begin{array}{l}517-624 \mathrm{~m}^{2} / \mathrm{g} \\
10-16 \mathrm{~nm}\end{array}$ \\
\hline $\begin{array}{l}\text { Gracielle } \\
\text { Ferreira } \\
\text { Andrade }\end{array}$ & 2012 & SBA-16 & Sem lavagem & $\begin{array}{l}550^{\circ} \mathrm{C} \text { sob fluxo de } \\
\text { nitrogênio por } 5 \text { horas }\end{array}$ & $550 \mathrm{~m}^{2} / \mathrm{g}$ \\
\hline $\begin{array}{l}\text { Tae-Wan } \\
\text { Kim }\end{array}$ & 2012 & SBA-16 & $\begin{array}{l}\text { Lavagem com } \\
\text { etanol e seco a } \\
100^{\circ} \mathrm{C}\end{array}$ & Calcinado à $550^{\circ} \mathrm{C}$ & \\
\hline $\begin{array}{l}\text { Jeann Diniz } \\
\text { Ferreira } \\
\text { Lima }\end{array}$ & 2010 & SBA-16 & $\begin{array}{l}1,6150 \mathrm{~g} \text { do } 323 \mathrm{~mL} \\
\text { de etanol e } 6,46 \mathrm{~mL} \\
\text { de ácido clorídrico } \\
\text { de } 70 \mathrm{C} \text { e agitado - } \\
24 \mathrm{~h}\end{array}$ & $\begin{array}{l}350^{\circ} \mathrm{C} \text { com uma taxa de } \\
\text { aquecimento de } 3^{\circ} \mathrm{C} / \\
\text { minuto e sob fluxo de ar } \\
\text { durante } 4 \text { horas. }\end{array}$ & $\begin{array}{l}775 \mathrm{~m}^{2} / \mathrm{g} \\
7,81 \mathrm{~nm}\end{array}$ \\
\hline $\begin{array}{l}\text { Jeann Diniz } \\
\text { Ferreira } \\
\text { Lima }\end{array}$ & 2010 & SBA-16 & Sem lavagem & $\begin{array}{l}550^{\circ} \mathrm{C} \text { com uma taxa de } \\
\text { aquecimento de } \\
3^{\circ} \mathrm{C} / \text { minuto e sob fluxo } \\
\text { de ar durante } 4 \text { horas }\end{array}$ & $\begin{array}{l}620 \mathrm{~m}^{2} / \mathrm{g} \\
6,56 \mathrm{~nm}\end{array}$ \\
\hline $\begin{array}{l}\text { Monica } \\
\text { Mesa }\end{array}$ & 2005 & SBA-16 & Sem lavagem & $500^{\circ} \mathrm{C}$ por 3 horas & $\begin{array}{l}908 \mathrm{~m}^{2} / \mathrm{g} \\
6 \mathrm{~nm}\end{array}$ \\
\hline $\begin{array}{l}\text { Wesley J. J. } \\
\text { Stevens }\end{array}$ & 2006 & SBA-16 & $\begin{array}{l}3 \text { lavagens com } 25 \mathrm{~g} \\
\text { de } \mathrm{H}_{2} \mathrm{O}\end{array}$ & $\begin{array}{l}550^{\circ} \mathrm{C} \text { por } 6 \text { horas com } \\
\text { um taxa de } \\
\text { aquecimento de } \\
1^{\circ} \mathrm{C} / \text { minuto }\end{array}$ & $\begin{array}{l}989 \mathrm{~m}^{2} / \mathrm{g} \\
7 \mathrm{~nm}\end{array}$ \\
\hline $\begin{array}{l}\text { Tae-Wan } \\
\text { Kim }\end{array}$ & 2004 & SBA-16 & Sem lavagem & $500^{\circ} \mathrm{C}$ por 4 horas & $\begin{array}{l}819 \mathrm{~m}^{2} / \mathrm{g} \\
6,7 \mathrm{~nm}\end{array}$ \\
\hline
\end{tabular}




\section{REFERÊNCIAS}

Acharya, A, Das, I, Singh, Saha, S.T. Chemopreventive properties of índole-3carbinol, diindolymethane and other consituents of cardamom againt carcinogenesis. Recent Pat. Food Nutri. Agric. 2010; 2(2):166-177.

Ahmed, A, Boneer, C, Desai, T.A. Bioadhesive microdeviceswith multiple reservoirs: a new platform for oral drug delivery. Journal Controlled Release. 2002; 81(2):291-306.

Attard, G.S, Glyde, J. C, Goltner, C. G. Liquid-Crystalline Phases As Templates For The Synthesis Of Mesoporous Silica. Nature. 1995; 378(6555): 366-368.

Baker, R. Controlled release of biologically active agents. Willey Interscience. 1987; 77(4): 279.

Ballem, M.A, Córdoba, J.M, Odén, M. Influence of synthesis temperature on morphology of SBA-16 mesoporous materials with a three-dimensional pore system: Microporous and Mesoporous Materials. 2010; 129 (2): 106-111.

Balzer, R. Síntese e caracterização de catalisadores óxidos metálicos para oxidação catalítica total de BTX (benzeno, tolueno e orto-xileno) e transformação química de monoterpenos. Florianópolis. Tese (doutorado em Química) - Universidade Federal de Santa Catarina, Centro de Ciências Físicas e Matemáticas; 2014.

Barros, ALB et al. Synthesis, characterization, and biodistribution studies of 99mTc-labeled SBA-16 mesoporous silica nanoparticles. Materials Science and Engineering. 2015; 56(1):181-188.

Brevet, D, Gary-Bobo, M, Raehm, L, et al. Mannose targeted mesoporous silica nanoparticles for photodynamic therapy. Chem Commun. 2009;12(12):14751477.

Brinker, CJ. Sol-gel Science: The Physics and Chemistry of Sol-Gel Processing. (1 ed.). San Diego: 1990.

Cabral, P.A. Sistemas de Liberação Controlada de Drogas: Uma revisão. Minas Gerais. Monografia [Graduação em Medicina Veterinária] - Centro de Saúde e Tecnologia Rural, Universidade Federal de Campina Grande; 2004.

Cheng, C.F, Y.C, Lin, H.H, Cheng, Y.C, Chen. The effect and model of silica concentrations on physical properties and particle sizes of three-dimensional SBA-16 nanoporous materials. Chemical Physics Letters. 2003; 382(5-6): 496501.

Cheng, C.F, Lin, Y.C, Cheng, H.H, Liu, S.M, Sheu, H.S. Rapid crystallization of high quality cubic sillica SBA-16 nanoporous material. Chem. Lett. 2004; 33(3): 262-263. 
Chen, B.C, Chao, M.C, Lin, H.P, Mou, C.Y. Faceted single crystals of mesoporous SBA-16 from a ternary surfactant system: Surface roughening model. Microporous Mesoporous Mater. 2005; 81(1-3): 241-249.

Couderc, S. et al. Interaction between the Nonionic Surfactant Hexaethylene Glycol Mono-n-dodecyl Ether (C12EO6) and the Surface Active Nonionic ABA Block Copolymer Pluronic F127 (EO97PO69EO97)Formation of Mixed Micelles Studied Using Isothermal Titration Calorimetry and Differential Scanning Calorimetry. Langmuir. 2001; 17 (16), 4818-4824.

Crystal, N, Shyam, N, Min, Tseng, Antony, S, Kalvin, Q, Tran Kelly, M, Mahuron, Leonard Bjeldanes, F, Gary, F.L. Indole-3-carbinol downregulation of telomerase gene expression requires the inhibition of estrogen receptor-alpha and Sp1 transcription factor interactions within the hTERT promoter and mediates the G1 cell cycle arrest of human breast cancer cells. 2011; 32(9): 1315-1323.

De Alemida, V.L. et al. Cancer and cell cicle-specific and cell cicle nonspecific anticancer DNA-interactive agents: An introduction. Química Nova. 2005; 28(1): 118-129.

De Azevedo, M.M. Sistemas poliméricos de liberação controlada utilizando micro e nanopartículas encapsulando violaceína: caracterização, atividade biológica, conseqüências e perspectivas. São Paulo. Tese [Doutourado em ciências] - Universidade Estadual de Campinas, Instituto de Química; 2005.

Doadrio, A.L, et al. Mesoporous SBA-15 HPLC evaluation for controlled gentamicin drug delivery. Journal of Controlled Release. 2004; 97(1):125-132.

Escobar, C.J, López, C.J, Naik, M.A. Applications of thermoreversible pluronic F-127 gels in pharmaceutical formulations. Pharm. Pharmaceut. 2006; 9(3): 39358.

Farrell, D, Ptak, K, Panaro, N.J, Grodzinski, P. Nanotechnology-based cancer therapeutics-promise and challenge-lessons learned through the $\mathrm{NCl}$ Alliance for Nanotechnology in Cancer. Pharm Res. 2011; 28 (2):273-8.

Ferris, DP, Lu, J, Gothard, C, et al. Synthesis of biomolecule-modified mesoporous silica nanoparticles for targeted hydrophobic drug delivery to cancer cells. Small. 2011; 7(3):1816-1826.

Fujiwara, M, Mal, N.K, Tanaka, Y. Photocontrolled reversible release of guest molecules from coumarin-modified mesoporous silica. Nature. 2003; 421(6921): 350-353.

Galarneau, A, Cambon, N, Di Renzo, F. Microporosity and connections between pores in sba-15 mesostructured silicas as a function of the temperature of synthesis. New Journaul of chemistry. 2003; 27(1): 73-79.

Gao, F, Botella, P, Corma, A, Blesa, J, Dong, L. Monodispersed mesoporous 
silica nanoparticles with very large pores for enhanced adsorption and release of DNA. J Phys Chem B. 2009; 113(6):1796-804.

Gary-Bobo, M, Mir, Y, Rouxel, C, et al. Mannose-functionalized mesoporous silica nanoparticles for efficient two-photon photodynamic therapy of solid tumors. Angew Chem Int Ed. 2011; 50(48):11425-9.

Gobin, O.C. SBA-16 Materials Synthesis, Diffusion and Sorption Properties. Canada. Laval University; 2006.

Greccol, T, Rangell, M.C, Gonzálezll, E.A.U. Zeólitas hierarquicamente estruturadas. Quím. Nova 2013; 36(1): 1-12.

Gregg, S.J, Sing, K.S. Adsorption, Surface area and Porosity. (2 ed.). London: Academic Press; 1982.

Grudzien, R.M, Grabicka, B.E, Jaroniec, M. Efective method to removal of polymeric template from SBA-16 silica combining extraction and temperaturecontrolled calcinations. J. Mater. Chem. 2006a; 16(9): 819-823.

Grudzien, R.M, Pikus, S, Jaroniec, M. Periodic mesoporous organosilicas with Im3m symmetry and large isocyanurate bridging groups. J. Phys. Chem. B: Lett. 2006b;110(7):2972-2975.

Hanahan, D, Weinberg, R. A. Hallmarks of cancer: the next generation. Cell. 2011;144(5):646-74.

Hareesh, B, Nair, A, Bokyung, Sung, B, Vivek, R, Yadav B, Ramaswamy Kannappan B, Madan M, Chaturvedi B, Bharat B, Aggarwal B. Delivery of antiinflammatory nutraceuticals by nanoparticles for the prevention and treatment of cancer. Biochem Pharmacol. 2010; 80(12):1833-43.

He, Q, Zhang, J, Shi, J, Zhu, Z, Zhang, L, Bu, W, et al. The effect of PEGylation of mesoporous silica nanoparticles on nonspecific binding of serum proteins and cellular responses. Biomaterials. 2010;31(8):1085-92.

$\mathrm{He}, \mathrm{Q}$, Zhang, Z, Gao, F, Li, Y, Shi, J. In vivo biodistribution and urinary excretion of mesoporous silica nanoparticles: effects of particle size and PEGylation. Small. 2011;7(2):271-280.

Hench, L.L, West, K.J. The sol-gel process. Chem. Rev. 1990; 90(1): 33-72.

Hozumi, A, Yokogawa, Y, Kameyama, T, Hiraku, K, Sugimura, H,Takai, O, Okido, M. Photocalcination of mesoporous silica films using vacuum ultraviolet light. Adv. Mater. 2000, 12:985-987.

Huang, L, Poh, C, Ng, S.C, Hidajat, K, Kawi, S. Preparation of supported mesoporous thin films concerning template removal by supercritical fluid extraction. Langmuir. 2005, 21(4): 1171-1174. 
Huang, $\mathrm{Q}, \mathrm{Yu}, \mathrm{H}, \mathrm{Ru}, \mathrm{Q}$. Bioavailability and delivery of nutraceuticals using nanotechnology. J Food Sci. 2010; 80(12):1833-43.

Huo, Q.S, Margolese, D.I, Ciesla, U., Feng, P.Y, Gier, T.E, Sieger, P, Leon, R, Petroff, P.M, Schuth, F, Stucky, G.D. Generalized synthesis of periodic surfactant/inorganic composite materials. Nature. 1994; 368: 317-321.

Hu, Y.Z, Zhi, Q, Zhao, C, Wu, P, Zhao, H, Jiang, T, Jiang S. Wang. 3D cubic mesoporous silica microsphere as a carrier for poorly soluble drug carvedilol. Microporous and Mesoporous Materials. 2012; 147(1):94-101.

He, Q, Shi, J. Mesoporous silica nanoparticle based nano drug delivery systems: synthesis, controlled drug release and delivery, pharmacokinetics and biocompatibility. J. Mater. Chem. 2011; 21(8): 5845-5855.

He, Q, Zhang, J, Chen, F, Guo, L, Zhu, Z, Shi, J. An anti-ROS/hepatic fibrosis drug delivery system based on salvianolic acid $B$ loaded mesoporous silica nanoparticles. Biomaterials. 2010; 31(30):7785-96.

Higuchi, T. Mechanism of sustained-action medication. Theoretical analysis of rate of release of solid drugs dispersed in solid matrices. J. Pharm. Sci. 1963; 52:1145-1149.

Humphrey, H.P.Y, Wright, P.A, Enzymes supported on ordered mesoporous solids: a special case of an inorganic-organic hybrid. 2005;15(35-36):36903700 .

Hynes, D, M, Weaver, F, Morrow, et al. Breast cancer surgery trends and outcomes: results from a national department of veterans affairs study. J Am Coll Surg. 2004.198(5):707-16.

INCA (Instituto Nacional de Câncer do Brasil). Ministério da Saúde. Situação do Câncer no Brasil - 2012 . Disponível em: http://www.inca.gov.br/estimativa/2012/, acessado em 18 de fevereiro de 2013.

Liong, M, Lu, J, Kovochich, M, et al. Multifunctional inorganic nanoparticles for imaging, targeting, and drug delivery. ACS Nano. 2008; 2(5):889-896.

Kleitz, F, Kim, T.W, Ryoo, R. Phase domain of the cubic Im3m mesoporous silica in the EO106PO70EO106-Butanol-H2O system. Langmuir. 2006; 22(1): 440-445.

Kresge, C.T, Leonowicz, M.E, Roth, W.J, Vartuil, J.C, Beck, J.S. Ordered mesoporous molecular sieves synthesized by a liquid-crystal template mechanism. Nature. 1992; 359:710-712.

Kruk, M, Jaroniec, M, Ko, C.H, Ryoo, R. Characterization of the porous structure of SBA-15. Chem. Mater. 2000;12(7):1961-1968.

Langer, R. New methods of drugs delivery. Science. 1990; 249(4976):15271533. 
Lee, C.H, Cheng, S.H, Huang, I.P. Intracellular pH-responsive mesoporous silica nanoparticles for the controlled release of anticancer chemotherapeutics. Angew Chem Int Ed. 2010;49(44):8214-8219.

Lehninger, A.L, Nelson D.L, Cox M.M, Principles of Biochemistry, 3.ed.: New York: Worth Publisnhing; 2000.

Li, D, Guan, X, Song, J, Di, Y, Zhang, D, Ge, X, Zhao, L, Xiao, F.H. Highly efficient synthesis of ordered mesoporous silica materials with controllable microporosity using surfactant mixtures as templates. Colloid Surface A: Physicochem. Eng. Aspect. 2006; 272(3):194-202.

Lima, J.D.F. Obtenção de sílicas mesoporosas SBA-15 e SBA-16 com poros grandes. Ceará. Monografia [graduação em química] - Universidade Federal do Ceará, departamento de Engenharia Química; 2010.

Lin, C.L. et al. Synthesis of SBA-16 and SBA-15 mesoporous silica crystal templated with neutral block copolymer surfactants. J. Phys. Chem. Solids 2008; 69(2-3): 415-419.

Lin, Y. et al. A mesoporous silica nanosphere-based carrier system with chemically removable CdS nanoparticle caps for stimuli-responsive controlled release of neurotransmitters and drug molecules. Journal American Chemistry Society. 2003; 125(15):4451.

Lin, Y.S, Haynes, C.L. Impacts of mesoporous silica nanoparticle size, pore ordering, and pore integrity on hemolytic activity. $J$ Am Chem Soc. 2010;132(13):4834-42.

Liong, M, Lu, J, Kovochich M, et al. Multifunctional inorganic nanoparticles for imaging, targeting, and drug delivery. ACS Nano. 2008;2(5):889-896.

Liu et al. Pore size control of mesoporous silicas from mixtures of sodium silicate and TEOS. Microporous and Mesoporous Material. 2007; 106(1-3) 6267.

Lu, J, Liong, M, Zink, J.I, Tamanoi, F. Mesoporous silica nanoparticles as a delivery. Small. 2007;3(8):1341-1346.

Lubet, R.A, Heckman B.M, De Flora, S.L, Steele, V.E, Crowell, J.A, Juliana, M.M, Grubbs C.J. Effects of 5,6-benzoflavone, indole-3-carbinol and diindolylmethane on chemically-induced mammary carcionogesis: Is DIM a substitute for I3C?. Oncol. Rep. 2011; 26(3):731-6.

Manada et al. A dissolução in vitro na previsão da absorção oral de fármacos em formas farmacêuticas de liberação modificada. Revista Brasileira de Ciências Farmacêuticas. 2002; 38(2): 29-35. 
Marconett, C.N, Singhal, A.K, Sundar, S.N, Firestone, G.L. Indole-3-carbinol disrupts estrogen receptor-alpha dependent expression of insulin-like growth factor-1 receptor and insulin receptor substrate-1 and proliferation of human breast cancer cells. Mol Cell Endocrinol. 2012;363(1-2):74-84.

Matos, J.R, Mercuril, L.P, Kruk, M, Jaroniec, M. Toward the synthesis of extralarge-pore MCM-41 analogues. Chemistry of Materials. 2001;13(2):1726-1731.

Meng $\mathrm{H}$, Xue, $\mathrm{M}$, Xia, $\mathrm{T}$, et al. Autonomous in vitro anticancer drug release from mesoporous silica nanoparticles by $\mathrm{pH}$-sensing nanovalves. J Am Chem Soc. 2010;132(36):12690-12697.

Meng, $\mathrm{H}$, Xue, M, Xia, T, et al. Use of size and a copolymer design feature to improve. Acs Nano. 2011;5(5):4131-4144.

Mesa, M, Sierra, L, Patarin, J, Guth, J.L. Morphology and porosity characteristics control of SBA-16 mesoporous silica. Effect of the triblock surfactant Pluronic F127 degradation during the synthesis. Solid State Sci. 2005; 7(8): 990-997.

Mesa, M, Sierra, L, Guth, J.L. Contribution to the study of the formation mechanism of mesoporous SBA-15 and SBA-16 type silica particles in aqueous acid solutions. Microporous Mesoporous Mater. 2008; 112, 338-350.

Meynen, V, Cool, P. Vansant, E.F. Verified syntheses of mesoporous materials. Microporous and Mesoporous Materials. 2009;125 (3):170-223.

Nair, HB, Sung, B, Yadav, V.R, Kannappan, R, Chaturvedi, M.M, Aggarwal, B.B. Delivery of antiinflammatory nutraceuticals by nanoparticles for the prevention and treatment of cancer. Biochem Pharmacol. 2010; 80(12):183343.

Orlikova, B, Diederich, M. Power from the garden: plant compounds as inhibitors of the hallmarks of cancer. Curr Med Chem. 2012;19(14):2061-87.

Popovici, R.F. et al. Controlled Drug Delivery System Based on Ordered Mesoporous Silica Matrices of Captopril as Angiotensine- Converting Enzyme Inhibitor Drug. Journal of Pharmaceutical Sciences, Roménia, fev. 2011; 100(2): 704-714.

Qian, X, Melkamu, T, Upadhyaya P, Kassie, F. Indole-3-carbinol inhibited tobacco smoke carcionogen-induced lung adenorcinoma in $A / J$ mice when administered during the pos-initiation or progression phase of lung tumorigenesis. Cancer Lett. 2011; 311(1):57-65.

Riehemann, K, Schneider, S.W, Luger, T.A, Godin, B, Ferrari, M, Fuchs, H. Nanomedicine--challenge and perspectives. Angew Chem Int Ed Engl. 2009;48(5):872-97. 
Ritger, P.L, \& Peppas, N.A. A simple equation for description of solute release II. Fickian and anomalous release from swellable devices. Journal of Controlled Release. 1987;5(1):37-42.

Rouzaud, G, Young S.A, Duncan A.J. Hydrolysis of glucosinolates to isothiocyanates after ingestion of raw or microwaved cabbage by human volunteers. Cancer Epidemiol Biomarkers Prev. 2004;13(1):125-131.

Salonen, J, et al. Mesoporous silicon microparticles for oral drug delivery: Loading and release of five model drugs. Journal of Controlled Release, 2005; 108(2-3):362-374.

Shah, TA. Direct synthesis of mesoporous molecular sieves of Ni-SBA-16 by internal $\mathrm{pH}$ adjustment method and its performance for adsorption of toxic Brilliant Green dye. 2015; 8(4): 579-586.

Shaikh, J, Ankola, DD, Beniwal, V, Singh, D and Kumar, MN. Nanoparticle encapsulation improves oral bioavailability of curcumin by at least 9-fold when compared to curcumin administered with piperine as absorption enhancer. Eur $\mathrm{J}$ Pharm Sci. 2009;37(3-4): 223-230.

Shapiro, T.A, Fahey, J.W, Wade, K.L, Stephenson, K.K, Talalay P. Chemoprotective glucosinolates and isothiocyanates of broccoli sprouts: metabolism and excretion in humans. Cancer Epidemiol Biomarkers Prev. 2001;10(5):501-508.

Sherrill, L, Macura, Jeremy, L, Steinbacher et al. Microspheres targeted with a mesothelin antibody and loaded with doxorubicin reduce tumor volume of human mesotheliomas in xenografts. Int J Nanomedicine. 2013;7(13):5119-28.

Silverman, R.B, Mark, M.W. The Organic Chemistry of Drug Design and Drug Action. (3nd ed.). San Diego: Elsevier; 1992.

Slowing, I.I, Trewyn, B.G, Lin, V.S. Effect of surface functionalization of MCM41-type mesoporous silica nanoparticles on the endocytosis by human cancer cells. J Am Chem Soc. 2006;12(8):14792-14793.

Slowing, I.I, Vivero-Escoto, J.L, Wu, C.W, Lin, V.S. Mesoporous silica nanoparticles as controlled release drug delivery and gene transfection carriers. Adv Drug Deliv Rev. 2008; 60(11):1278-1288.

Srinivas, P.R, Philbert M, Vu, T.Q, Huang, Q, Kokini, J.L, Saos E, Chen H, Peterson C.M, Friedl K.E, McDade-Ngutter C, Hubbard V, Starke-Reed P, Miller N, Betz J.M, Dwyer J, Milner J, Ross SA. Nanotechnology Research: Applications in Nutritional Sciences. The Journal of Nutrition. 2010; 140(1): 119124.

Stucky, G.D et al.. Synthesis Of Highly Ordered Mesoporous Silica Materials Using Sodium Silicate And Amphiphilic Block Copolymers. Chemical communications. 2000; 2362(13):1159-1160. 
Tian, B, Liu, X, Yu, C, Gao, F, Luo, Q, Xie, S, Tu B, Zhao, D. Microwave assisted template removal of siliceous porous materials. Chem. Commun. 2002; $7(11): 1186-1187$.

Vallet, M, Ramila, A, Real, R. P. A New Property of MCM-41: Drug Delivery System. Chemitry of Materials, 2004; 13():308-311.

Vallet, M.et. al. Functionalization of mesoporous materials with long alkyl chains as a strategy for controlling drug delivery pattern. Journal of Materials Chemistry. 2006;16 (2):462-466.

Vallet, M.et. al. MCM-41 Organic Modification as Drug Delivery Rate Regulator. Chemitry of Materials, 2007a; 15 (2): 500-5.

Vallet, M, et al. Bioceramics and pharmaceuticals: A remarkable synergy, Solid State Sciences. 2007b;9(9) , p.768-776.

Vallet, M.et. al. Functionalization degree of SBA-15 as key factor to modulate sodium alendronate dosage. Microporous and Mesoporous Materials. 2008; $116(1-3): 4-13$.

Voort, P.V, Benjelloun, M, Vansant, E.F. Rationalization of the Synthesis of SBA-16: Controlling the Micro- and Mesoporosity. J. Phys. Chem. B. 2002;106(35):9027.

Wang, T.T, Schoene, N.W, Milner, J.A, Kim, Y.S. Broccoli-derived phytochemicals indole-3-carbinol and 3,3-diindolylmethane (DIM) exerts concentration-dependent pleiotropic effects on prostate cancer cells: Comparison with other cancer preventive phytochemicals. Mol. Carciog. 2012;51(3):244-56.

Wang, H, Khor T.O, Shu, L, Su, Z.Y, Fuentes F, Lee J.H, Kong A.N. Plants vs. Cancer: A review on Natural Phytochemical in preventing and Treating cancers and thei druggability. Anticancer Agents Med Chem. 2012;12(10):1281-305.

Wang, Y, Zhao, D. On the controllable soft-templating approach to mesoporous silicates. Chem. Rev. 2007; 107(7):2821-2860.

Yang, C.M, Zibrowius, B, Schmidt, W, Schuth, F. Consecutive generation of mesopores and micropores in SBA-15. Chem. Mater. 2003; 15(20); 3739-3741.

Yang, C.M, Schmidt, W, Kleitz, F. Pore topology control of three-dimensional large pore cubic silica mesophases. J. Mater. Chem. 2005; 15(48): 5112-5114.

Zhao, D, Huo, Q, Feng, J, Chmelka, B.F, Stucky, G.D. Nonionic triblock and star diblock copolymer and oligomeric surfactant synthesis of highly ordered, hydrothermally stable, mesoporous silica structures. J. Am. Chem. Soc. 1998; 120 (24):6024-6036. 
Zhao, D, Feng, J, Huo, Q. Triblock Copolymer Syntheses of Mesoporous Silica with Periodic 50 to 300 angstrom Pores. Science. 1998;279(5350): 548-552.

Zhao, Y, Li, Z, Kabehie, S, Bostros, Y.Y, Stoddart, J.F. PH-operated nanopistons on the surfaces of mesoporous silica nanoparticles. J Am Chem Soc. 2010;132(37): 13016-13025.

Zhoa, X. S, Chong, A. S. M, Kustedjo, A. T, Qiao, S. Z. Functionalization of large-pore mesoporous silicas with organosilanes by direct synthesis. Microporous and Mesoporous Materials. 2004; 72(1-3)33-42. 